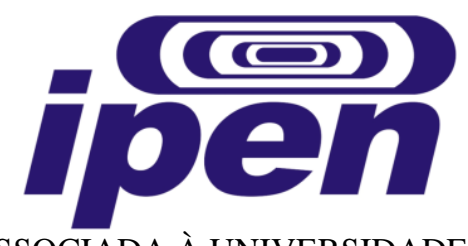

AUTARQUIA ASSOCIADA À UNIVERSIDADE DE SÃO PAULO

\title{
CRESCIMENTO DE GRÃOS E CONDUTIVIDADE ELÉTRICA DA CÉRIA-SAMÁRIA USANDO O MÉTODO DE SINTERIZAÇÃO EM DUAS ETAPAS
}

SHIRLEY LEITE DOS REIS

Dissertação apresentada como parte dos requisitos para obtenção do Grau de Mestre em Ciências na Área de Tecnologia Nuclear - Materiais Orientadora:

Profa. Dra. Eliana Navarro dos Santos Muccillo 
Aे Deus

E a minha mãe, Cida 
Porque é necessário perseverar, para que, havendo feito a vontade de Deus, alcanceis a promessa. Hebreus 10:36. 


\section{Agradecimentos}

Gostaria de agradecer...

primeiramente a Deus, pelo cuidado tão especial comigo,

à minha orientadora, Dra . Eliana N. S. Muccillo, pela dedicada orientação, apoio, incentivo e confiança.

ao Dr. Reginaldo Muccillo pelos ensinamentos,

ao CNPq pela bolsa de mestrado concedida,

ao IPEN pela oportunidade de realizar esse trabalho,

a Yone V. França, por estar sempre cuidando do laboratório,

a Dra. Eliana Aricó pelas medidas de Dilatometria,

ao Dr. Valter Ussui pelas medidas de BET,

a minha mãe que é a uma benção em minha vida e que sempre cuidou, orou, ensinou e me incentivou,

a todos aqueles que oraram por mim durante esse meu trabalho, especialmente ao pessoal da minha igreja,

ao Charles, um grande amigo que conquistei no inicio desse mestrado e que desde então me incentivou, ajudou e contribuiu muito em minha vida.

Não poderia deixar de agradecer a minha grande amiga Leticia Lopes que desde a graduação me aguenta.

a todos os amigos que conquistei e que sempre me apoiaram nos meus estudos.

a toda minha família que está sempre ao meu lado,

ao pessoal do CCTM que contribuíram direta e indiretamente nesse trabalho, Dra. Renata Ayres, Dra. Erica Caproni, Dr. Eduardo Caetano, Dr. Ariston Junior, Dr. Fabio Camargo, Dra. Eduarda Maria Tomas,

e aos colegas que fizeram com que esse período fosse muito agradável, Graziela Telles, Tatiane Porfírio, Olavo Rodrigues, Rafael Morgado, João Roberto, Tiago Andrade, Karina M. Mano, Andressa Ferreira, Renata Bressane,

e aos membros da banca pelas contribuições nesse trabalho, Prof. Dr. Samuel Toffoli e Prof. Dr. Luis Antonio Genôva. 


\title{
CRESCIMENTO DE GRÃOS E CONDUTIVIDADE ELÉTRICA DA CÉRIA-SAMÁRIA USANDO O MÉTODO DE SINTERIZAÇÃO EM DUAS ETAPAS
}

\author{
Shirley Leite dos Reis
}

\begin{abstract}
Resumo
A solução sólida céria-samária é uma das principais candidatas para aplicação como eletrólito sólido em células a combustível de óxido sólido, devido sua alta condutividade iônica em temperaturas intermediárias $(500-750 \stackrel{\circ}{C})$ de operação. Um dos problemas ainda não solucionados com relação a este material é sua relativamente baixa sinterabilidade. Nesse trabalho foi utilizado o método de sinterização em duas etapas visando melhorar a densificação com reduzido tamanho médio de grãos. Soluções sólidas comercial e obtida por mistura de óxidos de composição $\mathrm{Ce}_{0,8} \mathrm{Sm}_{0,2} \mathrm{O}_{1,9}$ foram utilizadas. Para fins comparativos também foi utilizado o método denominado sinterização em duas etapas "tradicional" que visa a obtenção de amostras densas independentemente do tamanho médio de grãos. Resultados de densidade aparente e retração linear revelaram que ambos os tipos de amostras têm comportamento distinto. Para a solução sólida comercial, a retração total até $1400 \stackrel{\circ}{\mathrm{C}}$ foi de $\sim 18 \%$. Só foram obtidos resultados de densidade significativos ao utilizar temperaturas elevadas (igual ou superior a $1300^{\circ} \mathrm{C}$ ). Para o material obtido por mistura de óxidos não foi possível atingir densidades maiores que $90 \%$ da densidade teórica. A sinterização em duas etapas tradicional produziu amostras densas, da mesma forma, que a não-tradicional, mas com tamanhos de grãos consideravelmente maiores. Amostras sinterizadas por ambos os processos foram analisadas por espectroscopia de impedância para a determinação da condutividade elétrica em função da temperatura, e não apresentaram variação significativa nas condutividades intra e intergranular. A sinterização em duas etapas não resultou em melhorias na densificação e nem na condutividade elétrica das amostras. Entretanto, a redução obtida no tamanho médio de grãos pode melhorar as propriedades mecânicas.

Palavras-chave: Sinterização, céria-samária, tamanho de grão, condutividade elétrica.
\end{abstract}




\title{
GRAIN GROWTH AND ELECTRICAL CONDUCTIVITY OF SAMARIA-DOPED CERIA SINTERED BY THE TWO-STEP SINTERING METHOD
}

\author{
Shirley Leite dos Reis
}

\begin{abstract}
Samaria-doped ceria solid solution has been proposed to be used as solid electrolyte in Solid Oxide Fuel Cells due to its high ionic conductivity at intermediate temperatures $\left(500-750^{\circ} \mathrm{C}\right)$. One of the main problems related to this solid solution is the relatively low sinterability. In this work, sintering of powder compacts was carried out by the two-step sintering method to improve the densification with simultaneous reduction of the mean grain size. Samariadoped ceria, both commercial and prepared by solid state reactions, with composition $\mathrm{Ce}_{0.8} \mathrm{Sm}_{0.2} \mathrm{O}_{1.9}$ were investigated. For comparison purposes, the traditional two-step sintering method, by which dense specimens are produced, was also utilized. Apparent density and linear shrinkage results showed distinct features depending on the type of specimen. Total linear shrinkage for commercial solid solution up to $1400 \stackrel{\circ}{\circ}$ was $18 \%$, but high density values were obtained only for sintering experiments conducted at high temperatures ( $\geq$

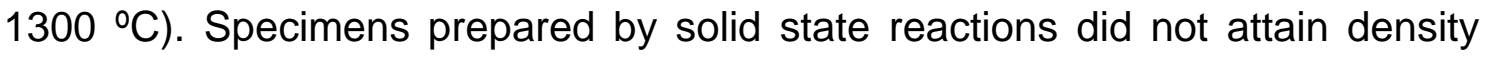
values higher than $90 \%$ of the theoretical one. The traditional method produced dense specimens as well as the two-step sintering, although the grain size was considerably higher in the former. Specimens sintered by the two methods were used for electrical conductivity measurements. No significant variation in both the grain and the grain boundary conductivities was obtained. The two-step sintering did not allow any improvement in the densification and in the electrical conductivity of samaria-doped ceria. However, the decrease in the mean grain size may contribute to improve the mechanical properties of this solid solution.
\end{abstract}

Keywords: Sintering, samaria-doped ceria, grain size, electrical conductivity. 


\section{Índice}

Página

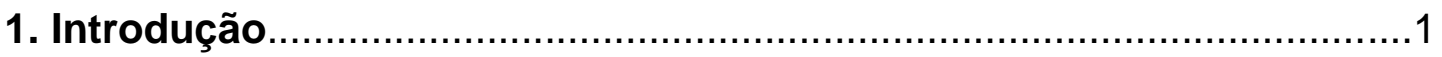

2. Fundamentos teóricos....................................................................

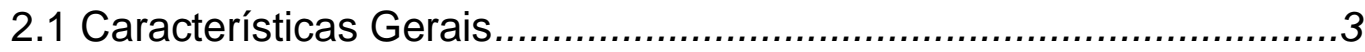

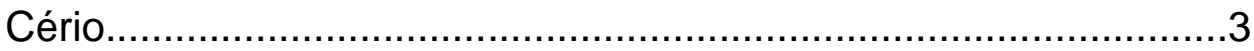

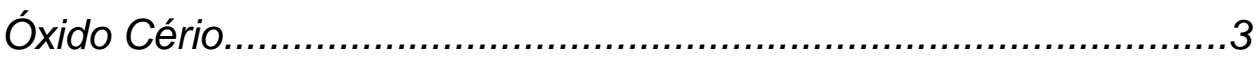

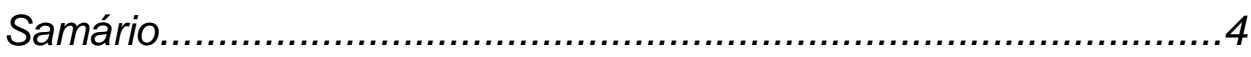

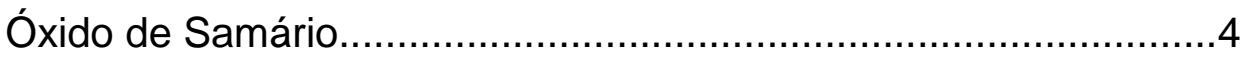

2.2 Solução Sólida - Ceria-Samária....................................................

2.3 Sinterização

Sinterização por reação no estado sólido......................................

Outros processos de sinterização-sinterização em duas etapas..15

2.4 Revisão bibliográfica - sinterização em duas etapas.............................17

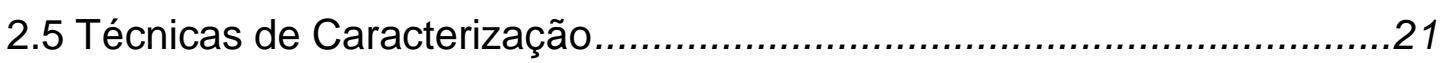

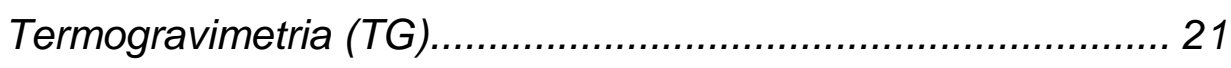

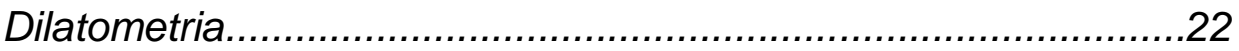

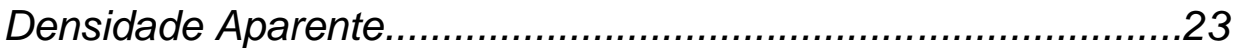

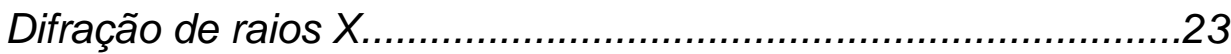

Microscopia Eletrônica de Varredura.........................................24

Determinação do Tamanho Médio de Grãos..............................25

Espectroscopia de Impedância...............................................25

Condutividade Elétrica.............................................................26

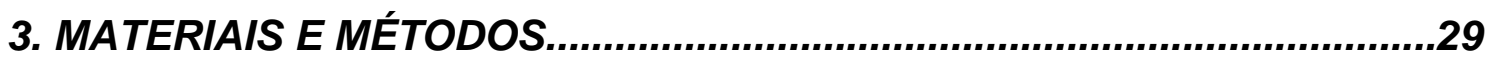

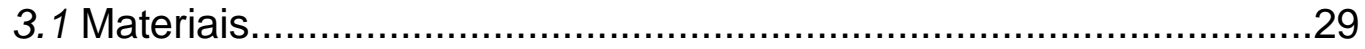

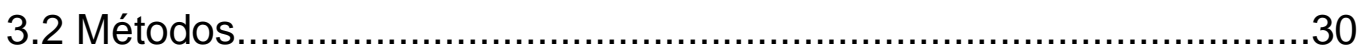

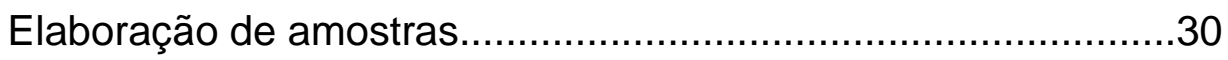

Caracterização das amostras..................................................32

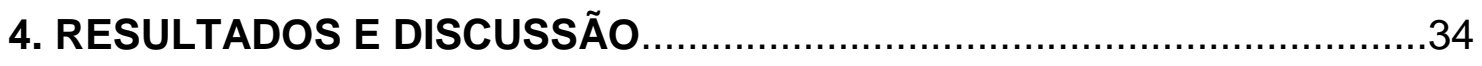

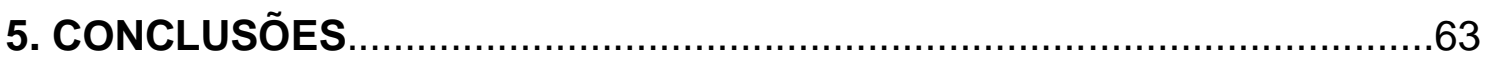

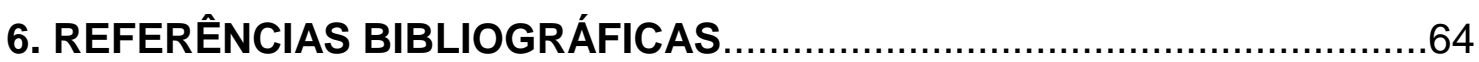




\section{Lista de Figuras}

Figura 1: Estrutura cristalina parcial cúbica tipo fluorita do óxido de cério ( $\square=$ vacância de oxigênio, $O=$ oxigênio, = cério e $\mathbf{O}=$ samário............................

Figura 2: Variação da condutividade iônica em relação ao raio do aditivo, para soluções sólidas de $\left(\mathrm{CeO}_{2}\right)_{0,8}\left(\mathrm{RO}_{1,5}\right)_{0,2}$ a $800^{\circ} \mathrm{C}$...........................................

Figura 3: Trajetórias de transporte de matéria no estágio inicial da

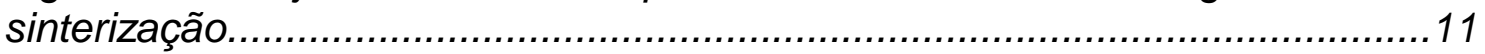

Figura 4: Modelo geométrico de Coble para o estágio intermediário da

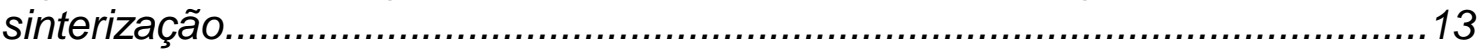

Figura 5: Modelo geométrico de Coble para o estágio final da sinterização.....14

Figura 6: Diagrama de impedância idealizado contendo três

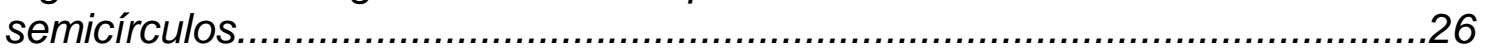

Figura 7: Representação do perfil temperatura-tempo no processo de sinterização em duas etapas 31

Figura 8: Representação do perfil temperatura-tempo no processo de sinterização em duas etapas tradicional.. 31

Figura 9: Micrografias obtidas por microscopia eletrônica de varredura das soluções sólidas a) comercial (SDC1) e b) preparada por mistura de óxidos (SDC2)

Figura 10: Curva termogravimétrica da céria-samária comercial (SDC1).........35

Figura 11: Retração linear da céria-samária (SDC1) durante o aquecimento e resfriamento.

Figura 12: Derivada da curva de retração linear da céria-samária comercial (SDC1).

Figura 13: Curva de densidade relativa em função da temperatura de sinterização obtida a partir da retração linear

Figura 14: Densidade relativa em função da temperatura $T_{1}$ para a solução sólida comercial (SDC1) e a preparada por mistura de óxidos (SDC2). Tempo de patamar $t_{1}=0 \mathrm{~h}$. 38

Figura 15: Densidade relativa em função da temperatura para amostras SDC2 para $T_{1}=1450{ }^{\circ} \mathrm{C}$ com $t_{1}=0 \mathrm{~h}$, e diferentes $T_{2}$ e $t_{2}=5 \mathrm{~h}$. 
Figura 16: Densidade relativa em função do tempo para amostras SDC1 utilizando a sinterização em duas etapas tradicional, onde $T_{1}=1100{ }^{\circ} \mathrm{C}$ por $1 \mathrm{~h}$ e $T_{2}=1450{ }^{\circ} \mathrm{C}$ com diferentes $t_{2}$.......

Figura 17: Difratogramas de raios $X$ das amostras $S D C 1$ e $S D C 2$ em diferentes temperaturas: (a) $1500{ }^{\circ} \mathrm{C} / 0 \mathrm{~h}$ (SDC2-TSS), (b) $1450{ }^{\circ} \mathrm{C} / 0 \mathrm{~h}-1300{ }^{\circ} \mathrm{C} / 5 \mathrm{~h}$ (SDC2-TSS), (c) $1450{ }^{\circ} \mathrm{C} / 0 \mathrm{~h}$ (SDC2-TSS), (d) $1450{ }^{\circ} \mathrm{C} / 0 \mathrm{~h}$ (SDC1-TSS) e

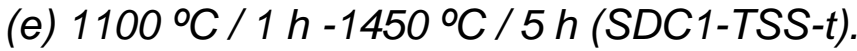
.43

Figura 18: Micrografia obtida em microscópio eletrônico de varredura para amostra SDC1 fraturada e sinterizada em duas etapas (TSS) a $T_{1}=1500^{\circ} \mathrm{C} /$ $0 h$. 44

Figura 19: Micrografia obtida em microscópio eletrônico de varredura para amostra SDC2 fraturada e sinterizada em duas etapas (TSS) a $T_{1}=1500^{\circ} \mathrm{C} / 0$ $h / 1450 \stackrel{\circ}{C} / 5 h$ 44

Figura 20: Micrografias obtidas em microscópio eletrônico de varredura de amostras SDC1 sinterizadas em duas etapas (TSS) na temperatura $T_{1}=1300$ ${ }^{\circ} \mathrm{C} / \mathrm{O} \mathrm{h}$ em diferentes temperaturas $T_{2}$ a) $1250{ }^{\circ} \mathrm{C}$ b) $1275{ }^{\circ} \mathrm{C}$, por tempo $t_{2}=5 h$ 45

Figura 21: Micrografias obtidas em microscópio eletrônico de varredura de amostras SDC1 sinterizadas pelo processo TSS na temperatura $T_{1}=1450 \stackrel{\circ}{\circ}$ / $0 \mathrm{~h}$ em diferentes temperaturas $T_{2}:$ a) $1350 \stackrel{\circ}{\circ}$ e b) $1400 \stackrel{\circ}{\circ}$ e $t_{2}=5 \mathrm{~h}$. 46

Figura 22: Micrografias obtidas em microscópio eletrônico de varredura de amostras SDC1 sinterizadas pelo processo em duas etapas tradicional (TSS-t) na temperatura $T_{1}=1100{ }^{\circ} \mathrm{C} / 1 \mathrm{~h}$ e $T_{2}=1450{ }^{\circ} \mathrm{C}$ em diferentes tempos $t_{2}$ : a) $\left.1 h, b\right) 2 h, e$ c) $5 h$

Figura 23: Micrografia obtida em microscópio eletrônico de varredura de amostra SDC2 sinterizada em duas etapas na temperatura $T_{1}=1450{ }^{\circ} \mathrm{C} / 0 \mathrm{~h}$ e

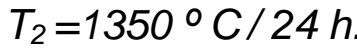
48

Figura 24: Histograma da distribuição de tamanho de grãos para amostras (SDC1) sinterizadas em duas etapas (TSS) com $T_{1}=1300^{\circ} \mathrm{C} / 0 \mathrm{~h}$ e $T_{2}=1275$ ${ }^{\circ} \mathrm{C} / 5 \mathrm{~h}$. 49

Figura 25: Histograma da distribuição de tamanho de grãos para amostras (SDC1) sinterizadas em duas etapas (TSS) com $T_{1}=1450{ }^{\circ} \mathrm{C} / 0 \mathrm{~h}$ e $T_{2}=1300$ ${ }^{\circ} \mathrm{C} / 5 \mathrm{~h}$ 49

Figura 26: Histograma da distribuição de tamanho de grãos para amostras (SDC1) sinterizadas em duas etapas (TSS-t) com $T_{1}=1100 \stackrel{\circ}{\circ} / 1 \mathrm{~h}$ e $T_{2}=1450$ ${ }^{\circ} \mathrm{C} / 1 \mathrm{~h}$. .50

Figura 27: Variação do tamanho médio de grãos para amostras sinterizadas em duas etapas (TSS) $1300{ }^{\circ} \mathrm{C} / \mathrm{O} \mathrm{h} / 1250^{\circ} \mathrm{C}$ e sinterização em duas etapas tradicional (TSS-t) $1100 \stackrel{\circ}{\circ} / 1 \mathrm{~h} / 1450{ }^{\circ} \mathrm{C}$ em função de $t_{2}$. .52 
Figura 28: Variação do tamanho médio de grãos para as amostras sinterizadas em duas etapas (TSS) $1300 \stackrel{\circ}{\circ} / 0 \mathrm{~h} / 1250{ }^{\circ} \mathrm{C} / \mathrm{t}_{2}$ e sinterizadas em duas etapas tradicional (TSS-t) $1100{ }^{\circ} \mathrm{C} / 1 \mathrm{~h} / 1450{ }^{\circ} \mathrm{C} / \mathrm{t}_{2}$ em função da densidade relativa..52

Figura 29: Diagrama de impedância da amostra sinterizada em duas etapas na temperatura $T_{1}=1330{ }^{\circ} \mathrm{C} / 0 \mathrm{~h}$ e $T_{2}=1200{ }^{\circ} \mathrm{C} / 5 \mathrm{~h}$. Temperatura de medida $245^{\circ} \mathrm{C}$ .53

Figura 30: Diagrama de impedância da amostra sinterizada em duas etapas na temperatura $T_{1}=1450{ }^{\circ} \mathrm{C} / 0 \mathrm{~h}$ e $T_{2}=1425{ }^{\circ} \mathrm{C} / 5 \mathrm{~h}$. Temperatura de medida $252,5 \stackrel{\circ}{\circ} \mathrm{C}$. .54

Figura 31: Diagrama de impedância da amostra sinterizada em duas etapas tradicional na temperatura $T_{1}=1100{ }^{\circ} \mathrm{C} / 1 \mathrm{~h}$ e $T_{2}=1450{ }^{\circ} \mathrm{C} / 5 \mathrm{~h}$. Temperatura de medida $249 \stackrel{\circ}{\circ} \mathrm{C}$ 54

Figura 32: Gráficos de Arrhenius da condutividade elétrica dos grãos das amostras sinterizadas em duas etapas (TSS) para $T_{1}=1300{ }^{\circ} \mathrm{C} / 0 \mathrm{~h}$ em diferentes temperaturas $T_{2}$ e $t_{2}=5$ e $10 \mathrm{~h}$. 55

Figura 33: Gráficos de Arrhenius da condutividade elétrica dos grãos das amostras sinterizadas em duas etapas (TSS) para $T_{1}=1450{ }^{\circ} \mathrm{C} / 0 \mathrm{~h}$ em diferentes temperaturas $T_{2}$ e $t_{2}=5 \mathrm{~h}$.

Figura 34: Gráficos de Arrhenius da condutividade elétrica dos contornos de grão das amostras sinterizadas em duas etapas (TSS) para $T_{1}=1300 \stackrel{\circ}{\circ} / 0 \mathrm{~h}$ em diferentes temperaturas $T_{2}$ e $t_{2}=5 \mathrm{~h}$ e $10 \mathrm{~h}$

Figura 35: Gráficos de Arrhenius da condutividade elétrica dos contornos de grão das amostras sinterizadas em duas etapas (TSS) para $T_{1}=1450{ }^{\circ} \mathrm{C} / 0 \mathrm{~h}$ em diferentes temperaturas $T_{2}$ 58

Figura 36: Gráficos de Arrhenius da condutividade elétrica dos grãos das amostras sinterizadas em duas etapas tradicional (TSS-t) para diferentes $T_{1} e$ $t_{1}=1 \mathrm{~h}$ e $T_{2}=1450^{\circ} \mathrm{C} / 5 \mathrm{~h}$.

Figura 37: Gráficos de Arrhenius da condutividade elétrica dos contornos de grão das amostras sinterizadas em duas etapas tradicional (TSS-t) para diferentes $T_{1}$ e $t_{1}=1 \mathrm{~h}$ e $T_{2}=1450^{\circ} \mathrm{C} / 5 \mathrm{~h}$.

Figura 38: Gráficos de Arrhenius da condutividade elétrica dos grãos das amostras: $1450 \stackrel{\circ}{\circ} / 0 h / 1425{ }^{\circ} \mathrm{C} / 5 \mathrm{~h}$ (TSS), $1300^{\circ} \mathrm{C} / 0 \mathrm{~h} / 1275{ }^{\circ} \mathrm{C} / 5 \mathrm{~h}$ (TSS), $1200{ }^{\circ} \mathrm{C} / 0 \mathrm{~h} / 1450{ }^{\circ} \mathrm{C} / 5 \mathrm{~h}$ (TSS-t) e $1100{ }^{\circ} \mathrm{C} / 0 \mathrm{~h} / 1450{ }^{\circ} \mathrm{C} / 5 \mathrm{~h}$ 60

Figura 39: Gráficos de Arrhenius da condutividade elétrica dos contornos de grão das amostras: $1450{ }^{\circ} \mathrm{C} / 0 \mathrm{~h} / 1425{ }^{\circ} \mathrm{C} / 5 \mathrm{~h}$ (TSS), $1300{ }^{\circ} \mathrm{C} / 0 \mathrm{~h} / 1275^{\circ} \mathrm{C} / 5$ $h$ (TSS), $1200{ }^{\circ} \mathrm{C} / 0 \mathrm{~h} / 1450{ }^{\circ} \mathrm{C} / 5 \mathrm{~h}$ (TSS-t) e $1100{ }^{\circ} \mathrm{C} / 0 \mathrm{~h} / 1450{ }^{\circ} \mathrm{C} / 5 \mathrm{~h} . . .61$ 


\section{Lista de Tabelas}

Tabela I - Características do elemento Ce.....................................................

Tabela II - Características do elemento Sm...................................................4

Tabela III - Características físicas e químicas do óxido de cério e óxido de

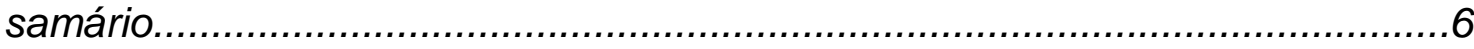

Tabela IV - Mecanismos de transporte de matéria durante o estágio inicial de sinterização.................................................................................... 11

Tabela V - Características físicas e químicas dos materiais de partida...........29

Tabela VI - Lista de códigos utilizados.................................................. 30

Tabela VII - Densidade relativa de amostras SDC1 sinterizadas em duas

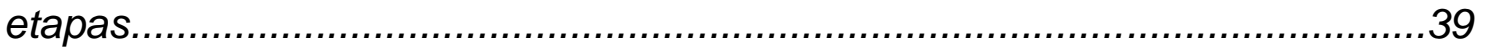

Tabela VIII - Condições de sinterização e densidade relativa para amostras obtidas por mistura de óxidos (SDC2) .................................................42

Tabela IX - Tamanho médio de grão para as amostras (SDC1) sinterizadas em duas etapas com $T_{1}=1300^{\circ} \mathrm{C}$ e $T_{1}=1450^{\circ} \mathrm{C}$ em diferentes temperaturas $T_{2} \mathrm{e}$ $t_{2}$ e amostras sinterizadas em duas etapas tradicional com $T_{1}=1100^{\circ} \mathrm{C} / 1 \mathrm{~h}$ e $T_{2}=1450{ }^{\circ} \mathrm{C}$ em diferentes tempos $t_{2} . D V=$ dispersão no valor de tamanho édio. 51

Tabela $X$ - Valores de energia de ativação do processo de condução dos grãos $E_{g}$, contornos de grão, $E_{c g}$ e total, $E_{T}$, para amostras $T S S \operatorname{com} T_{1}=1300^{\circ} \mathrm{C} e$ $T_{1}=1450{ }^{\circ} \mathrm{C} / 0 \mathrm{~h}$ e diferentes temperaturas $T_{2}$ e para amostras TSS-t com diferentes temperaturas $T_{1}$ por $1 \mathrm{~h}$ e $\mathrm{T}_{2}=1450^{\circ} \mathrm{C} / 5 \mathrm{~h}$ 


\section{INTRODUÇÃO}

O óxido de cério (ou céria), puro ou contendo aditivos, é um material que tem atraído a atenção de muitos pesquisadores por apresentar amplo potencial de utilização em catálise, como material para polimento, em sensores, e em células a combustível de óxido sólido (SOFC), como eletrólito sólido e/ou eletrodo na conversão de energia química em energia elétrica [1].

Para muitas das aplicações citadas o óxido de cério encontrado comercialmente pode ser utilizado com sucesso. Existem algumas aplicações, contudo, que requerem propriedades tais que o material comercial não consegue atingir. Assim, muitos trabalhos podem ser encontrados na literatura relacionados com a síntese ou com o processamento da céria que visam melhorar uma ou mais de suas propriedades. O seu potencial de utilização em células a combustível de óxido sólido, por exemplo, tem sido muito discutido. Isto porque a céria apresenta alguns problemas ainda não resolvidos para este tipo de aplicação. Os mais importantes são: a facilidade de redução do $\mathrm{Ce}^{4+}$ para $\mathrm{Ce}^{3+}$ em atmosferas redutoras e altas temperaturas, e a dificuldade em obter cerâmicas densas mesmo com tratamentos térmicos em altas temperaturas (>1400 ${ }^{\circ} \mathrm{C}$ ) e empregando pós sintetizados quimicamente [2]. Para melhorar a sinterabilidade da céria, existem algumas abordagens tais como otimizações na síntese de pós ultrafinos, o emprego de aditivos de sinterização e a utilização de métodos de sinterização diferentes do convencional.

Considerando que a céria-samária é um material de interesse tecnológico, que um dos problemas ainda não solucionados com relação a este material é sua baixa sinterabilidade, e os poucos trabalhos científicos onde esta propriedade foi estudada, os principais objetivos deste trabalho são:

- Estudo da densificação da céria-samária com o uso da técnica de sinterização em duas etapas,

- Identificação de algumas variáveis no sucesso deste processo, tais como: material de partida e temperaturas utilizadas nas duas etapas, 
- Avaliação do tamanho de grãos nas cerâmicas sinterizadas por microscopia eletrônica.

- Análise da eficiência do método na obtenção de cerâmicas densas e com tamanho de grãos reduzidos na céria-samária frente ao método convencional de sinterização, tendo em conta a sua condutividade iônica. 


\section{FUNDAMENTOS TEÓRICOS}

Neste capítulo serão apresentadas algumas características dos materiais utilizados e serão abordados brevemente alguns temas de interesse para o trabalho.

\subsection{Características Gerais}

Cério

O cério foi descoberto na Suécia por Jöns Jacob Berzelius e Wilhelm Von Hisinger, e independentemente na Alemanha por Martin Heinrich Klaproth, ambos em 1803.

O cério foi assim nomeado por Berzelius em homenagem ao asteróide Ceres descoberto dois anos antes (1801). O metal foi isolado em 1875 por Norton e Hillebrand [3]. Algumas características do elemento são listadas na tabela I.

Tabela I - Características do elemento Ce [3].

\begin{tabular}{cc}
\hline Características & Cério \\
\hline Numero atômico & 58 \\
Energia de ionização & $5,5387 \mathrm{eV}$ \\
Raio atômico & $181,8 \mathrm{pm}$ \\
Valência & $3+, 4+$ \\
Massa atômica & 140,115 \\
\hline
\end{tabular}

Óxido Cério

O óxido de cério tem estrutura cristalina típica da fluorita sendo estável à temperatura ambiente. Na estrutura cristalina do óxido de cério, o cério tem número de coordenação 8 , ou seja, cada íon cério tem oito oxigênios com vizinhos mais próximos, enquanto que o oxigênio tem número de coordenação 4, ou seja, cada íon oxigênio tem quatro íons cério como vizinhos mais próximos. 
$\mathrm{O} \mathrm{CeO}_{2}$ é um semicondutor tipo $n$, mas a introdução de aditivos de menor valência favorece a condução dos íons oxigênio. Os aditivos mais utilizados são os óxidos de terras raras trivalentes, que apresentam alta solubilidade na céria.

Samário

Foi descoberto em 1879 por Lecoq de Boisbaudran, pela análise espectral da samarskite (mineral de urânio e tório, contendo samário como impureza).

A origem do seu nome e do mineral samarskite, no qual foi descoberto, foi dado em homenagem ao coronel russo Samarski.

O samário é encontrado juntamente com os demais membros dos elementos de terras raras em vários minerais, incluindo monazita e bastnasita [3]. Algumas características do elemento são mostradas na tabela II.

Tabela II - características do elemento Sm [3].

\begin{tabular}{cc}
\hline Características & samário \\
\hline Numero atômico & 62 \\
Energia de ionização & $5,6437 \mathrm{eV}$ \\
Raio atômico & $180 \mathrm{pm}$ \\
Valência & $2+, 3+$ \\
Massa atômica & 150,36 \\
\hline
\end{tabular}

Óxido de Samário

O óxido de samário possui uma estrutura cúbica tipo-C, característica das terras raras, até 850-900 ${ }^{\circ} \mathrm{C}$, quando se transforma em estrutura tipo-B que é estável até $1820^{\circ} \mathrm{C}$. Acima dessa temperatura transforma-se em estruturas do tipo A, $\mathrm{H}$ e X. O $\mathrm{Sm}_{2} \mathrm{O}_{3}$ é um condutor essencialmente iônico [4]. 


\subsection{Solução Sólida - Ceria-Samária}

Solução Sólida é uma fase cristalina que pode ter combinação variável, podendo ser do tipo substitucional ou intersticial [5].

Quando o óxido de cério é tratado termicamente a alta temperatura com óxidos de terras raras $\left(\mathrm{Y}_{2} \mathrm{O}_{3}, \mathrm{Sm}_{2} \mathrm{O}_{3}, \mathrm{Gd}_{2} \mathrm{O}_{3}, \mathrm{Dy}_{2} \mathrm{O}_{3}\right)$ pode acontecer a substituição parcial de alguns íons $\mathrm{Ce}$ por íons de terras raras na estrutura cristalina dando origem a uma solução sólida do tipo substitucional, onde o cátion do aditivo assume a posição do cátion hospedeiro. Devido à diferença de valência entre os cátions hospedeiro $\left(\mathrm{Ce}^{4+}\right)$ e aditivo $\left(\mathrm{Sm}^{3+}\right)$, são formados defeitos complementares, para que a condição de neutralidade elétrica seja mantida. A introdução do óxido de samário na estrutura cristalina do óxido de cério ocorre de acordo com a equação (1).

$$
\mathrm{Sm}_{2} \mathrm{O}_{3}+2 \mathrm{Ce}_{\mathrm{Ce}}^{X}+4 \mathrm{O}_{O}^{X} \longrightarrow 2 \mathrm{Sm}_{\mathrm{Ce}}+\mathrm{V}_{\mathrm{O}}+3 \mathrm{O}_{\mathrm{O}}^{X}+2 \mathrm{CeO}_{2}
$$

na qual, de acordo com a notação de Kröger e Vink [6], $C e_{C e}^{X}$ e $O_{o}^{X}$ representam as espécies em seus sítios regulares na rede, $S m_{C e}$ corresponde ao $\mathrm{Sm}^{3+}$ em substituição ao $\mathrm{Ce}^{4+}$, com formação de uma carga negativa, e $V_{o}$ é a vacância de oxigênio formada (positivamente carregada), como defeito complementar. Para cada dois íons $\mathrm{Ce}^{4+}$ substituídos, uma vacância de oxigênio é formada. Uma representação esquemática típica da estrutura fluorita com substituição parcial é mostrada na figura 1. 


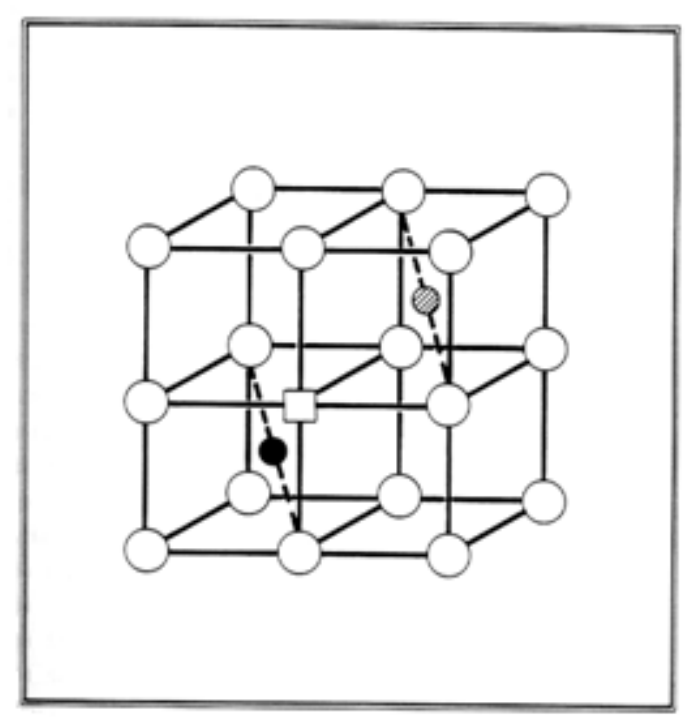

Figura 1: Estrutura cristalina parcial cúbica tipo fluorita do óxido de cério ( $=\square$ vacância de oxigênio , $\mathrm{O}$ = oxigênio, = cério e $\mathbf{O}$ = samário.)

Soluções sólidas de céria contendo terras raras, principalmente gadolínio e samário, têm sido muito estudadas nos últimos anos para aplicação em células a combustível de óxido sólido, tanto como eletrólito sólido como componente de eletrodos. Essas soluções sólidas apresentam alta condutividade iônica a temperaturas intermediárias (500 a $750 \stackrel{\circ}{\circ}$ ) possibilitando reduzir a temperatura de operação, e resultando em redução de custo deste dispositivo [7].

A tabela III mostra algumas características físicas e químicas do óxido de cério e do óxido de samário.

Tabela III - características físicas e químicas do óxido de cério e óxido de samário [3].

\begin{tabular}{lcc}
\hline Características & $\mathrm{CeO}_{2}$ & $\mathrm{Sm}_{2} \mathrm{O}_{3}$ \\
\hline Massa molecular & 172,115 & 348,72 \\
Temperatura de fusão & $2480{ }^{\circ} \mathrm{C}$ & $2269{ }^{\circ} \mathrm{C}$ \\
Temperatura de ebulição & $3443{ }^{\circ} \mathrm{C}$ & $3780{ }^{\circ} \mathrm{C}$ \\
Densidade & $7,216 \mathrm{~g} / \mathrm{cm}^{3}$ & $7,09 \mathrm{~g} / \mathrm{cm}^{3}$ \\
Estrutura cristalina & Cúbica tipo fluorita & Cúbica tipo C \\
Parâmetro de rede & $5,4110 \AA$ & $10,93 \AA$ \\
\hline
\end{tabular}


A figura 2 mostra os valores de condutividade elétrica para o óxido de cério contendo terras raras trivalentes $\left(\mathrm{R}_{2} \mathrm{O}_{3}\right)$, em função do raio iônico do aditivo [8]. Pelo gráfico observa-se um aumento da condutividade com o aumento do raio iônico, atingindo um valor ótimo para o cátion $\mathrm{Sm}^{3+}$, mas para valores de $r>1,09 \mathrm{~nm}$ o valor da condutividade diminui [9].

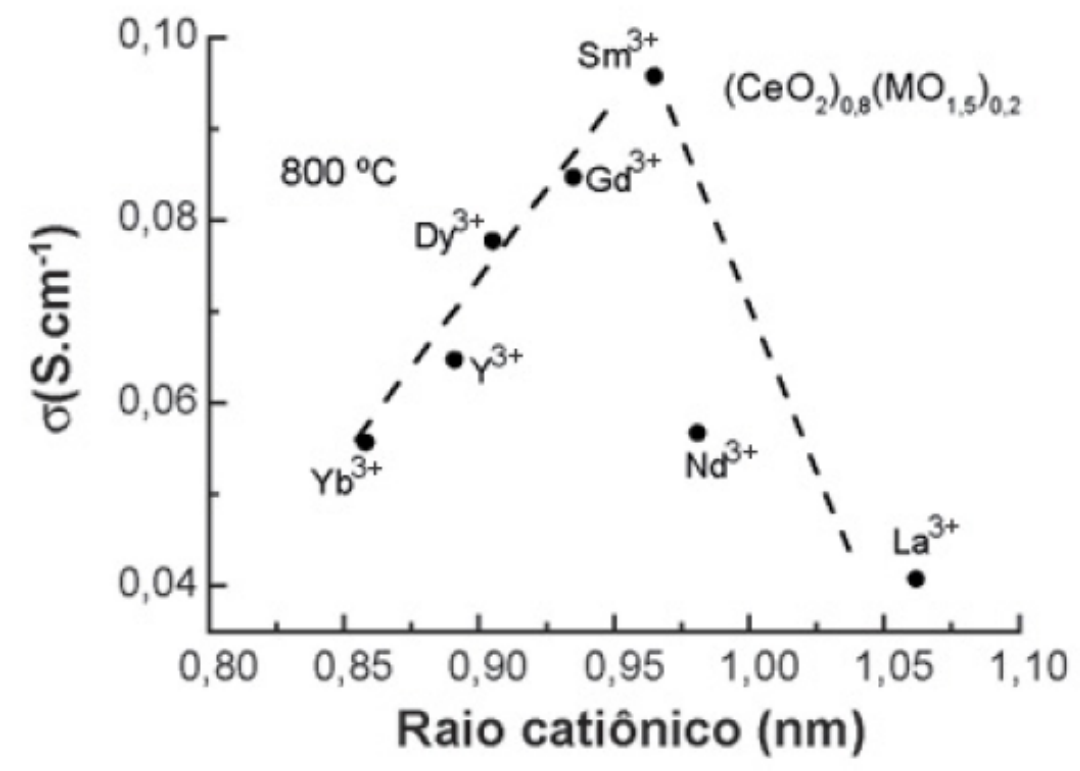

Figura 2: Variação da condutividade iônica em relação ao raio do aditivo, para soluções sólidas de $\left(\mathrm{CeO}_{2}\right)_{0,8}\left(\mathrm{RO}_{1,5}\right)_{0,2}$ a $800{ }^{\circ} \mathrm{C}[8]$.

Dessa forma, estes resultados experimentais evidenciaram que, dentre os óxidos de cério contendo terras raras como aditivos, a solução sólida $\mathrm{Ce}_{0,8} \mathrm{Sm}_{0,2} \mathrm{O}_{1,9}$ apresenta o maior valor de condutividade iônica. Este resultado foi confirmado posteriormente $[9,10]$.

Os valores da condutividade iônica nas soluções sólidas à base de céria são elevados o suficiente para que estas sejam também denominadas eletrólitos sólidos, em analogia aos eletrólitos líquidos.

Eletrólitos sólidos são materiais cristalinos ou amorfos com estrutura que permitem o transporte de íons, devido à formação de defeitos puntiformes (vacâncias ou intersticiais), que têm origem, principalmente através da formação da solução sólida [11, 12]. 


\subsection{Sinterização}

A sinterização pode ser definida como um processo físico, termicamente ativado, no qual, pós cristalinos ou não, compactados, são tratados termicamente, em uma temperatura abaixo de sua temperatura de fusão, envolvendo uma mudança na microestrutura desse material $[13,14]$.

O processo envolve transporte de matéria, podendo ocorrer tanto por reação no estado sólido quanto com a presença de fase líquida. Estes dois tipos básicos de sinterização são capazes de densificar total ou parcialmente o material em estudo, sendo que com o primeiro tipo é possível obter uma estrutura com porosidade controlada, enquanto que o fechamento total da porosidade é mais facilmente obtido através da sinterização por fase líquida [15].

O processo de sinterização é influenciado por vários parâmetros como: temperatura e tempo de sinterização; tamanho e distribuição de tamanho de partículas e poros na amostra; homogeneidade da mistura; composição do material, incluindo aditivos; atmosfera de sinterização e pressão de compactação, dentre outros [16].

A força motriz para a sinterização é a redução da energia livre do sistema, que é possível pela diminuição das áreas de superfície especifica e interfaces da amostra. Pode ocorrer a densificação e o crescimento de grãos. A densificação se dá com a mudança das interfaces sólido-gás e partícula-poro, para a interface sólido-sólido de menor energia. O crescimento de grãos acontece com a transformação de muitos grãos pequenos, originários das partículas do compacto, para um número menor de grãos maiores [13].

O material estudado neste trabalho, na ausência de aditivos específicos que promovam a formação de fase líquida, sinteriza por reações em estado sólido, por isso esse tópico será detalhado a seguir. 


\section{Sinterização por reação no estado sólido}

Neste caso, o material é transportado sem que haja qualquer tipo de líquido na estrutura, ou se existir, sua quantidade é insignificante de tal forma que não irá influenciar na sinterização do compacto.

As reações que ocorrem na sinterização por reação em estado sólido são termicamente ativadas e algumas dessas reações ocorrem espontaneamente quando uma temperatura particular é atingida; outras reações ocorrem lentamente em um amplo intervalo de tempo e somente entre as partículas em contato. Nesse caso, não só a temperatura, mas também o tamanho de partícula e a área de contato entre elas são muito importantes.

Em geral as reações envolvem três processos subsequentes: o transporte de substâncias potencialmente reativas (íons) para as superfícies de contato dos componentes em reação, a própria reação entre os componentes em contato e o transporte dos produtos das reações para fora dos lugares onde ocorre a reação, ou seja, as reações dependem da taxa de transporte dos reagentes e produtos das reações. Por esse motivo, em geral, a difusão é o único processo que determina as reações e suas taxas [13].

Assumindo que durante as reações químicas no estado sólido os íons se difundem pelo cristal, seu movimento está conectado com o movimento das vacâncias, que são substituídas pelos íons móveis. Os saltos dos íons, de uma posição da rede para a próxima é dependente de certa quantidade de energia que é requerida para que a barreira de energia seja superada, a energia de ativação. Quando a temperatura aumenta, o número de vacâncias que pode vencer a barreira aumenta exponencialmente facilitando as reações no estado sólido. A temperatura é sem dúvida o principal parâmetro que controla o curso dessas reações, mas a altura da barreira de energia, ou seja, a magnitude da energia de ativação é também influenciada pela pureza, estequiometria e estrutura do material, valência dos íons que se difundem e suas dimensões, dentre outros [17].

A sinterização por reação em estado sólido ocorre em três estágios muitas vezes não distinguíveis entre si. 
No estágio inicial de sinterização ocorre 0 arredondamento das partículas, a formação de pescoço, ou seja, há um aumento na área de contato entre as partículas. Durante esse estágio as partículas iniciais de pó ainda são distinguíveis. Há pouco ou nenhum crescimento de grão, pouca redução na área de superfície específica e na porosidade. Se houver densificação esta será até $\sim 3 \%$.

No estágio intermediário, a inibição à movimentação do contorno de grão desaparece, depois de um crescimento considerável do pescoço, sendo possível o crescimento de grão. Durante esse estágio as partículas individuais perdem suas identidades, há eliminação da maior parte dos poros acompanhado de densificação, devido à ação das respectivas energias e tensões superficiais. Ainda neste estágio ocorre a maior parte da densificação. Os poros permanecem, em sua maioria, interconectados.

O estágio final de sinterização é caracterizado pelo crescimento dos grãos. Ainda neste estágio pode ocorrer a remoção completa dos poros remanescentes, conduzindo à densificação completa do material. Porém pode ocorrer o crescimento descontínuo dos grãos maiores às custas dos menores [4].

No primeiro estágio do processo de sinterização por reações em estado sólido são identificados seis mecanismos de transporte de matéria, que indicam os caminhos do fluxo de massa devido à força motriz [18]. Na tabela IV são listados esses mecanismos e na Figura 3 são mostrados os caminhos de transporte da matéria. 
Tabela IV - Mecanismos de transporte de matéria durante o estágio inicial de sinterização [18].

\begin{tabular}{cccc}
\hline Mecanismos & Meios de transporte & Fonte & Absorvedor \\
\hline 1 & Difusão superficial & Superfície & Pescoço \\
2 & Difusão em volume & Superfície & Pescoço \\
3 & Transporte de vapor & Superfície & Pescoço \\
4 & Difusão via contornos & Contorno de & Pescoço \\
& de grão & grão & \\
5 & Difusão em volume & Contorno de & Pescoço \\
& & grão & \\
6 & Difusão em volume & Discordâncias & Pescoço \\
\hline
\end{tabular}

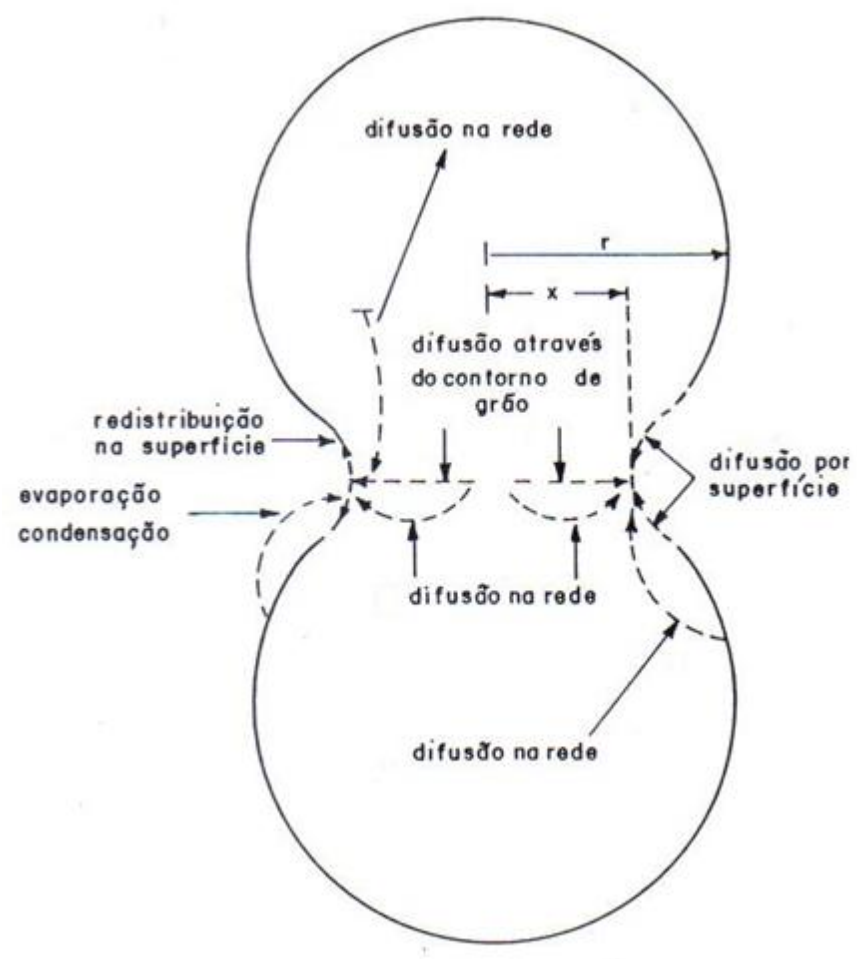

Figura 3: Trajetórias de transporte de matéria no estágio inicial da sinterização.

Estes mecanismos contribuem para a formação do pescoço e podem contribuir para a densificação do material. Todos os mecanismos podem contribuir simultaneamente para o crescimento do pescoço. Porém somente os mecanismos 4, 5 e 6 conduzem à densificação, já que o material não é proveniente da superfície. 
Os mecanismos de transporte de matéria determinam a ação do fluxo de massa durante a sinterização. Eles podem ser classificados em superficiais ou volumétricos.

O transporte superficial pode ocorrer por mecanismos de evaporaçãocondensação e difusão superficial e o transporte volumétrico de matéria pode ser realizado por difusão volumétrica, difusão por contornos de grão, escoamento plástico e escoamento viscoso.

O mecanismo, evaporação-condensação, é caracterizado por um aumento da pressão de vapor com o aumento da temperatura, e o fluxo de transporte de massa maior via fase vapor. A evaporação ocorre preferencialmente a partir de superfícies planas ou convexas das partículas, enquanto que a deposição ocorre nos pescoços, regiões de formato côncavo. Este costuma ser um processo dominante principalmente para pós finos, com alta área de superfície específica e alta pressão de vapor [14].

O transporte de matéria por difusão superficial ocorre pelo movimento ao longo das superfícies das partículas, que são rugosas e incluem defeitos, tais como bordas e vacâncias. Os átomos se movimentam entre essas regiões de defeitos. É um processo termicamente ativado [14].

A difusão volumétrica envolve o movimento de vacâncias através da estrutura cristalina, sendo que a taxa de difusão é função da temperatura, composição e curvatura das partículas [14].

No mecanismo de difusão via contornos de grão, a matéria é removida ao longo dos contornos, e depositada na intersecção dos contornos com a superfície do pescoço [14].

O transporte de matéria por escoamento plástico ocorre pelo movimento via estrutura de discordâncias sob tensão. Durante o aquecimento, há geração de discordâncias no material, que interagem com as vacâncias durante a sinterização [14]. Este mecanismo é restrito a materiais metálicos.

O fluxo viscoso ocorre em materiais amorfos como vidros e polímeros que exibem uma diminuição da viscosidade com o aumento da temperatura. Sob a ação de uma tensão aplicada, o material escoará. Então, para altas temperaturas, pós de vidros e polímeros densificam em resposta à tensão de sinterização [14]. 
O estágio intermediário é o mais importante para a densificação e determinação das propriedades do compacto sinterizado. Ele é caracterizado pela simultânea densificação, arredondamento dos poros e pouco crescimento de grãos. Os poros durante esse estágio apresentam forma alongada e são interligados, figura $4[14,19]$.

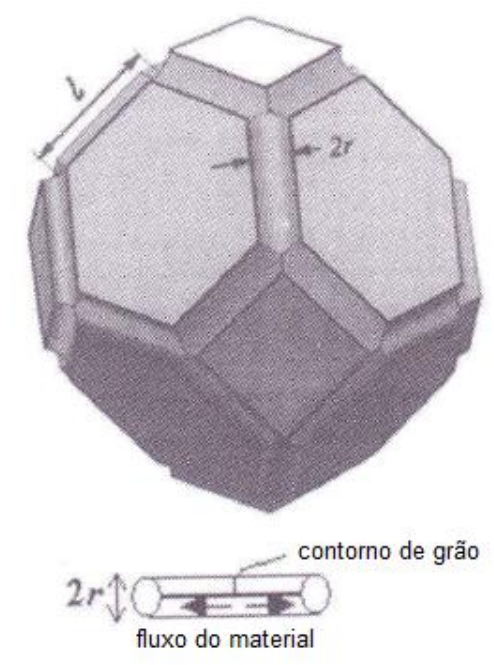

Figura 4: Modelo geométrico de Coble para o estágio intermediário da sinterização [19].

Coble [20] propôs um modelo de difusão durante os estágios intermediário e final da sinterização. Os mecanismos predominantes nesses estágios são a difusão via rede (ou volumétrica) e a difusão via contornos de grão.

Na difusão volumétrica a taxa de densificação é dada por:

$$
\frac{d \rho}{d t} \propto \frac{D_{l} \gamma_{s} V_{m}}{R T G^{3}}
$$

onde:

$\rho$ é a densidade relativa

t é o tempo

$\mathrm{D}_{l}$ é o coeficiente de difusão via rede

$\gamma_{\mathrm{s}}$ é a energia de superfície específica do sólido

$\mathrm{V}_{m}$ volume molar do sólido

$R$ constante ideal dos gases

G é o tamanho de grão

$T$ é a temperatura 
A equação (2) indica que a difusão volumétrica é inversamente proporcional ao tamanho de grão elevado ao cubo.

Para a difusão via contornos de grão, a taxa de densificação é dada por:

$$
\frac{d \rho}{d t} \propto \frac{D_{b} \delta_{b} \gamma_{s} V_{m}}{R T G^{4}}\left(\frac{1}{P_{v}}\right)^{\frac{1}{2}}
$$

onde:

$\mathrm{D}_{b}$ é o coeficiente de difusão via contornos de grão

$\delta_{b}$ é a espessura dos contornos de grão, e

$\mathrm{P}_{v}$ é a porosidade

A difusão via contorno de grão é inversamente proporcional ao tamanho de grão elevado à quarta potência.

O estágio final de sinterização é caracterizado pelo crescimento de grãos e pode ocorrer a eliminação da porosidade residual. Os poros neste estágio apresentam forma aproximadamente esférica e não são mais interligados, figura $5[14,19]$.

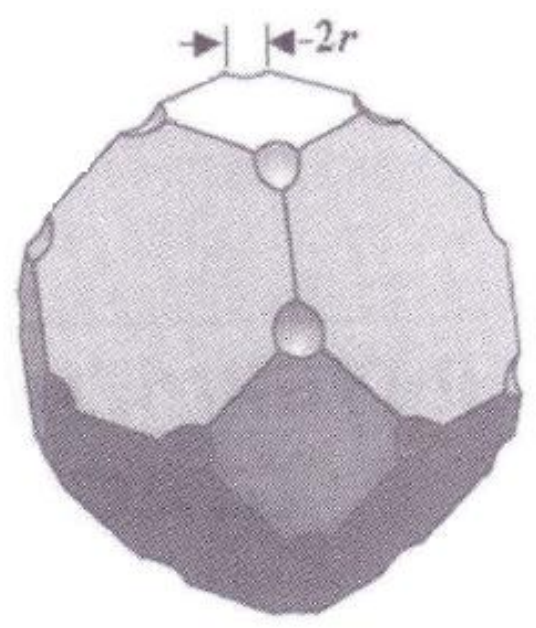

Figura 5: Modelo geométrico de Coble para o estágio final da sinterização [19].

Nesse estágio a taxa de densificação para a difusão volumétrica é dada pela equação (4): 


$$
\frac{d \rho}{d t} \propto \frac{D_{l} \gamma_{s} V_{m}}{R T G^{3}}(1-\rho)^{\frac{1}{3}}
$$

Para a difusão via contorno de grão, a taxa de densificação é dada por:

$$
\frac{d \rho}{d t} \propto \frac{D_{b} \delta_{b} \gamma_{s} V_{m}}{R T G^{4}}
$$

Verifica-se que também neste estágio final de sinterização a taxa de densificação aumenta com o tamanho médio de grão elevado à terceira e quarta potência para os mecanismos de difusão volumétrica e via contornos de grão, respectivamente.

Durante o estágio intermediário de sinterização, o crescimento de grãos começa a se tornar um fator importante e predomina no estágio final. $\mathrm{Na}$ ausência de crescimento anisotrópico de grãos, um material policristalino tem o crescimento de grãos $G$ dado em função do tempo $t$ de acordo com a equação (6).

$$
G^{m}=G_{o}^{m}+K t
$$

Onde $G_{0}$ é o tamanho médio de grão inicial, $K$ é igual a um produto de constantes multiplicadas à mobilidade dos contornos de grãos e usualmente $m$ é igual a 2 ou 3. De acordo com a teoria originalmente proposta tem-se que $m$ $=2$, ou seja, o tamanho médio de grãos aumenta com a raiz quadrada do tempo de sinterização. Entretanto, devido a uma série de fatores, frequentemente se observa que $m=3$, enquanto que para materiais policristalinos na forma de filmes $m=\frac{1}{2}$ [19].

Outros Processos de Sinterização - Sinterização em Duas Etapas

Por outros processos de sinterização entendem-se aqueles onde é aplicada simultaneamente pressão, como a prensagem a quente e isostática a quente; ou onde a sinterização ocorre por meio de uma reação química, como a sinterização reativa, ou ainda onde o tratamento térmico é realizado de forma 
diferente do tradicional. Nesta última categoria estão a sinterização por feixe de plasma, por microondas, por feixe de elétrons, etc.

Recentemente foi proposta na literatura uma nova abordagem para a sinterização de materiais cerâmicos policristalinos, na qual o aquecimento é realizado em forno convencional, mas o processo é dividido em duas etapas.

A sinterização em duas etapas (TSS - "Two Step Sintering"), proposta em 2000 por Chen e Wang [21], tem como premissa a obtenção de cerâmicas densas e com tamanho de grãos reduzidos, porque suprime o crescimento de grãos que ocorre no estágio final de sinterização. Portanto, este método se baseia na densificação sem crescimento de grão no estágio final de sinterização. Assim, a amostra é inicialmente conduzida a uma alta temperatura por tempo quase nulo, sendo em seguida resfriada rapidamente até uma temperatura inferior na qual permanece por um tempo específico. Segundo os autores, a eficácia da densificação neste caso se deve à supressão da migração dos contornos de grão ao mesmo tempo em que é mantida a difusão via contornos de grão. Para que o processo seja otimizado os autores mostraram que uma densidade relativa em torno de $75 \%$ deve ser obtida na primeira etapa de sinterização, quando esta se processa por reação em estado sólido.

Neste trabalho, para efeito de comparação, foi também utilizada a técnica de sinterização em duas etapas "tradicional" em que a amostra é conduzida a uma determinada temperatura por um tempo de patamar curto e em seguida aquecida a uma temperatura superior por um tempo de patamar longo. Neste caso, o objetivo consiste em obter maior homogeneidade na estrutura de poros com o primeiro patamar de sinterização e, com isto, aumentar a densificação no segundo patamar, sem se preocupar com o crescimento de grãos.

Para alguns materiais cerâmicos a microestrutura a verde é heterogênea. Isto acontece, por exemplo, quando existem aglomerados no material particulado. Foi mostrado que nesses casos, um pré-engrossamento ("pré-coarsening"), ou seja, um tratamento térmico a temperaturas inferiores àquela na qual tem início a densificação, pode resultar numa melhor homogeneidade da microestrutura, produzindo benefícios para a densificação e controle microestrutural [22]. O processo de sinterização, como um todo, 
consistindo de uma etapa de pré-engrossamento seguida pela etapa de densificação é também denominado sinterização em duas etapas. Neste trabalho, será chamado de sinterização em duas etapas tradicional. Este processo foi reportado resultar em melhorias na homogeneidade microestrutural em compactos de $\mathrm{MgO}, \mathrm{ZnO}$ e $\mathrm{Al}_{2} \mathrm{O}_{3}$ [23-25].

No caso específico da alumina foi mostrado que o pré-engrossamento a $800 \stackrel{\circ}{\circ}$ por $50 \mathrm{~h}$ resultou numa microestrutura a verde com porosidade mais uniforme em tamanho e distribuição, quando comparada com a microestrutura original. $\mathrm{Na}$ sinterização subsequente a 1450 ำ houve também homogeneização da microestrutura e os compactos atingiram alta densidade (99\% da densidade teórica), tamanho de grão relativamente pequeno $(\sim 1,2 \mu \mathrm{m})$ e distribuição estreita de tamanho.

\subsection{Revisão bibliográfica - sinterização em duas etapas}

Em 2000, Chen e Wang propuseram um novo método de sinterização denominado sinterização em duas etapas (TSS - "Two Step Sintering"), para $\mathrm{Y}_{2} \mathrm{O}_{3}$ com o objetivo de obter cerâmicas densas e com tamanho de grãos reduzidos [21].

Posteriormente, alguns trabalhos foram publicados utilizando a sinterização em duas etapas para outros materiais, sucintamente descritos a seguir.

Na sinterização do $\mathrm{SiC}$ contendo $\mathrm{Y}_{2} \mathrm{O}_{3}$ [26], os autores mostraram que quando a sinterização se processa com formação de fase líquida a densidade no primeiro estágio deve ser mais alta, em torno de $85 \%$ da densidade teórica, para que ocorra densificação no segundo estágio.

Young-IL Lee e colaboradores também estudaram cerâmicas de SiC utilizando a sinterização em duas etapas, obtendo tamanhos de grãos de $\sim 40$ $n m[27]$.

$\mathrm{Na}$ sinterização do $\mathrm{BaTiO}_{3}$ [28], apesar de alta densificação ter sido obtida, os autores verificaram que houve pequeno crescimento dos grãos na segunda etapa de sinterização.

Anton Polotai e colaboradores combinaram a sinterização com taxa rápida, sinterização com taxa controlada e sinterização em duas etapas para o 
$\mathrm{BaTiO}_{3}$ e conseguiram obter rápida densificação sem crescimento de grãos [29].

X. -H. Wang e colaboradores utilizando a sinterização em duas etapas para cerâmicas de $\mathrm{BaTiO}_{3}$ e ferrita de Ni-Cu-Zn obtiveram densidades de $98 \mathrm{e}$ $96 \%$ e tamanho de grãos de 70 e $35 \mathrm{~nm}$, respectivamente [30].

X. $-\mathrm{H}$. Wang e colaboradores também mostraram que uma densidade de $75 \%$ da densidade teórica (DT) é necessária na primeira etapa de sinterização, para obter a densificação sem crescimento de grãos na segunda etapa de sinterização [31]. Este valor indicaria a temperatura mínima, enquanto que a temperatura máxima é selecionada, arbitrariamente, levando em conta que o tamanho médio de grãos é determinado nesta primeira etapa.

Também foi feita a sinterização em duas etapas para $\circ \mathrm{Si}_{3} \mathrm{~N}_{4}$, para 0 qual foi obtido um material denso e isento de fases secundárias [32].

Alguns trabalhos na literatura de ampla divulgação são, ao menos aparentemente contraditórios, como exemplificado a seguir para a alumina e para a zircônia estabilizada com ítria.

Jiangong Li e Yinping Ye utilizaram o método de sinterização em duas para $\mathrm{Al}_{2} \mathrm{O}_{3}$ e obtiveram amostras com $95 \%$ DT e tamanhos de grãos de $70 \mathrm{~nm}$ [33], mas a densidade relativa na primeira etapa foi de $82 \%$.

O mesmo foi realizado em outro estudo e, como resultado, os autores mostraram que amostras com densidade menor que 92\% DT na primeira etapa, não eram possíveis de densificar mesmo com tratamento longos na segunda etapa de sinterização [34]. Uma possível explicação para isto está nos pós de partida, pois estes autores empregaram materiais de partida com características bastante diferentes.

Z. R. Hesabi e colaboradores conseguiram obter cerâmicas densas e com grãos com tamanhos sub-micrométricos ( $150 \mathrm{~nm}$ ) utilizando a sinterização em duas etapas para a $\mathrm{Al}_{2} \mathrm{O}_{3}$ [35]. Neste caso, também o material de partida tinha características diferentes dos anteriores. Os autores, entretanto, propuseram que a discrepância encontra-se na microestrutura do compacto a verde, devido ao método diferente de compactação. Especificamente, a homogeneidade no tamanho e na distribuição de tamanho de poros foram apontados como fatores importantes na obtenção de grãos reduzidos na segunda etapa de sinterização. 
C. L. -Robert e colaboradores utilizaram o método de sinterização em duas etapas para a zircônia estabilizada com $8 \% \mathrm{em} \mathrm{mol} \mathrm{de} \mathrm{ítria} \mathrm{obtida} \mathrm{pelo}$ método Pechini modificado. Os autores conseguiram uma densidade $>98 \%$ DT com tamanho médio de grãos de $5 \mu \mathrm{m}$ [36].

Minfang Han e colaboradores estudaram a zircônia estabilizada com ítria (YSZ) obtida por "tape casting", "tape calendaring" e "gel casting", onde grãos micrométricos foram obtidos utilizando a sinterização em duas etapas [37].

Abhijit Ghosh e Ashok K. Suri também utilizaram a sinterização em duas etapas para a zircônia estabilizada com $8 \% \mathrm{em}$ mol de ítria, neste caso, obtida pelo método de co-precipitação, e alcançaram $97 \%$ da DT com tamanho de grãos de 150-220 nm [38].

Mazaheri e colaboradores também utilizaram a sinterização em duas etapas para a zircônia estabilizada com $8 \% \mathrm{em}$ mol de ítria obtida por processo químico. Como resultados mais relevantes obtiveram aumento na tenacidade a fratura e diminuição do tamanho de grão [39, 40].

Z. R. Hesabi e colaboradores obtiveram resultados similares para a zircônia estabilizada com $8 \%$ em mol de ítria, mas nesse caso também ocorreu aumento na condutividade elétrica [41].

Muccillo e Muccillo [42] utilizaram o método de sinterização em duas etapas para a zircônia-8\% mol ítria comercial e obtiveram cerâmicas com alta densidade relativa (> 97\% DT) e tamanho de grãos sub-micrométricos, com diminuição da condutividade dos contornos de grão atribuído ao aumento da área de interface. Foi observado crescimento de grãos no segundo estágio de sinterização. Ao contrário dos trabalhos precedentes, neste caso, foi utilizado o material comercial.

Mazaheri e colaboradores mostraram que para a obtenção de cerâmicas densas de $\mathrm{ZnO}$, sem crescimento de grão no segundo estágio de sinterização, é necessário obter densidade inicial de 78\% DT [43].

Mazaheri e colaboradores estudaram o papel da combinação da transformação de fase do rutilo para anatase e a sinterização em duas etapas, no crescimento de grãos e na evolução da microestrutura de nanocerâmicas de $\mathrm{TiO}_{2}$ [44]. O menor tamanho de grão $(\sim 250 \mathrm{~nm})$ obtido foi para uma amostra contendo $98 \%$ de fase rutilo após a primeira etapa de sinterização. 
Zicheng Li e colaboradores estudaram o comportamento da alumina com $\mathrm{MgO}-\mathrm{CaO}-\mathrm{SiO}_{2}$ obtido por sol-gel sinterizado em duas etapas. Os autores conseguiram suprimir o crescimento de grão e obter densidade $>99 \%$ da DT [45].

Binner e colaboradores [46, 47] também tiveram sucesso no uso do método de duas etapas para a obtenção de cerâmicas de zircônia-3\% mol ítria densas contendo grãos nanométricos. Esta última característica, entretanto, mostrou ser dependente dos materiais de partida. Além disso, os autores também observaram que há um crescimento de grão, ainda que limitado, no segundo estágio de sinterização. Foi utilizada, neste caso, uma sinterização híbrida convencional e em forno de microondas.

P. C. Yu e colaboradores mostraram o efeito da sinterização em duas etapas na zircônia estabilizada com $3 \%$ mol de ítria produzida por moldagem de injeção. Nesse caso ocorreu melhora nas propriedades mecânicas [48].

Abhijit Ghosh e colaboradores correlacionaram a condutividade elétrica e a microstrutura da zircônia estabilizada com 3\% em mol de ítria na sinterização em duas etapas. O novo método de sinterização foi benéfico para a microestrutura das amostras. Os resultados foram similares para a zircônia-8\% mol ítria [49].

Mazaheri e colaboradores observaram que para obter cerâmicas de zircônia estabilizada com $3 \%$ em mol de ítria densas e suprimir o crescimento de grãos no segundo estágio de sinterização é necessário obter 83\% DT no primeiro estágio de sinterização [50].

S. Hwan Jo e colaboradores concluíram que a temperatura da segunda etapa de sinterização desempenha papel crítico para obter alta densificação nas amostras. Os autores obtiveram amostras de $\mathrm{Ce}_{0,9} \mathrm{Gd}_{0,1} \mathrm{O}_{1,95}$ com densidade de $93 \%$ DT e tamanhos de grãos nanometricos ( $72 \mathrm{~nm}$ ) [51]. Foi utilizado, como material de partida, uma solução sólida comercial com elevada área de superfície específica $\left(\sim 176,5 \mathrm{~m}^{2} \cdot \mathrm{g}^{-1}\right)$.

A. Rafferty e colaboradores utilizaram o método de sinterização em duas etapas para a ferrita de cobalto. Os autores conseguiram obter 96\% DT [52].

C. M. Lapa e colaboradores caracterizaram a céria-gadolínia com e sem adição de Ga por sinterização em duas etapas. Eles mostraram ser possível obter cerca de $92 \%$ da DT e grãos com tamanhos sub-micrométricos [53]. 
Segundo os autores a performance deste material combinando a síntese química e a sinterização em duas etapas, não trouxe benefícios com relação aos materiais comerciais e nem com relação ao tamanho de grãos.

Karel Maca e colaboradores mostraram que a eficiência do método de sinterização em duas etapas foi mais dependente da estrutura cristalina do que do tamanho de partícula e microestrutura dos corpos a verde. Os autores concluíram que o método foi mais benéfico para a zircônia cúbica do que para a alumina e a zircônia tetragonal [54].

G. S. Godoi e D. P. F de Souza utilizaram o método de sinterização em duas etapas para céria contendo zircônia e ítria e conseguiram obter densidades $>95 \%$ DT e melhora na condutividade elétrica, mas com tratamentos em temperaturas elevadas $\left(>1500^{\circ} \mathrm{C}\right)$ [55].

O método de sinterização em duas etapas foi utilizado para vários materiais por diversos autores, onde em alguns casos foi possível obter cerâmicas densas e inibir o crescimento de grãos, além de melhoras nas propriedades mecânicas. Em muitos trabalhos o método inicialmente proposto por Chen e Wang [21] foi modificado (taxa de aquecimento/resfriamento ou temperaturas e tempos de patamares ou utilizado de forma conjunta a outro método), de forma a aperfeiçoar o método para o material em estudo. A sinterização em duas etapas também foi utilizada com outros intuitos como, por exemplo, estabilizar uma fase específica. Em alguns casos, o método da sinterização em duas etapas não foi satisfatório. Nestes casos, vários parâmetros podem exercer alguma influência, como: material de partida, método de síntese, métodos de conformação, parâmetros específicos da sinterização (taxas de aquecimento e resfriamento, atmosfera) etc.

\subsection{Técnicas de Caracterização}

Serão a seguir brevemente descritas as técnicas de caracterização utilizadas neste trabalho.

\section{Termogravimetria (TG)}

$\mathrm{Na}$ termogravimetria a variação da massa é determinada como função da temperatura ou do tempo, quando uma substância específica é submetida a 
um programa controlado de temperatura. As curvas de variação de massa em função da temperatura permitem tirar conclusões sobre a estabilidade térmica da amostra, sobre a composição e estabilidade dos compostos intermediários e sobre a composição do resíduo [56].

\section{Dilatometria}

A dilatometria mede a variação no comprimento de uma amostra, durante o aquecimento e resfriamento.

O dilatômetro é utilizado para estudar a dependência entre a dilatação térmica linear e a temperatura de corpos sólidos, tais como: metais, ligas, materiais cerâmicos, vidros, minerais, plásticos e outros.

Esta técnica é muito útil no estudo do comportamento de materiais, como por exemplo, a retração de uma cerâmica à verde durante o processo de sinterização, a temperatura de transição vítrea e a cinética de transformações de fase no estado sólido [57].

Normalmente pode-se variar a taxa de aquecimento e resfriamento, assim como trabalhar em diferentes atmosferas, tais como: ar, vácuo, argônio, hélio, hidrogênio e outros $[57,58]$.

Utilizando a dilatometria pode-se avaliar o comportamento da densidade do compacto sinterizado através da Equação (7) [14]:

$$
D_{S}=\frac{D_{V}}{\left(1-\frac{\Delta L}{L_{o}}\right)^{3}}
$$

onde:

$D_{s}$ é a densidade do compacto sinterizado

$D_{v}$ é a densidade a verde

$\Delta \mathrm{L}$ é a variação da retração

$L_{o}$ é o comprimento inicial 


\section{Densidade Aparente}

A densidade aparente de um material é definida como a sua massa dividida pelo volume ocupado por esta massa. Esta propriedade pode ser determinada por diferentes técnicas. As de interesse neste trabalho são:

\section{Método Geométrico}

Esse método consiste na determinação da massa e das dimensões das amostras.

Método de imersão

Este método utiliza o princípio de Arquimedes. Neste caso, as amostras são imersas em um líquido, preferencialmente a água destilada, e fervidas por $2 \mathrm{~h}$. As amostras são resfriadas ao ar. Após o resfriamento, são realizadas as medidas de massa imersa e massa úmida. Em seguida é feita a secagem na estufa e novamente as amostras são pesadas, para a determinação da massa seca. Utilizando a equação (8), é possível obter a densidade aparente das amostras.

$$
d_{H}=\left[\left(d_{L} \cdot m_{s}\right)-\left(d_{A R} \cdot m_{i}\right)\right] /\left(m_{u}-m_{i}\right)
$$

onde:

$\mathrm{d}_{\mathrm{H}}$ densidade hidrostática ;

$\mathrm{d}_{\mathrm{L}}$ : densidade do líquido utilizado;

$d_{A R}$ : densidade do ar.

$\mathrm{m}_{\mathrm{s}}$ : massa seca;

$\mathrm{m}_{\mathrm{u}}$ : massa úmida;

$\mathrm{m}_{\mathrm{i}}$ : massa imersa;

Quando a amostra não possui poros abertos, $m_{u}=m_{s}$.

Difração de raios $X$

Os raios $\mathrm{X}$ foram descobertos pelo físico alemão Wihelm Conrad Roentgen em 1895, acidentalmente ao fazer experimentos com tubos a vácuo. 
Os raios $X$ receberam esta denominação porque a sua natureza era então desconhecida.

Um padrão ou perfil de difração de raios $X$ consiste de um conjunto de picos, cada um com diferentes posições angulares e intensidades, que são característicos para cada material [5].

A difração de raios $X$ é uma técnica que permite a identificação de fases cristalinas, realizar analise quantitativa, determinar o parâmetro de rede, determinar a estrutura cristalina e determinar tamanho de cristalito, dentre outros.

Esta técnica consiste na detecção de um feixe de raios $X$ difratado após incidir sobre o material. Quando os átomos estão regularmente espaçados em uma rede cristalina e a radiação incidente tem a mesma ordem de grandeza deste espaçamento, ocorrerá a difração desta radiação, sendo as interações construtivas descritas pela equação $(9)[5,59]$.

$$
\mathrm{n} \lambda=2 \mathrm{~d} \operatorname{sen} \theta
$$

$\mathrm{n}=$ número inteiro de comprimentos de onda

$\lambda=$ comprimento de onda da radiação incidente

d = espaçamento interplanar

$\theta$ - ângulo de incidência da radiação

Em geral, a análise de fases num material é feita por comparação com os dados existentes num banco de dados (JCPDS ou ICDD).

\section{Microscopia Eletrônica de Varredura}

Muitas das propriedades dos materiais são, em ultima análise, determinadas pelas suas respectivas microestruturas, isto é, pelos defeitos e constituintes microestruturais que eles contêm.

A importância do conhecimento e das análises quantitativas da microestrutura tem levado a um contínuo desenvolvimento das técnicas experimentais, particularmente da microscopia [57].

O Microscópio Eletrônico de Varredura (MEV) é utilizado para o estudo direto da superfície de objetos sólidos. Uma imagem é formada pela varredura 
de um feixe de elétrons que é gerado e focado pelo microscópio. A interação do feixe de elétrons com a superfície da amostra resulta na emissão de elétrons secundários e raios $X$ característicos. Os elétrons gerados pela interação do feixe com a amostra são divididos em três tipos: retroespalhados, secundários e Auger, sendo os elétrons secundários os mais importantes para a formação da imagem. Esses elétrons são formados pela excitação de elétrons fracamente ligados ao núcleo, devido à interação com elétrons primários ou elétrons espalhados de qualquer tipo [60]. Ele possui uma profundidade de foco muito maior que o microscópio ótico e, por essa razão, o MEV pode gerar uma imagem que é boa representação tridimensional da superfície da amostra.

\section{Determinação do Tamanho Médio de Grãos}

A determinação do tamanho médio de grãos nas amostras polidas e atacadas termicamente é, geralmente, feita pelo método de Mendelson [61], ou método dos interceptos. O tamanho médio de grãos $(G)$ é dado pelo produto entre a média dos interceptos medidos e uma constante de proporcionalidade. A equação para a determinação do tamanho médio de grãos é dada por [61]:

$$
G=1,56 \bar{e}
$$

onde:

$\mathrm{G}$ = tamanho médio dos grãos;

$\bar{e}=$ distância média dos interceptos.

Como em toda análise quantitativa é muito importante ter uma boa estatística. Neste caso, a análise de diversas micro-regiões de uma dada amostra deve ser feita, de modo a serem analisados cerca de 500 a 1000 grãos.

Espectroscopia de Impedância

As medidas de espectroscopia de impedância no estudo de eletrólitos sólidos foram inicialmente utilizadas por Bauerle [62] em 1969, para a zircônia- 
ítria. Ele demonstrou, experimentalmente, que o diagrama de impedância de uma cerâmica policristalina é constituído por três semicírculos. O semicírculo na região de altas frequências está relacionado à condutividade no interior dos grãos; o semicírculo na região de frequências intermediárias está relacionado às reações nas interfaces do eletrólito (contornos de grão) e, o semicírculo na região de baixas frequências está relacionado às reações da interface eletrólito-eletrodo.

A figura 6 mostra um diagrama de impedância idealizado contendo os três semicírculos, no qual é plotado o componente imaginário, - Z", da impedância em função do componente real, Z'.

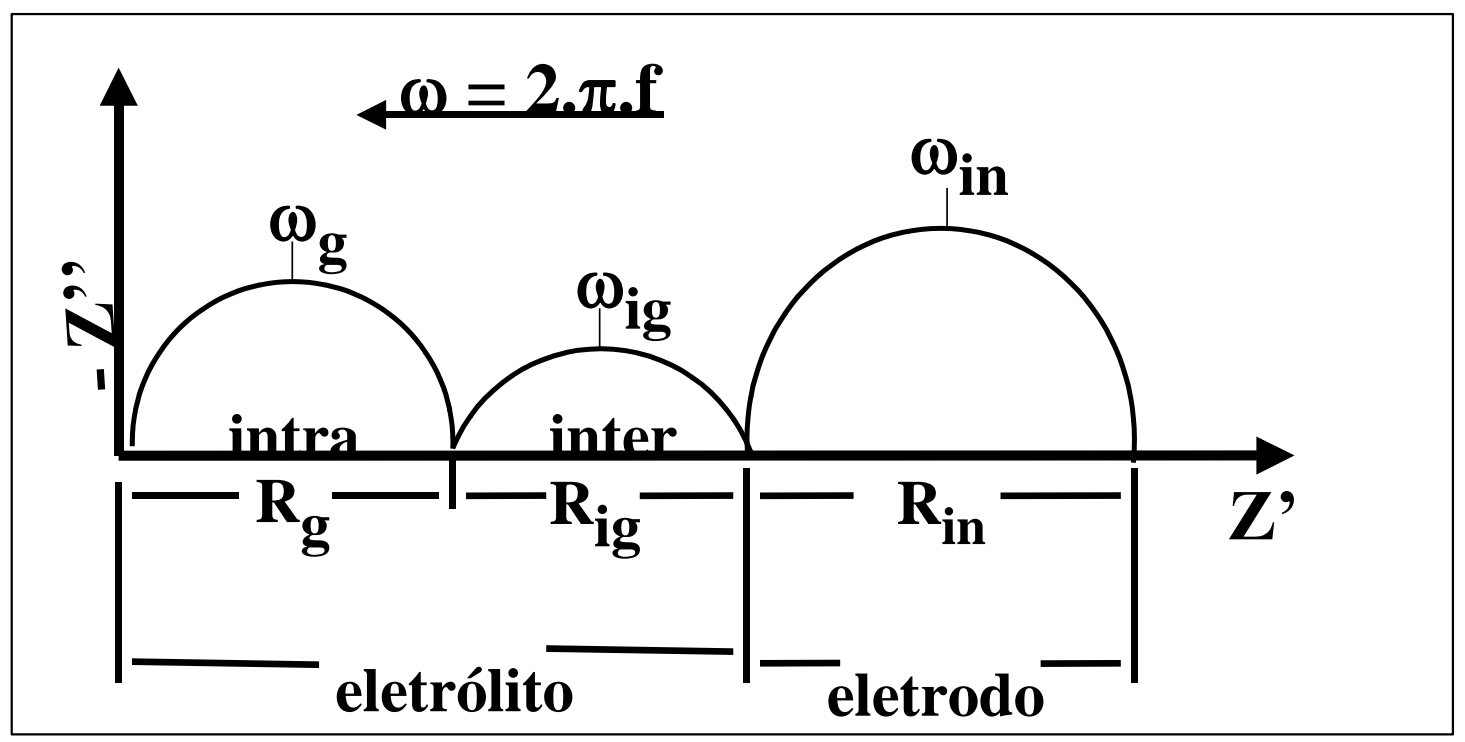

Figura 6: Diagrama de impedância idealizado contendo três semicírculos.

Na figura $6, R$ representa a resistência intragranular $\left(R_{g}\right)$, intergranular $\left(R_{\text {ig }}\right)$, e interfacial eletrólito-eletrodo $\left(R_{\text {in }}\right)$ e $\omega_{\mathrm{g}}, \omega_{\text {ig }}$ e $\omega_{\text {in }}$ representam as freqüências angulares, e a seta indica o sentido do aumento da frequência (f).

\section{Condutividade Elétrica}

A resistência das amostras, determinada por medidas de espectroscopia de impedância, pode ser facilmente relacionada com a resistividade $(\rho)$ ou com a condutividade elétrica $(\sigma)$ do material pelas seguintes relações: 


$$
R=\rho \frac{l}{S}
$$

onde $\quad I=$ espessura da amostra

$\mathrm{S}=$ área da amostra

A partir da resistividade elétrica é calculada a condutividade elétrica:

$$
\rho=\frac{1}{\sigma}
$$

A dependência da condutividade elétrica com a temperatura pode ser obtida pela seguinte equação:

$$
\sigma=\frac{\sigma_{o}}{T} \exp \left(-\frac{E}{k T}\right)
$$

onde:

$\sigma_{0}=$ fator pré-exponencial

$E=$ energia de ativação aparente para o processo de condução

$\mathrm{k}=$ constante de Boltzmann

$\mathrm{T}=$ temperatura absoluta

A condutividade elétrica total dos sólidos é dada pela soma das contribuições de todos os portadores de carga presentes. Se o sólido contiver diferentes tipos de portadores, a condutividade pode ser relacionada com cada portador de carga. A condutividade elétrica é dada pela soma da condutividade eletrônica e iônica segundo a equação (14) [4].

$$
\sigma=\sigma_{e l}+\sigma_{i o n}
$$

onde:

$\sigma=$ condutividade elétrica total

$\sigma_{e l}=$ condutividade eletrônica

$\sigma_{i o n}=$ condutividade iônica 
Para condutores iônicos, a contribuição da condutividade eletrônica deve ser desprezível, ou melhor, a razão entre as condutividades iônica e eletrônica deve ser muito elevada. 


\section{MATERIAIS E MÉTODOS}

Neste capítulo serão descritos os materiais utilizados neste trabalho e os métodos empregados para a elaboração das amostras e sua caracterização.

\section{Materiais}

Foram utilizados céria-samária $\left(\mathrm{Ce}_{0,8} \mathrm{Sm}_{0,2} \mathrm{O}_{1,9}\right)$, e céria-samária obtida através de mistura de óxidos seguida de reações em estado sólido. O material preparado por mistura dos óxidos precursores teve a mesma estequiometria da solução sólida comercial.

$\mathrm{Na}$ tabela $\mathrm{V}$ são mostradas algumas características dos materiais de partida.

Tabela V - Características físicas e químicas dos materiais de partida [3].

\begin{tabular}{|c|c|c|c|}
\hline & $\begin{array}{l}\text { Óxido de } \\
\text { Samário }\end{array}$ & $\begin{array}{c}\text { Óxido de } \\
\text { Cério }\end{array}$ & Ceria-samária \\
\hline \multicolumn{4}{|l|}{ Massa } \\
\hline Molecular (g/mol) & 348,70 & 172,12 & 580,82 \\
\hline \multicolumn{4}{|l|}{ Densidade } \\
\hline$\left(\mathrm{g} / \mathrm{cm}^{3}\right)$ & 7,09 & 7,216 & $7,14^{*}$ \\
\hline $\begin{array}{l}\text { Temperatura } \\
\text { de fusão }\left({ }^{\circ} \mathrm{C}\right)\end{array}$ & 2269 & 2400 & ------------------ \\
\hline \multicolumn{4}{|l|}{ Pureza } \\
\hline$(\%)$ & 99,9 & 99,9 & ------------------- \\
\hline Fornecedor & Aldrich & Aldrich & Fuel cell materials \\
\hline
\end{tabular}

$\mathrm{Na}$ tabela VI estão relacionados os códigos envolvendo as condições utilizadas neste trabalho. 
Tabela VI - Lista de códigos utilizados.

\begin{tabular}{lc}
\hline \multicolumn{1}{c}{ Condições } & Código \\
\hline Céria-samária comercial & SDC1 \\
Céria-sámaria obtida por mistura de óxidos & SDC2 \\
Sinterização em duas etapas [38] & TSS \\
Sinterização em duas etapas "tradicional" & TSS-t \\
Temperatura do primeiro patamar & $\mathrm{T}_{1}$ \\
Temperatura do segundo patamar & $\mathrm{T}_{2}$ \\
Tempo do primeiro patamar & $\mathrm{t}_{1}$ \\
Tempo do segundo patamar & $\mathrm{t}_{2}$ \\
\hline
\end{tabular}

Neste estudo a temperatura do primeiro patamar, $T_{1}$, será também chamada de temperatura de pico, pois a temperatura do segundo patamar foi sempre inferior a esta, e o tempo de patamar $\left(\mathrm{t}_{1}\right)$ foi igual a $0 \mathrm{~h}$.

\section{Métodos}

Elaboração das amostras

Para a obtenção de corpos de prova foram pesadas quantidades estequiométricas de $\mathrm{CeO}_{2}: \mathrm{Sm}_{2} \mathrm{O}_{3}$ (SDC1) e de $\mathrm{CeO}_{2}$ e $\mathrm{Sm}_{2} \mathrm{O}_{3}$ (SDC2). Foi utilizada para pesagem, uma balança analítica Mettler modelo H315.

Partindo-se dos óxidos precursores foi feita a mistura utilizando um misturador mecânico (Túrbula, T2C) com meios de moagem de zircônia tetragonal policristalina em meio alcoólico por $5 \mathrm{~h}$. A mistura foi colocada numa estufa a $40{ }^{\circ} \mathrm{C}$ durante 5 dias. Em seguida, foi feita a mistura do material a seco em um misturador mecânico (Túrbula, T2C) por $1 \mathrm{~h}$. Esse procedimento teve por finalidade minimizar a formação de aglomerados que podem surgir durante a secagem, após a mistura em meio líquido.

Quantidades convenientes $(\sim 0,6 \mathrm{~g})$ dos pós SDC1 e SDC2 foram conformados por prensagem uniaxial em matriz metálica de $10 \mathrm{~mm}$ com pressão de $38 \mathrm{MPa}$, seguido de compactação isostática a frio ( 138 MPa).

As amostras foram sinterizadas utilizando o processo de sinterização em duas etapas (TSS), figura 7 e sinterização em duas etapas tradicional (TSS-t), figura 8. As taxas de aquecimento foram de $2{ }^{\circ} \mathrm{C} / \mathrm{min}$ para a solução sólida 
comercial (SDC1) e $10{ }^{\circ} \mathrm{C} /$ min para o material obtido por mistura de óxidos (SDC2), e para o resfriamento $10^{\circ} \mathrm{C} / \mathrm{min}$. Para as sinterizações foi utilizado o forno resistivo Lindberg tipo caixa.

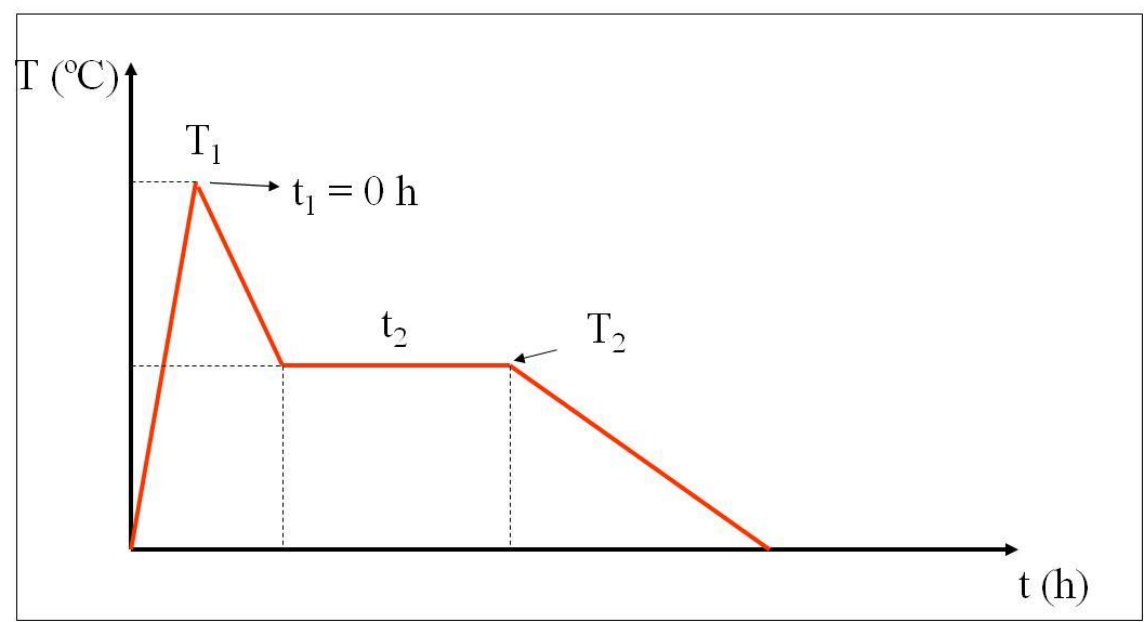

Figura 7: Representação do perfil temperatura-tempo no processo de sinterização em duas etapas.

Na sinterização em duas etapas (figura 7) a amostra é inicialmente conduzida a uma alta temperatura $\left(T_{1}\right)$ por tempo pequeno ou nulo $\left(t_{1}\right)$, sendo em seguida resfriada rapidamente até uma temperatura inferior $\left(T_{2}\right)$ na qual permanece por um tempo específico $\left(\mathrm{t}_{2}\right)$.

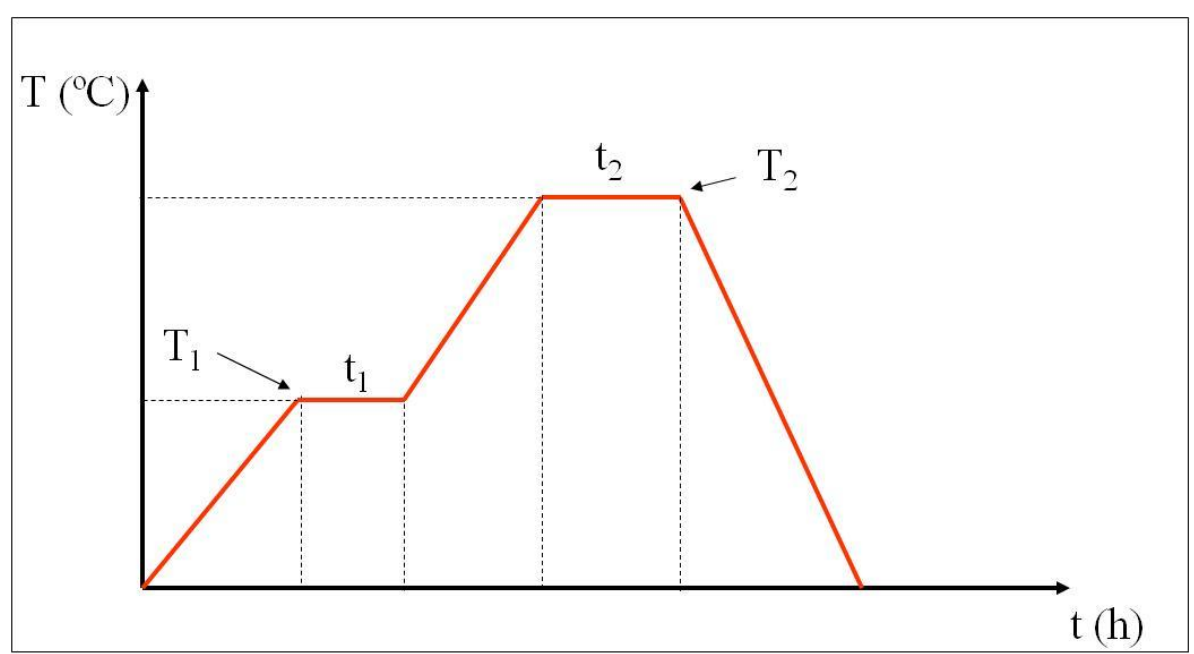

Figura 8: Representação do perfil temperatura-tempo no processo de sinterização em duas etapas tradicional.

$\mathrm{Na}$ sinterização em duas etapas tradicional (figura 8) a amostra é conduzida à temperatura $\left(T_{1}\right)$, relativamente baixa, por tempo especifico $\left(t_{1}\right)$, 
sendo em seguida aquecida até uma temperatura $\left(\mathrm{T}_{2}\right)$ na qual permanece por um tempo específico $\left(t_{2}\right)$, em geral bem maior do que $t_{1}$.

É importante ressaltar que a sinterização em duas etapas, como proposta inicialmente, requer altas taxas de aquecimento e resfriamento, o que não foi possível para este material. Foram feitos testes iniciais com taxas de aquecimento iguais a $10,8,5$ e $2^{\circ} \mathrm{C} / \mathrm{min}$. Somente neste último caso $\left(2{ }^{\circ} \mathrm{C} /\right.$ min) os compactos preparados com a solução sólida comercial não trincaram.

\section{Caracterização das amostras}

A área de superfície específica do pó obtido por mistura de óxidos (SDC2) foi estimada por adsorção gasosa de $N_{2}$, pelo método de $B E T$, utilizando o equipamento Quantachrome Nova-1200. Para a solução sólida comercial (SDC1) o valor da área de superfície específica foi fornecido pelo fabricante.

O estudo do comportamento térmico do material comercial (SDC1) foi realizado por análise termogravimétrica (TG) em uma termobalança (modelo STA 409, Netzsch), com taxa de aquecimento de $10^{\circ} \mathrm{C} / \mathrm{min}$ até $1500^{\circ} \mathrm{C}$, e sob fluxo de ar sintético.

A retração linear de compactos preparados com ambos pós foi verificada em dilatômetro (Setaram modelo Labsys) do CCCH/IPEN, com taxa de aquecimento de $10 \stackrel{\circ}{\circ} / \mathrm{min}$ até a temperatura de $1400^{\circ} \mathrm{C}$, em atmosfera estática de ar sintético. Neste caso, as amostras foram preparadas por compactação uniaxial em matriz metálica de $5 \mathrm{~mm}$ com pressão de $50 \mathrm{MPa}$, seguido de compactação isostática a frio ( 138 MPa).

Após a sinterização as amostras foram caracterizadas por medidas de densidade aparente sinterizada, difração de raios $X$, observação da microestrutura em microscópio eletrônico de varredura e medidas da condutividade elétrica.

Inicialmente foi determinada a densidade aparente das amostras através do método geométrico e utilizando o princípio de Arquimedes. As dimensões das amostras foram determinadas por micrômetro da marca Tesa. Foram feitas 10 medidas de diâmetro e 10 de espessura, para obter precisão adequada neste tipo de medida. Para o método de Arquimedes foram feitas medidas de 
massa seca, massa úmida e massa imersa, para cada amostra, e 10 medidas em casa caso. Para determinar a densidade, utilizou-se a equação (8). Para o cálculo da densidade relativa utilizou-se a densidade teórica da ceria-samária como sendo $7,14 \mathrm{~g} / \mathrm{cm}^{3}$ [63].

Para a verificação da formação da solução sólida nas amostras preparadas por mistura de óxidos, e confirmação da composição de fases na solução sólida comercial foram realizadas análises de difração de raios $X$ (Bruker-AXS, D8 Advance) no intervalo $20^{\circ} \leq 2 \theta \leq 80^{\circ}$, com passo de $0,05^{\circ}$, e tempo de exposição de $3 \mathrm{~s}$, utilizando a radiação $\mathrm{K}_{\alpha}$ do $\mathrm{Cu}(\lambda=1,5405 \AA$ ), e filtro de Ni. Para a verificação da solução solida foram utilizadas as fichas ICDD (34-394 e 42-1461 e JCPDS\#28792).

Para o estudo da microestrutura as amostras foram observadas utilizando elétrons secundários, em microscópio eletrônico de varredura (Philips, modelo XL30 e LEO STEREOSCAN 440). As amostras foram seccionadas, embutidas, lixadas e polidas com pastas adiamantadas até $1 \mu \mathrm{m}$. Para revelação dos contornos de grãos foi feito ataque térmico em temperatura $100 \stackrel{\circ}{C}$ inferior à da sinterização. O tamanho médio de grãos foi determinado utilizando o método dos interceptos (ou de Mendelson) [61] numa amostragem superior a 500 grãos.

Compactos sinterizados foram caracterizados com relação ao comportamento elétrico por espectroscopia de impedância. As medidas foram feitas em câmara porta-amostras de inconel inserida em forno resistivo. A temperatura foi monitorada com termopar tipo $\mathrm{K}$ (Cromel-Alumel). $\mathrm{O}$ equipamento usado foi um analisador de impedância HP 4192A, acoplado a um controlador HP 362. Os dados de medidas elétricas foram coletados e analisados por meio de programa computacional. As medidas foram realizadas na faixa de frequência de $5 \mathrm{~Hz}$ a $13 \mathrm{MHz}$, no intervalo de temperatura de 150 ${ }^{\circ} \mathrm{C}$ a $300^{\circ} \mathrm{C}$. Para estas medidas foi utilizada a prata, aplicada por pintura seguida de cura a $400^{\circ} \mathrm{C}$, como eletrodo.

Os cálculos da condutividade e da energia de ativação para o processo de condução foram feitos de acordo com as equações 11-13. 


\section{RESULTADOS E DISCUSSÃO}

Neste capitulo serão apresentados e discutidos os principais resultados obtidos na seguinte sequência: material particulado, compactos a verde e compactos sinterizados.

Os pós utilizados nesse trabalho, solução sólida comercial (SDC1) e preparada por mistura de óxidos (SDC2), foram observados em microscópio eletrônico de varredura para verificação da morfologia das partículas e aglomerados. As micrografias são mostradas na figura 9.
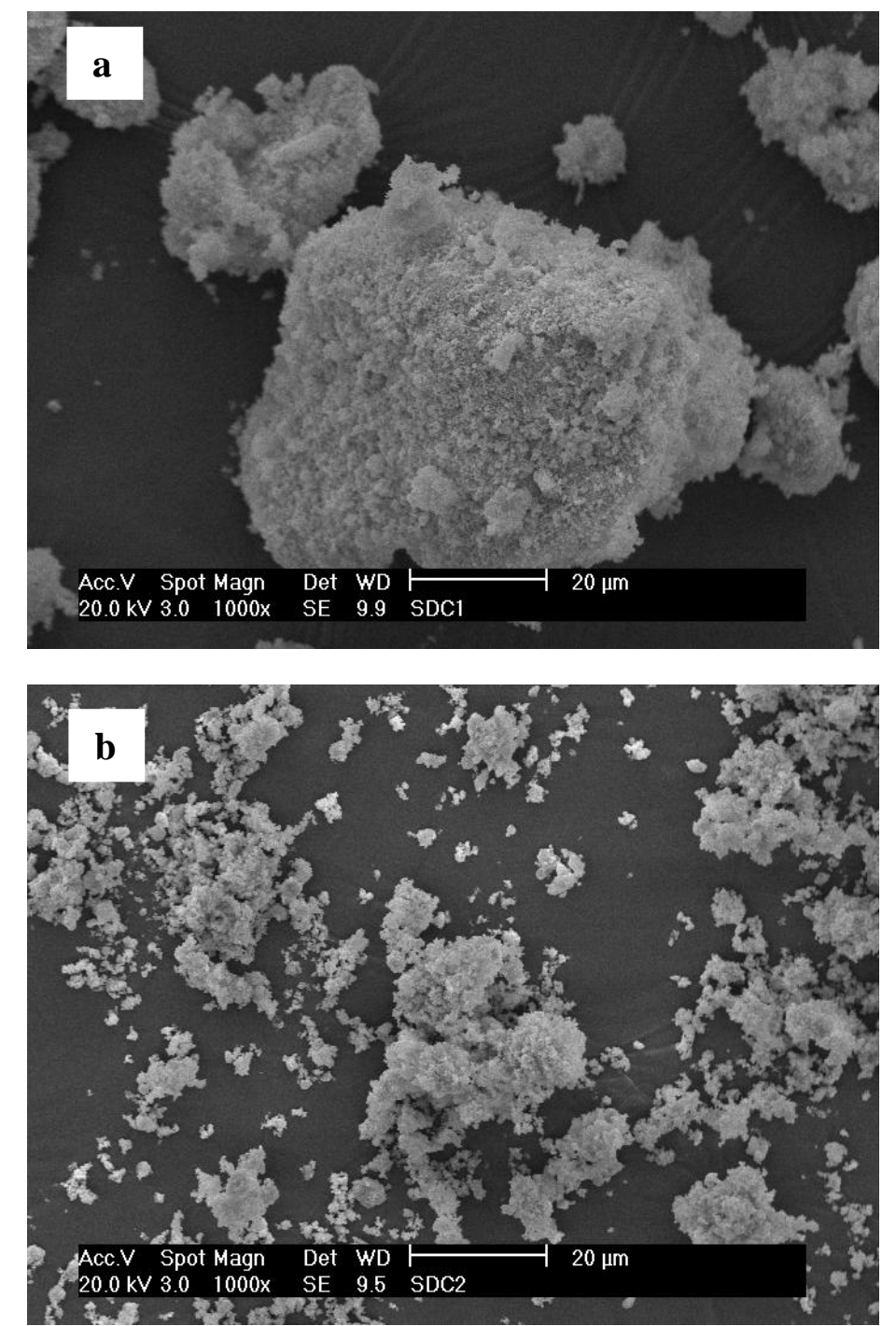

Figura 9: Micrografias obtidas por microscopia eletrônica de varredura das soluções sólidas: a) comercial (SDC1) e b) preparada por mistura de óxidos (SDC2).

Ambos os materiais particulados são constituídos por aglomerados de partículas nanométricas. Os aglomerados possuem tamanhos bastante 
distintos. O estado de aglomeração é maior na solução sólida comercial (figura 9a). Isto pode estar relacionado com os valores de área de superfície específica, que são também consideravelmente diferentes: 36,1 e $8,9 \mathrm{~m}^{2} / \mathrm{g}$, respectivamente, para a solução sólida comercial e para aquela preparada pela mistura dos óxidos.

A figura 10 mostra a curva termogravimétrica para a céria-samária comercial SDC1.

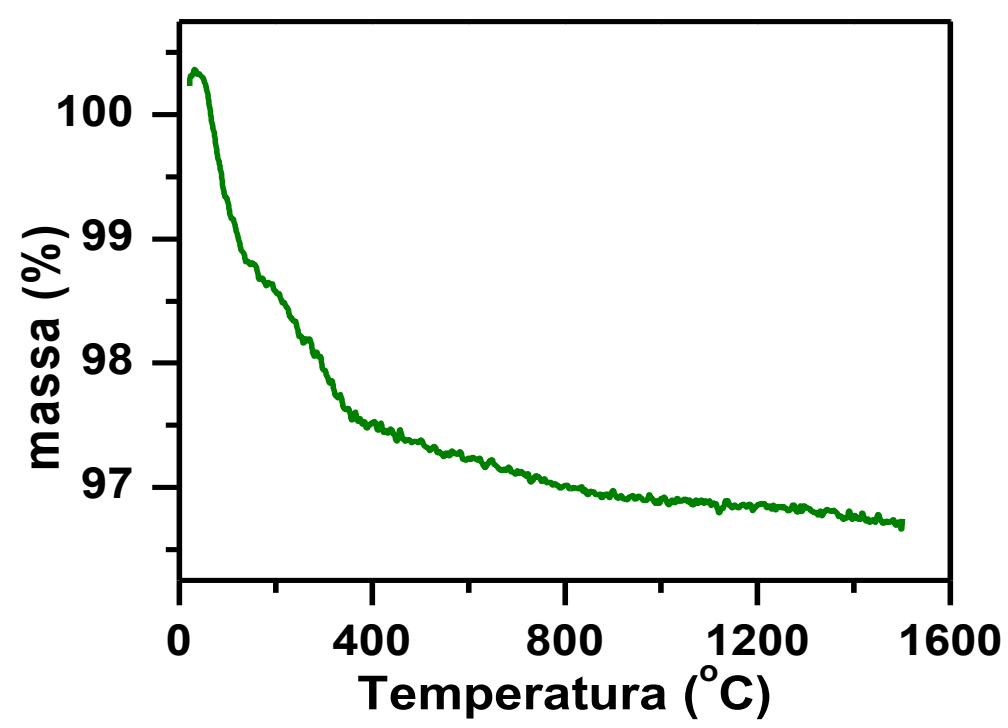

Figura 10: Curva termogravimétrica da céria-samária comercial (SDC1).

A curva termogravimétrica mostra uma perda de massa contínua de $\sim 3 \%$ até $800{ }^{\circ} \mathrm{C}$, e acima desta temperatura a variação de massa é desprezível. $\mathrm{Na}$ região de temperaturas entre 400 e $800{ }^{\circ} \mathrm{C}$ a perda de massa é inferior a $1 \%$. Esta perda de massa pode estar relacionada com algum aditivo orgânico introduzido com a finalidade de auxiliar a compactação, uma vez que as soluções sólidas à base de céria apresentam baixa sinterabilidade.

A figura 11 mostra a retração linear da céria-samária comercial SDC1 durante o ciclo de aquecimento/resfriamento realizado num dilatômetro. 


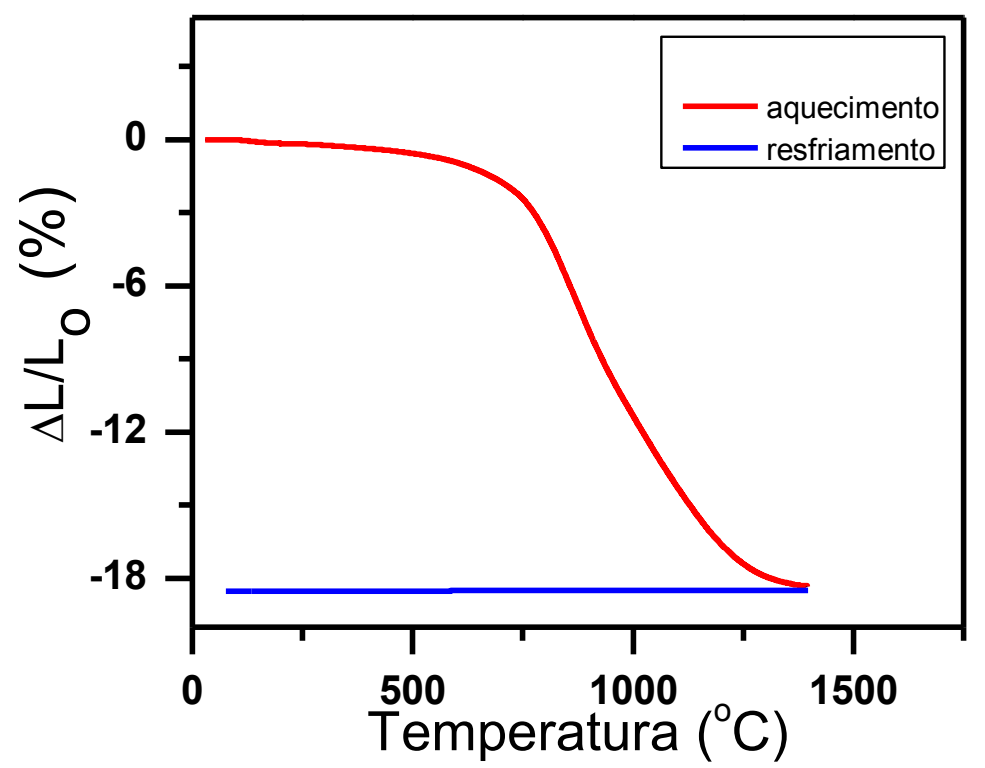

Figura 11: Retração linear da céria-samária (SDC1) durante o aquecimento e resfriamento.

A retração total obtida até $1400{ }^{\circ} \mathrm{C}$ foi de $18 \%$. A temperatura inicial de retração foi de $\sim 688^{\circ} \mathrm{C}$ e a temperatura final de retração foi de $\sim 1260{ }^{\circ} \mathrm{C}$. Não foi observada variação significativa da retração linear durante o resfriamento, como esperado, pois não ocorre transformação de fase nesta faixa de temperatura.

A máxima retração desse material foi obtida com a derivada da curva, figura 12. A derivada da curva de retração (Figura 12) mostra dois pontos de inflexão: $884{ }^{\circ} \mathrm{C}$ e $1014^{\circ} \mathrm{C}$. Como mencionado acima, a céria-samária não apresenta transformação de fase nesta faixa de temperatura, então, é possível que esta segunda inclinação (em temperatura mais alta) esteja relacionada com mudanças no mecanismo de sinterização. 


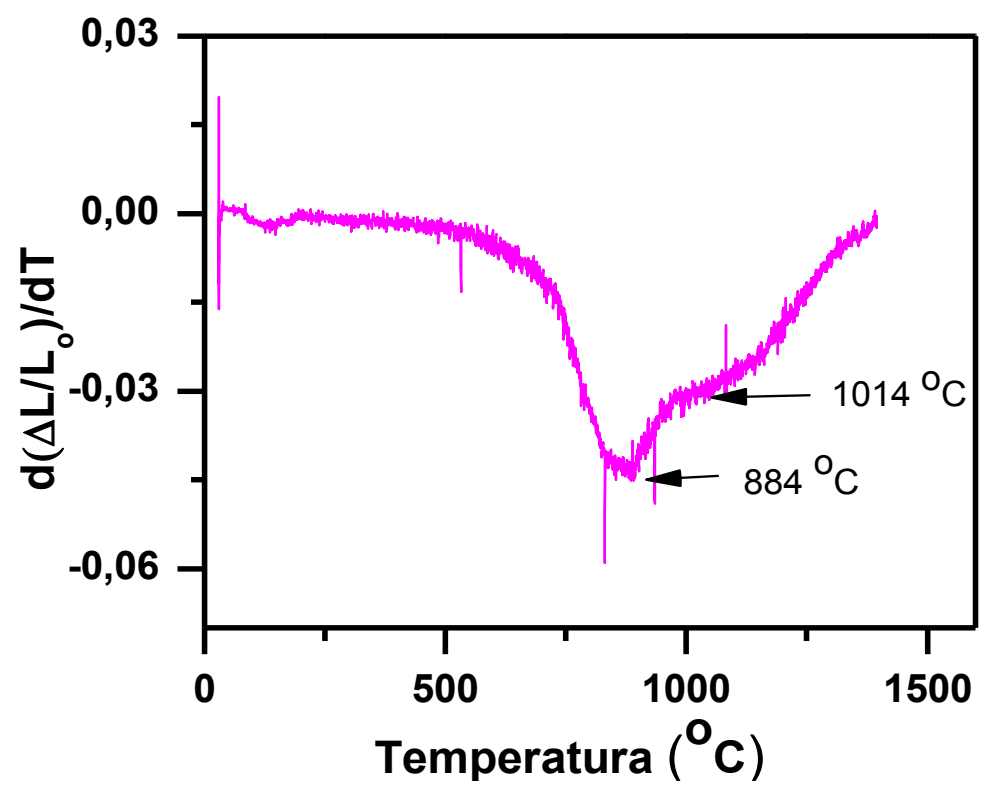

Figura 12: Derivada da curva de retração linear da céria-samária comercial (SDC1).

A figura 13 mostra o comportamento da densidade em função da temperatura, utilizando a equação (7), válida para sistemas isotrópicos [14].

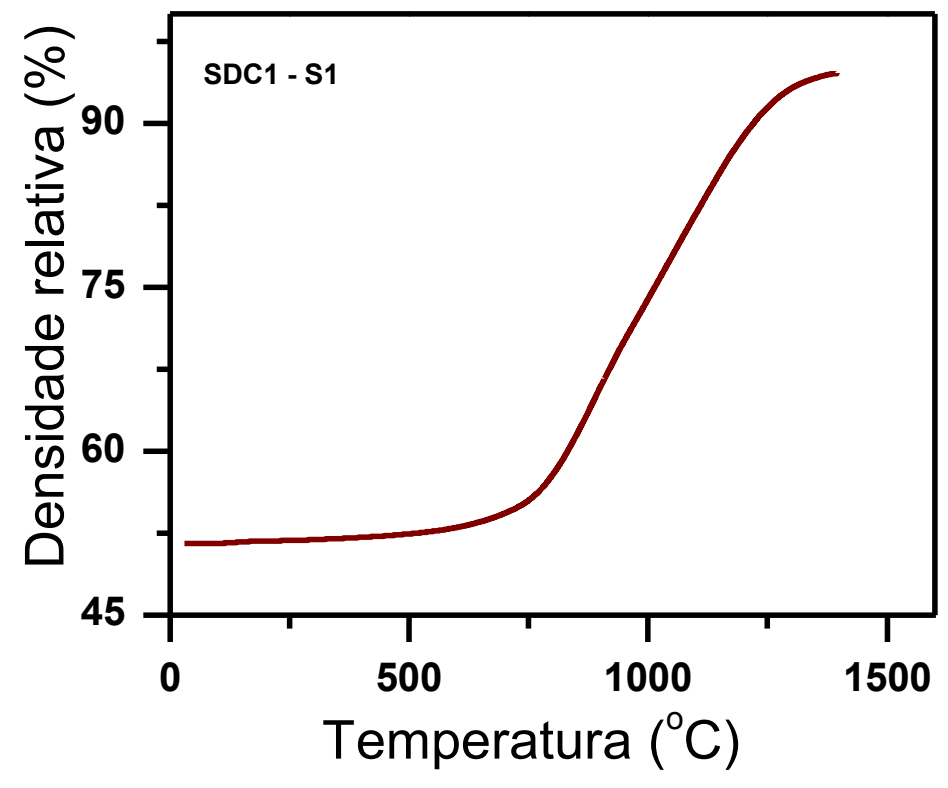

Figura 13: Curva de densidade relativa em função da temperatura de sinterização obtida a partir da retração linear.

Observa-se que até $\sim 600^{\circ} \mathrm{C}$ não há variação significativa na densidade do compacto. A $\sim 1280{ }^{\circ} \mathrm{C}$ a taxa de densificação diminui e a $\sim 1400{ }^{\circ} \mathrm{C}$ a densificação atinge seu valor máximo $94 \%$. 
A temperatura na qual o compacto atinge $75 \%$ de densidade relativa é $1016^{\circ} \mathrm{C}$. O resultado apresentado na figura 13 deve ser visto com cautela, uma vez que não foi feita correção para a perda de massa ( 3\%) que ocorre até $800 \stackrel{\circ}{\circ}$ (figura 10).

Nesse trabalho procurou-se obter amostras densas e com tamanhos de grãos controlados. Então, foram realizadas diversas sinterizações nos dois tipos de amostras (SDC1 e SDC2), onde num primeiro momento tentou-se obter compactos densos variando as condições de temperatura e tempo na sinterização.

A densidade a verde das amostras obtidas pela solução sólida comercial (SDC1) e pela solução sólida preparada por mistura de óxidos (SDC2) foi da ordem de 48 e $63 \%$ da densidade teórica, respectivamente.

A figura 14 mostra a dependência da densidade em função da temperatura de pico $\left(T_{1}\right)$ na sinterização em duas etapas para amostras SDC1 e SDC2.

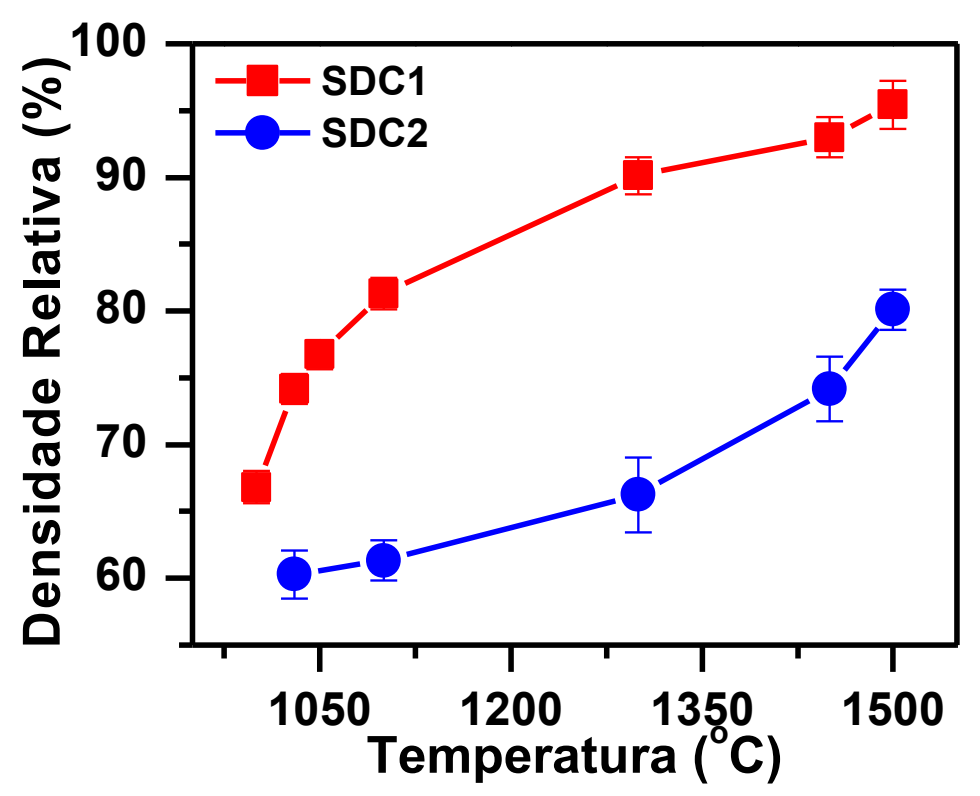

Figura 14: Densidade relativa em função da temperatura $T_{1}$ para a solução sólida comercial (SDC1) e preparada por mistura de óxidos (SDC2). Tempo de patamar $t_{1}=0 \mathrm{~h}$.

Observa-se que há um aumento gradual da densidade relativa com o aumento da temperatura de sinterização, como esperado. Entretanto, os valores de densidade obtidos para as amostras SDC1 são sempre superiores 
àqueles das amostras SDC2. Isto ocorre porque a solução sólida comercial possui maior área de superfície especifica $\left(36,1 \mathrm{~m}^{2} / \mathrm{g}\right)$ e, portanto, partículas mais finas do que a solução sólida obtida por mistura de óxidos $\left(8,9 \mathrm{~m}^{2} / \mathrm{g}\right)$. Além disso, a amostra SDC1 já é uma solução sólida, enquanto que nas amostras SDC2 parte da energia fornecida no tratamento térmico é usada para formar a solução sólida. Na temperatura de $1450 \stackrel{\circ}{\mathrm{C}}$ a densidade relativa obtida para a solução sólida comercial foi de $93 \%$ e para aquela preparada a partir da mistura dos óxidos foi de apenas $74 \%$.

A temperatura na qual o compacto SDC1 atinge $75 \%$ de densidade relativa é $\sim 1035^{\circ} \mathrm{C}$, que é pouco superior àquela $\left(1016{ }^{\circ} \mathrm{C}\right)$ obtida pela figura 13. Para a temperatura de $1400{ }^{\circ} \mathrm{C}$ a densificação atinge $92 \%$, próximo do valor obtido na figura 13.

Após a determinação da temperatura (de pico) $T_{1}=1030 \stackrel{\circ}{\circ}$, onde têmse $75 \%$ da densidade teórica, procurou-se determinar a temperatura $\left(\mathrm{T}_{2}\right)$ e 0 tempo $\left(\mathrm{t}_{2}\right)$ do segundo patamar. Nesse caso, era esperado um aumento considerável na densificação, mas isso não ocorreu, como mostram os resultados de densidade na tabela VII.

Tabela VII: Densidade relativa de amostras SDC1 sinterizadas em duas etapas.

\begin{tabular}{|c|c|c|c|}
\hline $\begin{array}{l}\text { Condições } \\
\text { oC/h }\end{array}$ & $\begin{array}{l}\text { Densidade } \\
\text { relativa (\%) }\end{array}$ & $\begin{array}{c}\text { Condições } \\
{ }^{\circ} \mathrm{C} / \mathrm{h}\end{array}$ & $\begin{array}{l}\text { Densidade } \\
\text { relativa (\%) }\end{array}$ \\
\hline $1030 / 0$ & $75,07 \pm 1,2$ & $1300 / 0$ & $89,5 \pm 0,6$ \\
\hline $1030 / 0+980 / 2$ & $76,33 \pm 0,8$ & $1300 / 0+1050 / 5$ & $91,8 \pm 0,6$ \\
\hline $1030 / 0+980 / 5$ & $77,17 \pm 0,9$ & $1300 / 0+1200 / 5$ & $92,1 \pm 0,6$ \\
\hline $1030 / 0+1000 / 5$ & $78,99 \pm 0,8$ & $1300 / 0+1250 / 5$ & $93,2 \pm 0,5$ \\
\hline $1030 / 0+1000 / 10$ & $79,69 \pm 0,8$ & $1300 / 0+1250 / 10$ & $94,4 \pm 0,5$ \\
\hline $1030 / 0+1000 / 24$ & $81,79 \pm 1,0$ & $1300 / 0+1275 / 5$ & $93,98 \pm 0,6$ \\
\hline $1050 / 0+1000 / 2$ & $77,87 \pm 1,2$ & $1450 / 0$ & $93,56 \pm 0,6$ \\
\hline $1070 / 0+1000 / 2$ & $78,85 \pm 0,7$ & $1450 / 0+1200 / 5$ & $94,26 \pm 0,7$ \\
\hline $1070 / 0+1000 / 10$ & $79,83 \pm 1,2$ & $1450 / 0+1350 / 5$ & $95,80 \pm 0,6$ \\
\hline $1100 / 0+1070 / 5$ & $84,03 \pm 1,2$ & $1450 / 0+1400 / 5$ & $95,66 \pm 0,8$ \\
\hline $1100 / 0+1070 / 24$ & $87,82 \pm 0,5$ & $1450 / 0+1425 / 5$ & $98,18 \pm 0,7$ \\
\hline $1150 / 0+1000 / 24$ & $85,71 \pm 0,7$ & & \\
\hline $1200 / 0+1050 / 5$ & $88,24 \pm 0,8$ & & \\
\hline
\end{tabular}

Como pode ser visto, nem o aumento da temperatura $T_{2}$ de 980 para $1000 \stackrel{\circ}{\circ}$, nem o aumento do tempo $t_{2}$ de 5 para $24 \mathrm{~h}$ (em negrito) resultaram em aumento substancial da densidade relativa. Assim, decidiu-se aumentar a 
temperatura $T_{1}$ procurando-se obter uma melhora na densificação. A tabela VII mostra algumas das condições utilizadas e os resultados obtidos.

Só foram obtidos resultados de densidade significativos ao utilizar $T_{1}$ igual ou superior a $1300{ }^{\circ} \mathrm{C}$. Estes resultados mostram que seria desejável utilizar taxas de aquecimento e resfriamento superiores àquelas empregadas neste trabalho. Isto evitaria a redução na área de superfície específica durante o aquecimento dos compactos e permitiria aumentar a densificação no estágio intermediário de sinterização. Entretanto, não foi possível obter amostras íntegras da solução sólida comercial, para taxas de aquecimento/resfriamento mais elevadas.

Aumentando a temperatura $T_{1}$ de 1300 para $1450{ }^{\circ} \mathrm{C}$ proporcionou um aumento de $\sim 4 \%$ na densidade relativa. Observa-se que para $T_{1}=1300{ }^{\circ} \mathrm{C} \mathrm{e}$ $\mathrm{T}_{1}=1450{ }^{\circ} \mathrm{C}$ a densidade relativa sempre aumenta com $\mathrm{T}_{2}$, apesar deste aumento ser pequeno $(\sim 2 \%)$ para $T_{1}=1300{ }^{\circ} \mathrm{C} \mathrm{e}(<4 \%)$ para $T_{1}=1450{ }^{\circ} \mathrm{C}$. Convém salientar que a densidade relativa atingida após $T_{1}=1450{ }^{\circ} \mathrm{C}$ já é suficiente para que a céria-samária possa ser utilizada em dispositivos eletroquímicos.

A figura 15 mostra o comportamento da densidade relativa para amostras preparadas pela mistura de óxidos (SDC2) sinterizadas na temperatura $T_{1}=1450 \stackrel{\circ}{\circ}$ em diferentes temperaturas $T_{2}$. 


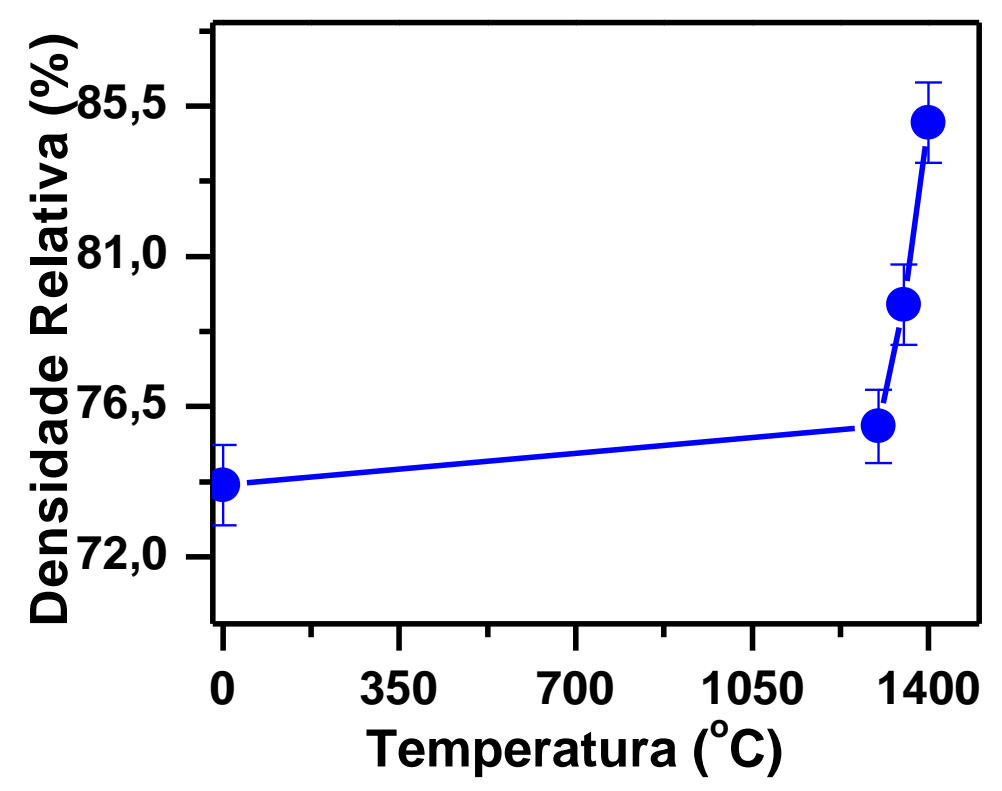

Figura 15: Densidade relativa em função da temperatura para amostras SDC2 para $T_{1}=1450{ }^{\circ} \mathrm{C} \mathrm{com} t_{1}=0 \mathrm{~h}$, e diferentes $T_{2}$ e $t_{2}=5 \mathrm{~h}$.

Observa-se que para $T_{2}$ acima de $1300{ }^{\circ} \mathrm{C}$ a densidade relativa aumenta consideravelmente. Isto deve estar relacionado com o fato da solução sólida estar quase que totalmente formada nessa temperatura [64]. Esse aumento é maior do que aquele ocorrido para as amostras SDC1 na mesma temperatura $T_{1}$. Este resultado evidencia o comportamento bastante distinto das soluções sólidas comercial e preparada pela mistura dos óxidos. Apesar dessa diferença, ambos os tipos de amostra só atingem valores de densidade significativos a partir de $1300^{\circ} \mathrm{C}$.

A figura 16 mostra a dependência da densidade relativa de amostras SDC1 na sinterização em duas etapas tradicional, TSS-t, para $T_{1}=1100{ }^{\circ} \mathrm{C}$ com tempo fixo de $1 \mathrm{~h} \mathrm{e} \mathrm{T}_{2}=1450^{\circ} \mathrm{C}$ com tempo variável até $5 \mathrm{~h}$. 


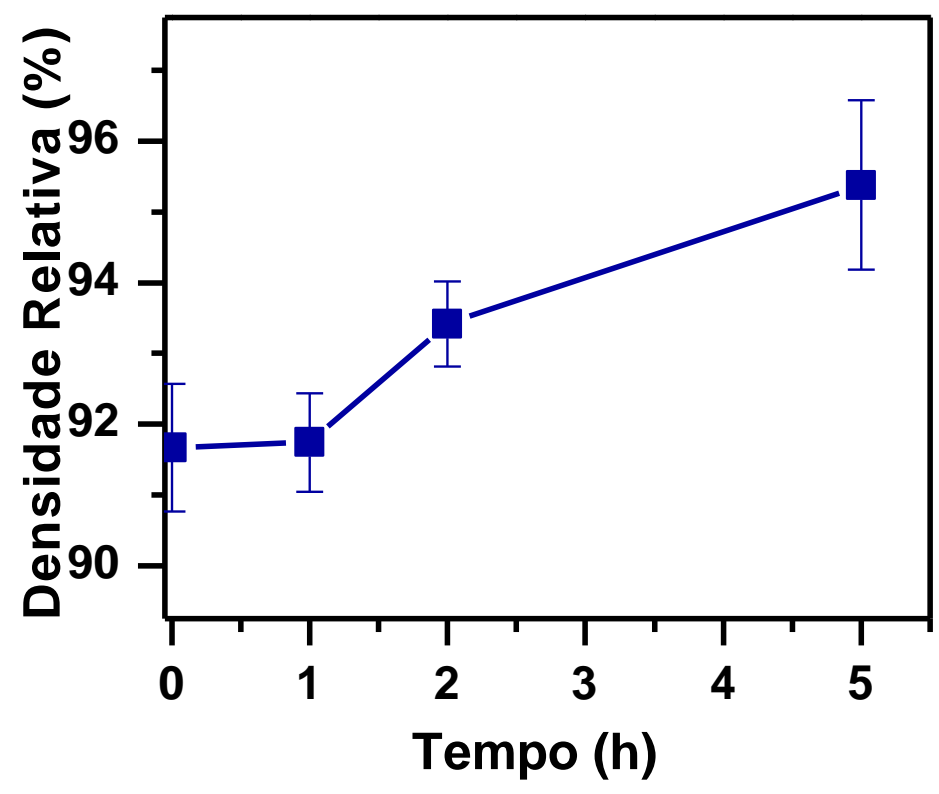

Figura 16: Densidade relativa em função do tempo para amostras SDC1 utilizando a sinterização em duas etapas tradicional, onde $T_{1}=1100{ }^{\circ} \mathrm{C} / 1 \mathrm{~h}$ e $T_{2}$ $=1450^{\circ} \mathrm{C}$ com diferentes $t_{2}$.

Nesse caso, para tempos até $1 \mathrm{~h}$ não ocorreu um aumento significativo na densidade relativa. Para tempos superiores a $1 \mathrm{~h}$ a densidade aumentou cerca de $3 \%$ até $t_{2}=5 \mathrm{~h}$.

Para o material obtido por mistura de óxidos não foi possível atingir densidades maiores que $90 \%$ da densidade teórica, como mostra a tabela VIII.

Tabela VIII - Condições de sinterização e densidade relativa para amostras obtidas por mistura de óxidos (SDC2).

\begin{tabular}{|c|c|}
\hline Condições de sinterização & Densidade relativa (\%) \\
\hline $1450^{\circ} \mathrm{C} / 0 \mathrm{~h}+1350^{\circ} \mathrm{C} / 10 \mathrm{~h}$ & $83,6 \pm 1,2$ \\
\hline $1450{ }^{\circ} \mathrm{C} / 0 \mathrm{~h}+1350 \stackrel{\circ}{\circ} \mathrm{C} / 24 \mathrm{~h}$ & $83,3 \pm 1,5$ \\
\hline $1450 \stackrel{\circ}{\circ} / 0 h+1400 \stackrel{\circ}{\circ} / 10 h$ & $86,9 \pm 1,4$ \\
\hline $1450^{\circ} \mathrm{C} / 0 \mathrm{~h}+1400{ }^{\circ} \mathrm{C} / 24 \mathrm{~h}$ & $89,5 \pm 1,2$ \\
\hline
\end{tabular}

Os resultados de dilatometria e densidade aparente mostraram que as amostras preparadas pela mistura dos óxidos atingiram menor densidade independente do processo de sinterização. Isto está provavelmente associado com o fato de, nestas amostras, parte da energia fornecida durante a sinterização ser gasta para formar a solução sólida, ou seja, há uma reação 
concorrente com a densificação. Além disso, o valor da área de superfície específica é inferior para este material.

A figura 17 mostra difratogramas de raios $X$ para as amostras preparadas com a solução sólida comercial e por mistura de óxidos após a sinterização em duas etapas e também em duas etapas tradicional.

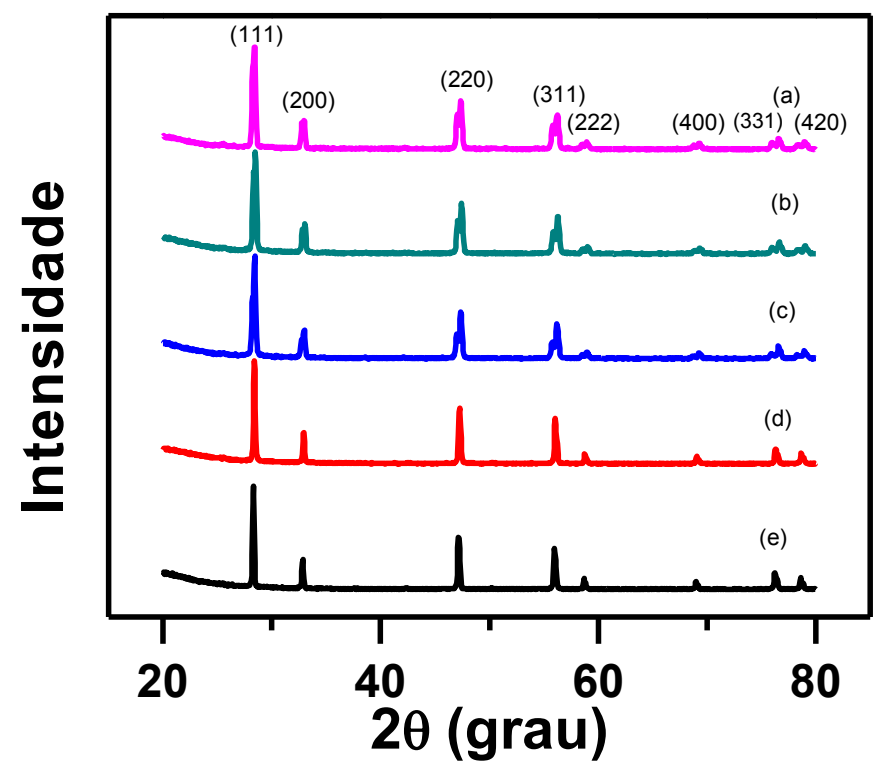

Figura 17: Difratogramas de raios $X$ das amostras SDC1 e SDC2 em diferentes temperaturas: (a) $1500{ }^{\circ} \mathrm{C} / 0 \mathrm{~h}$ (SDC2-TSS), (b) $1450{ }^{\circ} \mathrm{C} / 0 \mathrm{~h}-1300{ }^{\circ} \mathrm{C} / 5 \mathrm{~h}$ (SDC2-TSS), (c) $1450^{\circ} \mathrm{C} / 0 \mathrm{~h}$ (SDC2-TSS), (d) $1450^{\circ} \mathrm{C} / 0 \mathrm{~h}$ (SDC1-TSS) e

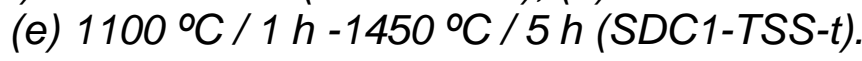

Nos difratogramas, os picos correspondem àqueles de óxido de cério com pequeno deslocamento angular devido à formação de solução sólida, ou seja, nas condições analisadas o samário já está em solução sólida. Não foram observados picos de difração espúrios. Os picos de difração são estreitos evidenciando a alta cristalinidade das amostras após a sinterização, independente do método empregado.

A observação de amostras por microscopia eletrônica de varredura permitiu determinar o tamanho médio de grãos para diferentes condições. As figuras 18 e 19 mostram a superfície de fratura de amostras SDC1 e SDC2 sinterizadas em duas etapas. 


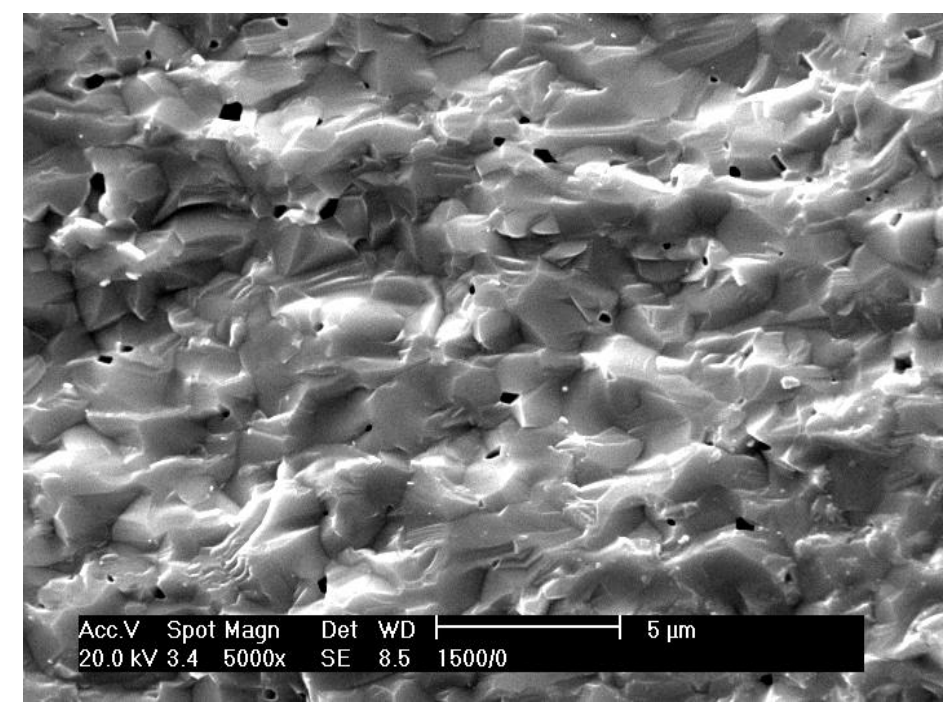

Figura 18: Micrografia obtida em microscópio eletrônico de varredura para amostra SDC1 fraturada e sinterizada em duas etapas (TSS) a $T_{1}=1500$ $\stackrel{\circ}{C} / 0 \mathrm{~h}$.

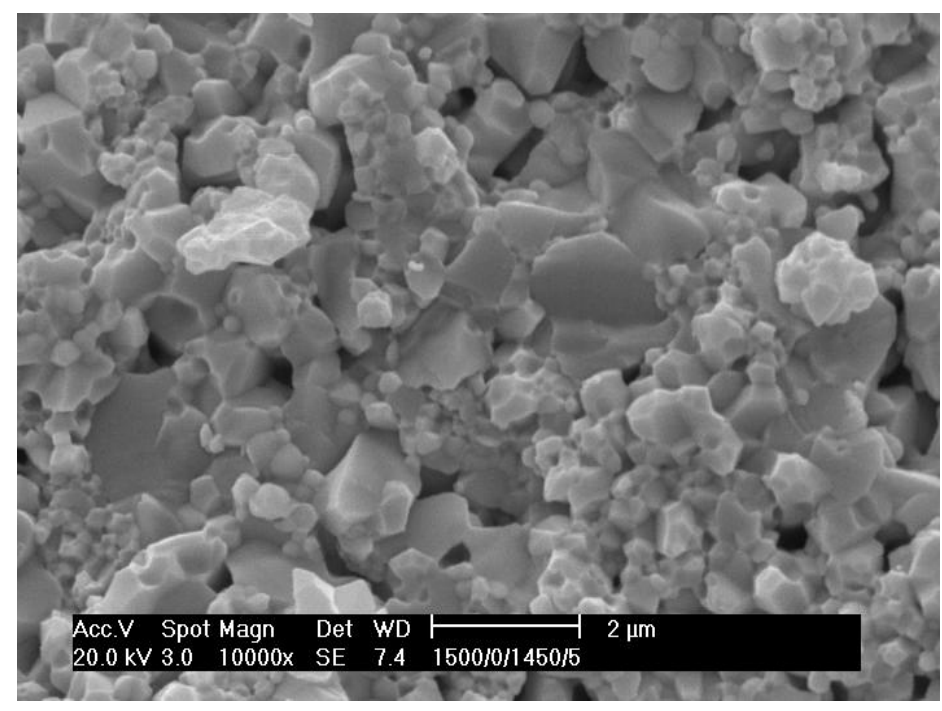

Figura 19: Micrografia obtida em microscópio eletrônico de varredura para amostra SDC2 fraturada e sinterizada em duas etapas (TSS) a $T_{1}=1500$ ${ }^{\circ} \mathrm{C} / 0 \mathrm{~h} / 1450{ }^{\circ} \mathrm{C} / 5 \mathrm{~h}$.

A microestrutura da céria-samária SDC1 é caracterizada por fratura mista preferencialmente transgranular, como mostrado na figura 18. A porosidade está distribuída aleatoriamente. Por outro lado, o modo de fratura da amostra SDC2 (figura 19) é preferencialmente intergranular evidenciando

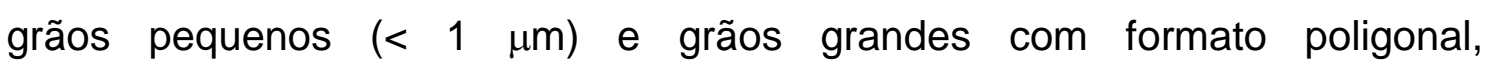
aleatoriamente distribuídos.

As figuras 20, 21 e 22 referem-se a amostras preparadas com a solução sólida comercial (SDC1). 
A figura 20 mostra micrografias obtidas para amostras sinterizadas pelo método em duas etapas (TSS) na temperatura $\mathrm{T}_{1}=1300 \stackrel{\circ}{\circ} \mathrm{C} / 0 \mathrm{~h}$ em temperaturas $\mathrm{T}_{2}=1250^{\circ} \mathrm{C}$ e $1275^{\circ} \mathrm{C}\left(\mathrm{t}_{2}=5 \mathrm{~h}\right)$.
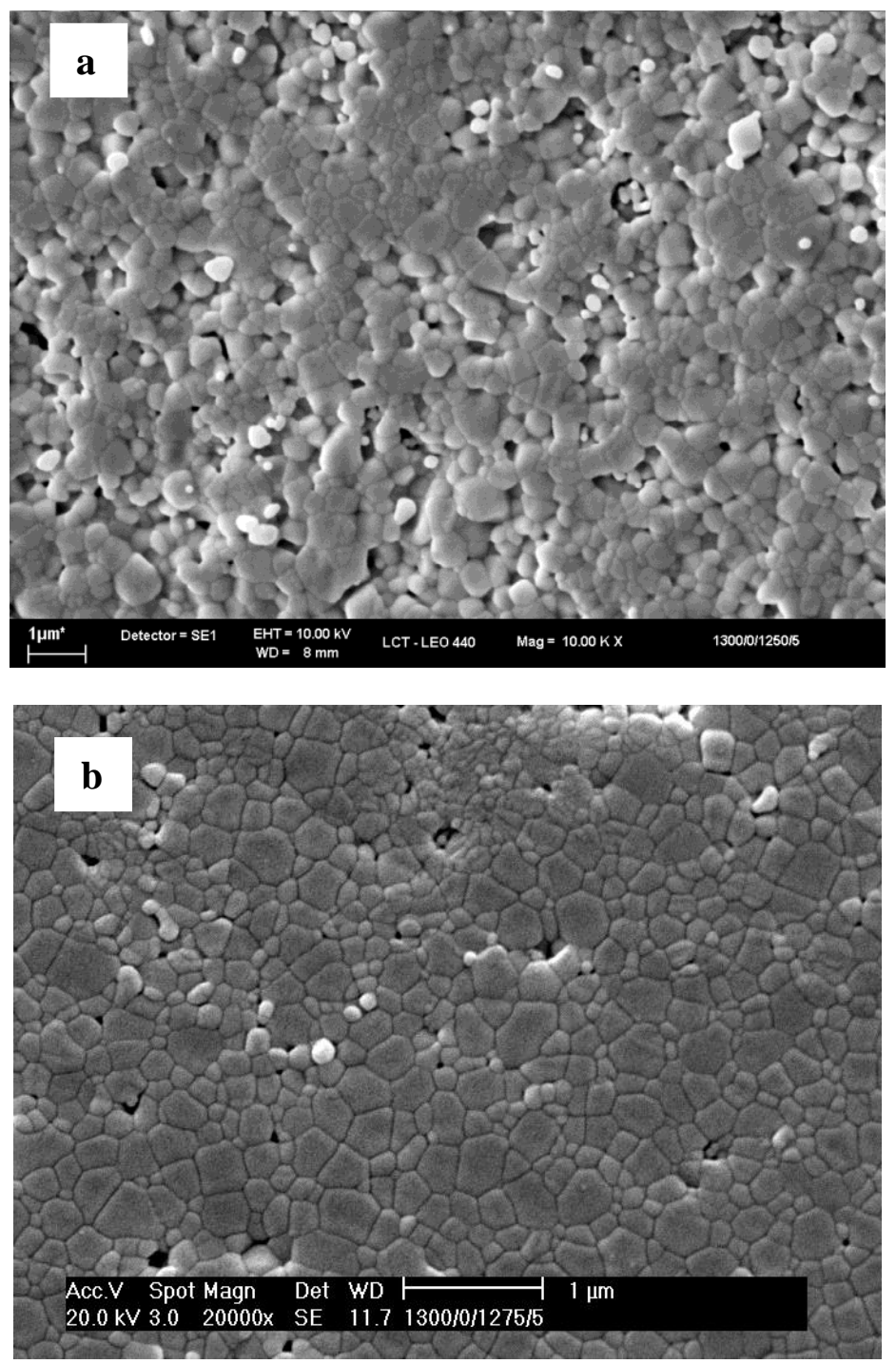

Figura 20: Micrografias obtidas em microscópio eletrônico de varredura de amostras SDC1 sinterizadas em duas etapas (TSS) na temperatura $T_{1}=$ $1300{ }^{\circ} \mathrm{C} / \mathrm{O} \mathrm{h}$ em diferentes temperaturas $T_{2}$ a) $1250{ }^{\circ} \mathrm{C}$ b) $1275{ }^{\circ} \mathrm{C}$, por tempo $t_{2}=5 h$.

Na temperatura $T_{2}=1250{ }^{\circ} \mathrm{C}$ é possível observar fração considerável de porosidade na amostra, e grãos submicrométricos. Com o aumento de $25 \stackrel{\circ}{ } \mathrm{C}$ na temperatura $T_{2}$, a porosidade diminui de forma substancial e ocorre crescimento dos grãos, mas o tamanho médio ainda é submicrométrico.

A figura 21 mostra micrografias obtidas para amostras sinterizadas pelo processo TSS na temperatura $T_{1}=1450 \stackrel{\circ}{\circ} \mathrm{C} / 0 \mathrm{~h}$ em temperaturas $T_{2}=1350 \stackrel{\circ}{\circ}$ (a) e $1400 \stackrel{\circ}{\circ}$ (b). 

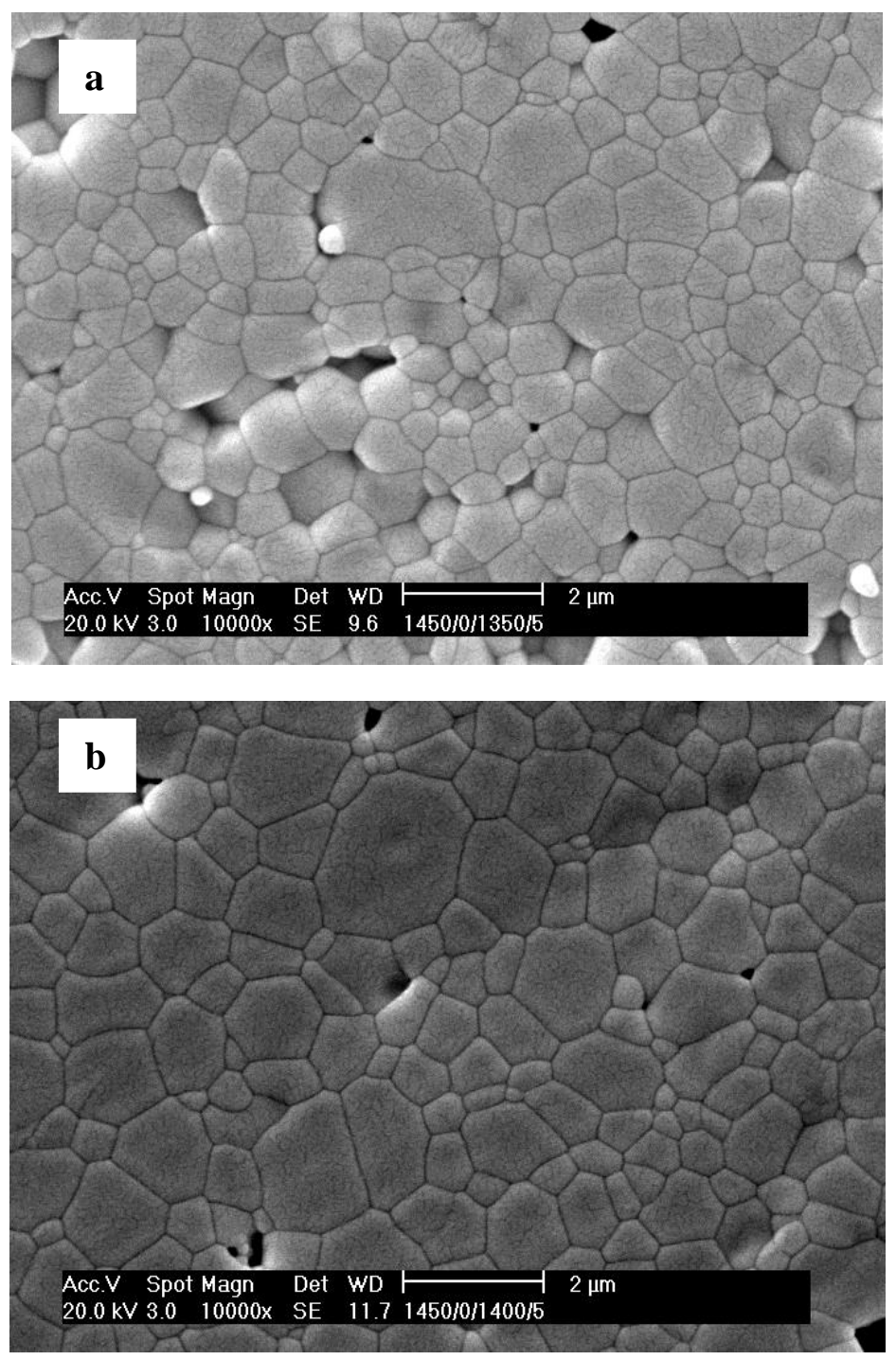

Figura 21: Micrografias obtidas em microscópio eletrônico de varredura de amostras SDC1 sinterizadas pelo processo TSS na temperatura $T_{1}=1450^{\circ} \mathrm{C} /$ $0 \mathrm{~h}$ em diferentes temperaturas $T_{2}$ : a) $1350^{\circ} \mathrm{C}$ e b) $1400^{\circ} \mathrm{C}$ e $t_{2}=5 \mathrm{~h}$.

Para $\mathrm{T}_{2}=1350^{\circ} \mathrm{C}$ e $1400^{\circ} \mathrm{C}$ há ainda porosidade residual. Para um aumento de $50 \stackrel{\circ}{ } \mathrm{C}$ na temperatura $\mathrm{T}_{2} \mathrm{o}$ aspecto mais relevante é o aumento do tamanho dos grãos.

Para comparar o aumento no tamanho médio de grãos das amostras sinterizadas em duas etapas (TSS) e em duas etapas tradicional (TSS-t), também foram feitas observações por microscopia eletrônica de varredura destas últimas amostras. A figura 22 mostra micrografias obtidas para amostras sinterizadas pelo processo TSS-t na temperatura $T_{1}=1100^{\circ} \mathrm{C} / 1 \mathrm{~h}$ e $T_{2}=1450$ ${ }^{\circ} \mathrm{C}$ em diferentes tempos de patamar $\mathrm{t}_{2}$. 

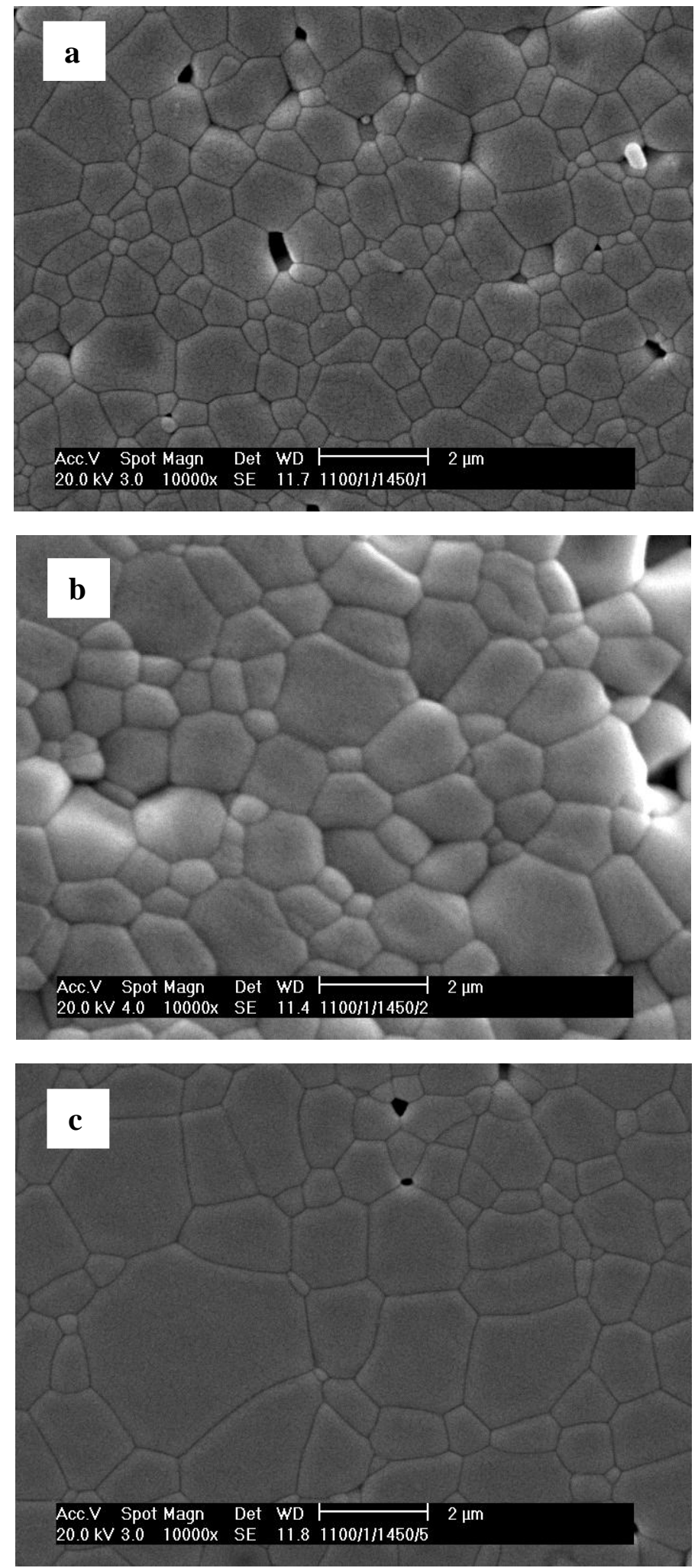

Figura 22: Micrografias obtidas em microscópio eletrônico de varredura de amostras SDC1 sinterizadas pelo processo em duas etapas tradicional (TSS-t) na temperatura $T_{1}=1100^{\circ} \mathrm{C} / 1 \mathrm{~h}$ e $T_{2}=1450 \circ \mathrm{C}$ em diferentes tempos t2: a) $1 h, b) 2 h$, e c) $5 h$. 
Para $t_{2}=1 \mathrm{~h}$ observam-se grãos micrométricos e existe porosidade que diminui com $\mathrm{o}$ aumento de $\mathrm{t}_{2}$ para $2 \mathrm{~h}$ tornado-se praticamente desprezível para $\mathrm{t}_{2}=5 \mathrm{~h}$. Com o aumento de $\mathrm{t}_{2}$ ocorreu um crescimento no tamanho médio de grãos que foi superior àqueles obtidos para as amostras sinterizadas em duas etapas (TSS), como esperado.

As amostras sinterizadas em duas etapas (TSS) e sinterizadas em duas etapas tradicional (TSS-t) apresentaram porosidade preferencialmente localizada ao longo dos contornos de grão ou nas junções triplas. Então, em princípio, ainda é possível obter amostras mais densas.

A figura 23 mostra uma micrografia obtida para amostra sinterizada pelo processo de sinterização em duas etapas (TSS) para a solução sólida obtida por mistura de óxidos (SDC2) na temperatura $\mathrm{T}_{1}=1450 \stackrel{\circ}{\circ} \mathrm{C} / 0 \mathrm{~h} \mathrm{e} \mathrm{T}_{2}=1350 \stackrel{\circ}{\circ} \mathrm{C}$ / $24 \mathrm{~h}$.

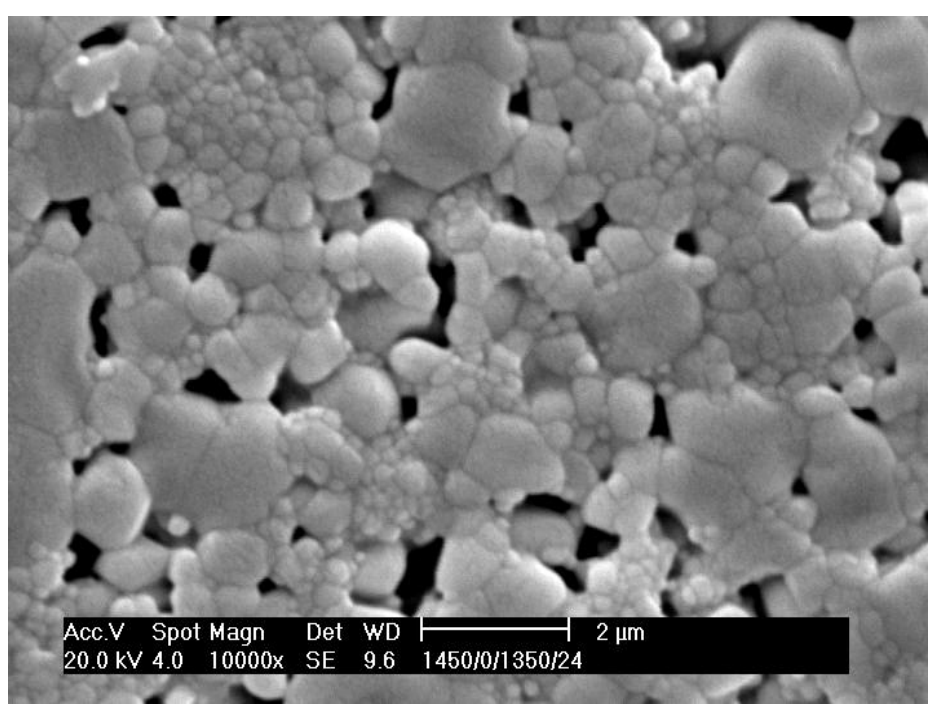

Figura 23: Micrografia obtida em microscópio eletrônico de varredura de amostra SDC2 sinterizada em duas etapas na temperatura $T_{1}=1450{ }^{\circ} \mathrm{C} / 0 \mathrm{~h}$ e $T_{2}=1350^{\circ} \mathrm{C} / 24 \mathrm{~h}$.

Neste caso, observa-se uma fração elevada de porosidade, e os grãos apresentam tamanhos muito distintos sugerindo uma distribuição bimodal. Não foram feitas medidas de tamanho médio de grãos neste tipo de amostra devido à alta porosidade, e à existência de grãos muito pequenos e difíceis de serem avaliados com precisão.

As figuras 24,25 e 26 exemplificam os tipos de histogramas obtidos na análise da distribuição de tamanho de grãos. 


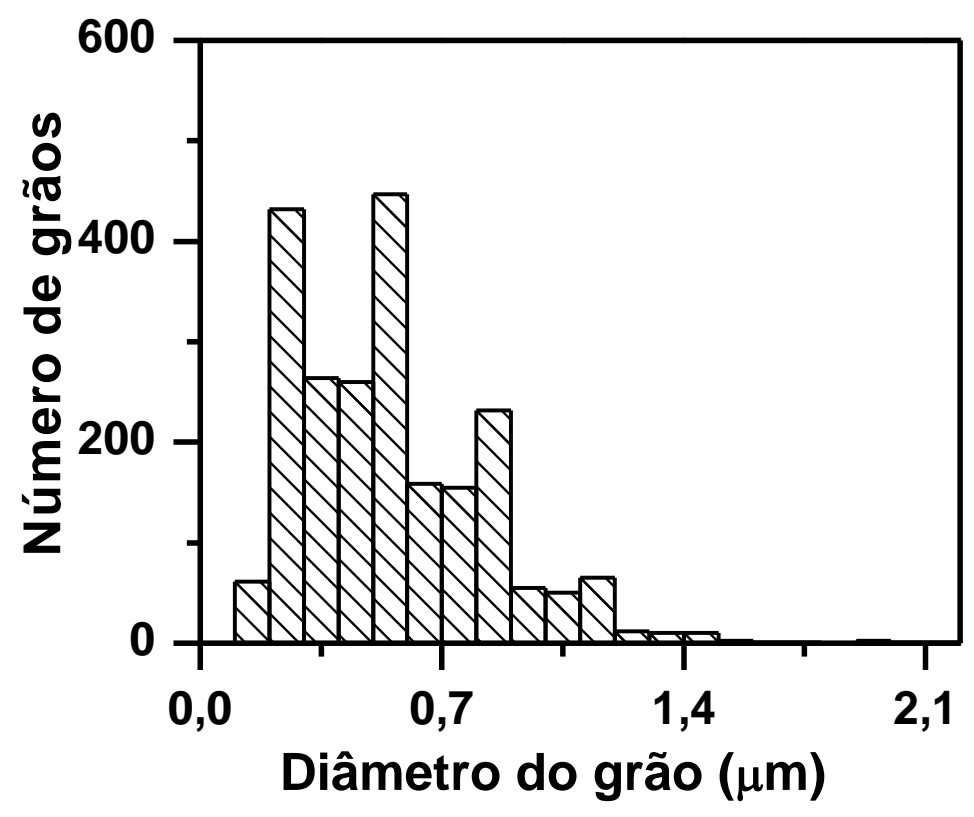

Figura 24: Histograma da distribuição de tamanho de grãos para amostras (SDC1) sinterizadas em duas etapas (TSS) com $T_{1}=1300^{\circ} \mathrm{C} / 0$ h e $T_{2}=1275$ ${ }^{\circ} \mathrm{C} / 5 \mathrm{~h}$.

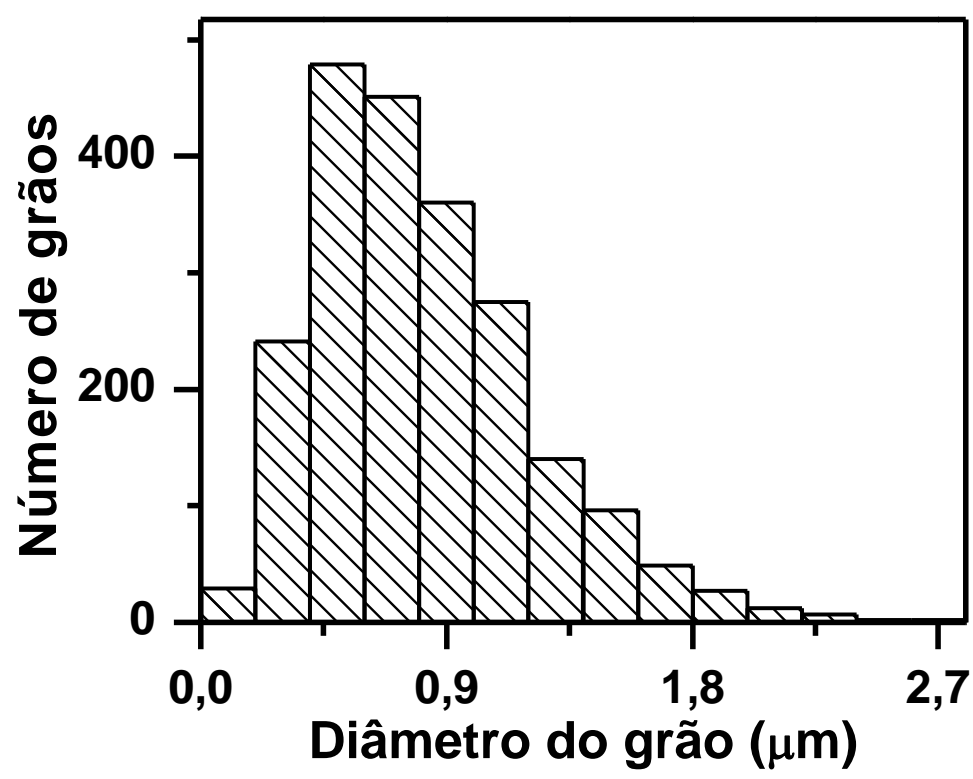

Figura 25: Histograma da distribuição de tamanho de grãos para amostras (SDC1) sinterizadas em duas etapas (TSS) com $T_{1}=1450^{\circ} \mathrm{C} / 0$ h e $T_{2}=1300$ ${ }^{\circ} \mathrm{C} / 5 \mathrm{~h}$. 


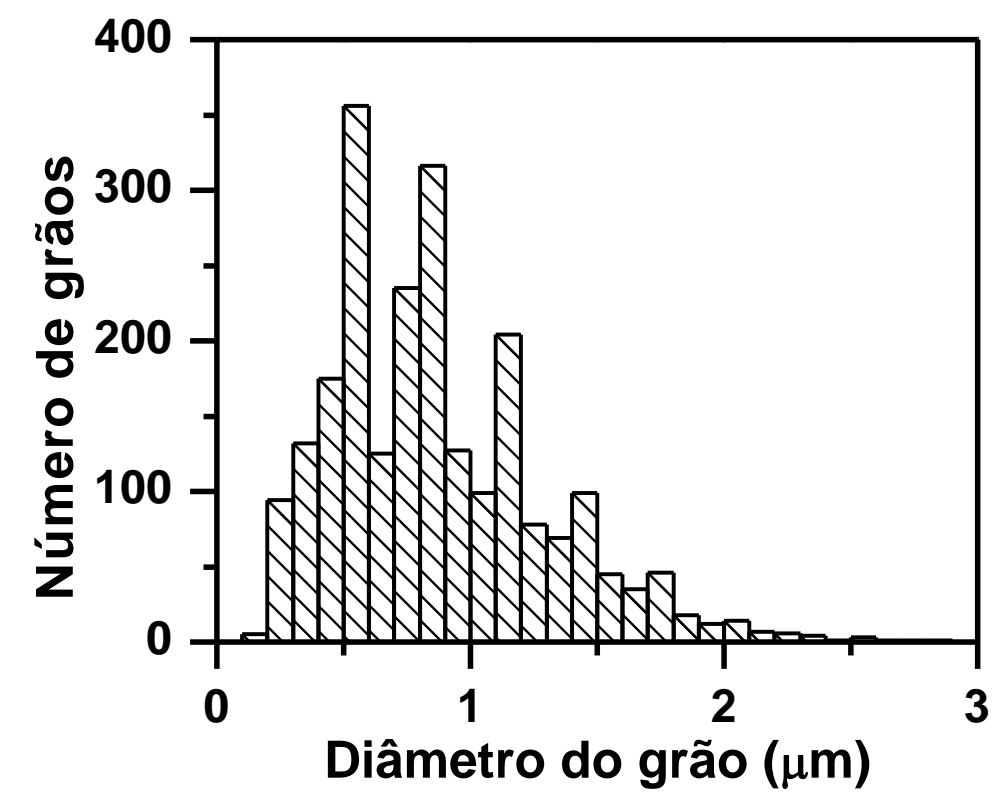

Figura 26: Histograma da distribuição de tamanho de grãos para amostras (SDC1) sinterizadas em duas etapas (TSS-t) $\operatorname{com} T_{1}=1100^{\circ} \mathrm{C} / 1 \mathrm{~h}$ e $T_{2}=1450$ ${ }^{\circ} \mathrm{C} / 1 \mathrm{~h}$.

Na tabela IX são listados os valores de tamanho médio de grãos determinados pelo método de Mendelson, utilizando a equação (10) [61] para diferentes amostras, onde DV é o desvio padrão e mede a dispersão no tamanho médio de grãos. 
Tabela IX: Tamanho médio de grão para as amostras (SDC1) sinterizadas em duas etapas com $T_{1}=1300 \stackrel{\circ}{\circ}$ e $T_{1}=1450 \stackrel{\circ}{\circ}$ em diferentes temperaturas $T_{2} \mathrm{e}$ $\mathrm{t}_{2} \mathrm{e}$ amostras sinterizadas em duas etapas tradicional com $\mathrm{T}_{1}=1100^{\circ} \mathrm{C} / 1 \mathrm{~h} \mathrm{e}$ $\mathrm{T}_{2}=1450 \stackrel{\circ}{\mathrm{C}}$ em diferentes tempos $\mathrm{t}_{2}$. $\mathrm{DV}=$ dispersão no valor de tamanho médio.

\begin{tabular}{ccc}
\hline $\begin{array}{c}\text { Condições de } \\
\text { sinterização } \\
\text { oc/h }\end{array}$ & Tamanho médio de grão $(\mu \mathrm{m})$ & DV \\
\hline $1300 / 0+1250 / 5$ & 0,54 & 0,23 \\
$1300 / 0+1250 / 10$ & 0,58 & 0,27 \\
$1300 / 0+1275 / 5$ & 0,58 & 0,27 \\
$1300 / 0+1275 / 10$ & 0,67 & 0,34 \\
$1450 / 0$ & 0,85 & 0,41 \\
$1450 / 0+1300 / 5$ & 0,85 & 0,39 \\
$1450 / 0+1350 / 5$ & 0,95 & 0,53 \\
$1450 / 0+1400 / 5$ & 1,30 & 0,67 \\
$1450 / 0+1425 / 5$ & 1,51 & 0,7 \\
$1100 / 1+1450 / 0$ & 0,88 & 0,46 \\
$1100 / 1+1450 / 1$ & 1,13 & 0,56 \\
$1100 / 1+1450 / 2$ & 1,48 & 0,89 \\
$1100 / 1+1450 / 5$ & 1,78 & 0,93 \\
$1200 / 1+1450 / 5$ & 1,72 & 0,88 \\
\hline
\end{tabular}

Observa-se que para $T_{1}=1300{ }^{\circ} \mathrm{C}$, não há aumento considerável no tamanho médio de grãos no patamar $T_{2}$. Quando $T_{1}=1450 \stackrel{\circ}{\mathrm{C}} \circ$ tamanho médio de grãos é similar àquele obtido após o patamar com $\mathrm{T}_{2}=1300^{\circ} \mathrm{C} / 5 \mathrm{~h}$. Isto sugere, que não há crescimento de grãos no patamar $\mathrm{T}_{2}$. Entretanto, para $\mathrm{T}_{2}$ maior que $1300{ }^{\circ} \mathrm{C}$, ocorre aumento no tamanho médio de grãos. Estes resultados mostram a importância da temperatura de pico no crescimento de grãos da céria-samária, e da temperatura $T_{2}$ no crescimento de grãos no segundo estágio de sinterização. No caso da sinterização em duas etapas tradicional, ocorre aumento no tamanho médio de grãos com o aumento do tempo do segundo patamar, como esperado.

Os resultados de microestrutura mostraram que apesar do método de sinterização em duas etapas, utilizado neste trabalho, não ter resultado em aumento da densificação da céria-samária, quando comparado com o método tradicional, houve redução significativa no tamanho médio de grãos.

As figuras 27 e 28 mostram a variação do tamanho médio de grãos em função do tempo de sinterização e em função da densidade relativa, 
respectivamente, para amostras sinterizadas em duas etapas (TSS) e sinterizadas em duas etapas tradicional (TSS-t).

Na figura 28 os números acima dos pontos correspondem aos tempos do segundo patamar nas sinterizações.

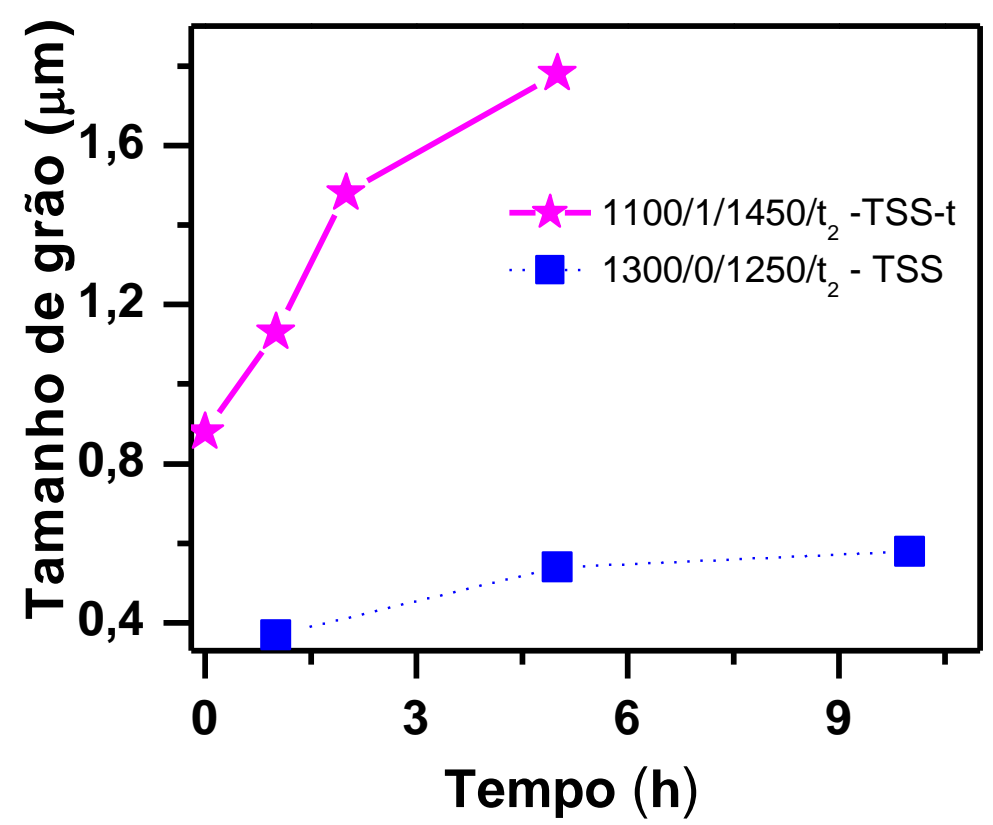

Figura 27: Variação do tamanho médio de grãos para amostras sinterizadas em duas etapas (TSS) $1300^{\circ} \mathrm{C} / 0 \mathrm{~h} / 1250^{\circ} \mathrm{C}$ e sinterizadas em duas etapas tradicional (TSS-t) - $1100{ }^{\circ} \mathrm{C} / 1 \mathrm{~h} / 1450{ }^{\circ} \mathrm{C}$ em função do $t_{2}$.

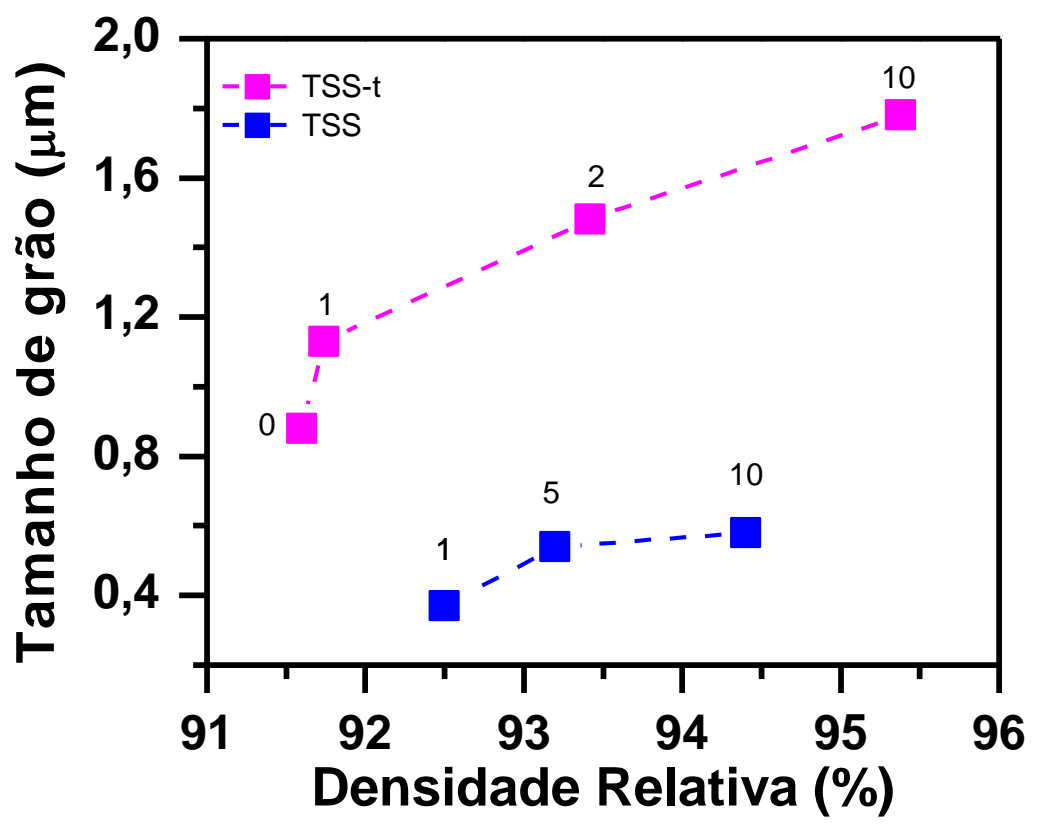

Figura 28: Variação do tamanho médio de grãos para as amostras sinterizadas em duas etapas (TSS) $1300^{\circ} \mathrm{C} / 0 \mathrm{~h} / 1250^{\circ} \mathrm{C} / \mathrm{t}_{2}$ e sinterizadas em duas etapas tradicional (TSS-t) $1100^{\circ} \mathrm{C} / 1 \mathrm{~h} / 1450{ }^{\circ} \mathrm{C} / \mathrm{t}_{2}$ em função da densidade relativa. 
O crescimento de grãos é acelerado nas amostras sinterizadas pelo processo tradicional com densidade superior a $91 \% \mathrm{DT}$, enquanto que 0 método não tradicional proporciona um crescimento comparativamente lento, para densidades superiores a $92 \%$ DT.

Por fim, serão mostrados e discutidos os principais resultados de medidas da condutividade elétrica de amostras selecionadas. As figuras 29, 30 e 31 mostram diagramas de impedância típicos. Nesses diagramas é plotada a parte imaginária em função da parte real da impedância medida, normalizadas pelas dimensões das amostras. Os números nos diagramas indicam 0 logaritmo decimal da frequência (em $\mathrm{Hz})$.

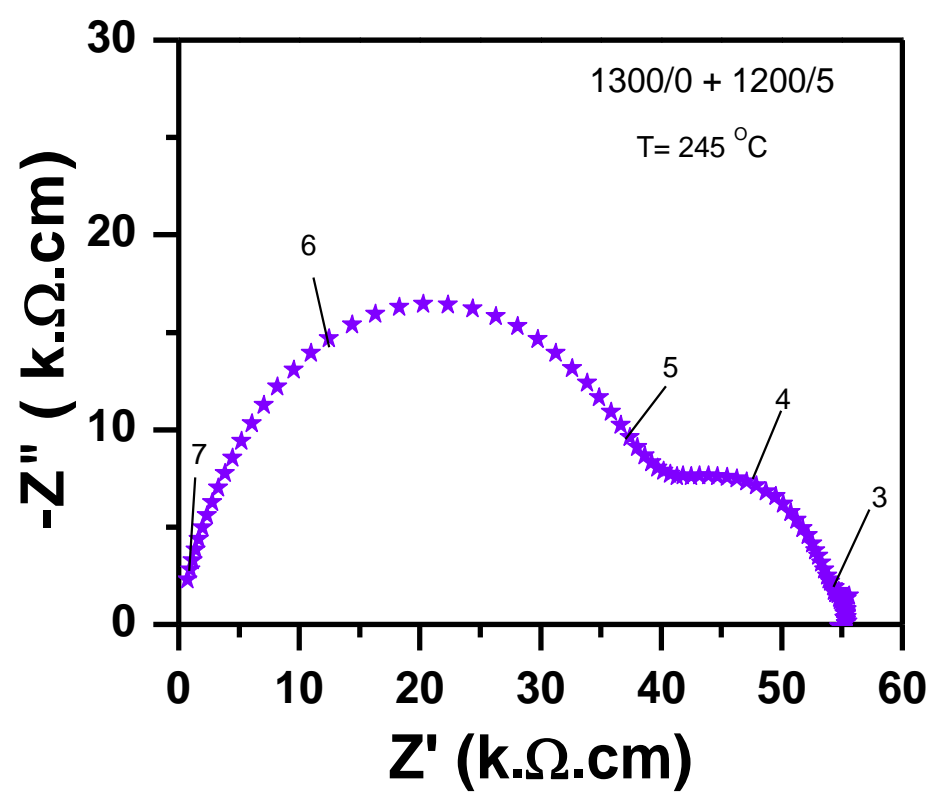

Figura 29: Diagrama de impedância da amostra sinterizada em duas etapas na temperatura $T_{1}=1300{ }^{\circ} \mathrm{C} / 0 \mathrm{~h}$ e $T_{2}=1200{ }^{\circ} \mathrm{C} / 5 \mathrm{~h}$.

Temperatura de medida $245 \stackrel{\circ}{\circ}$. 


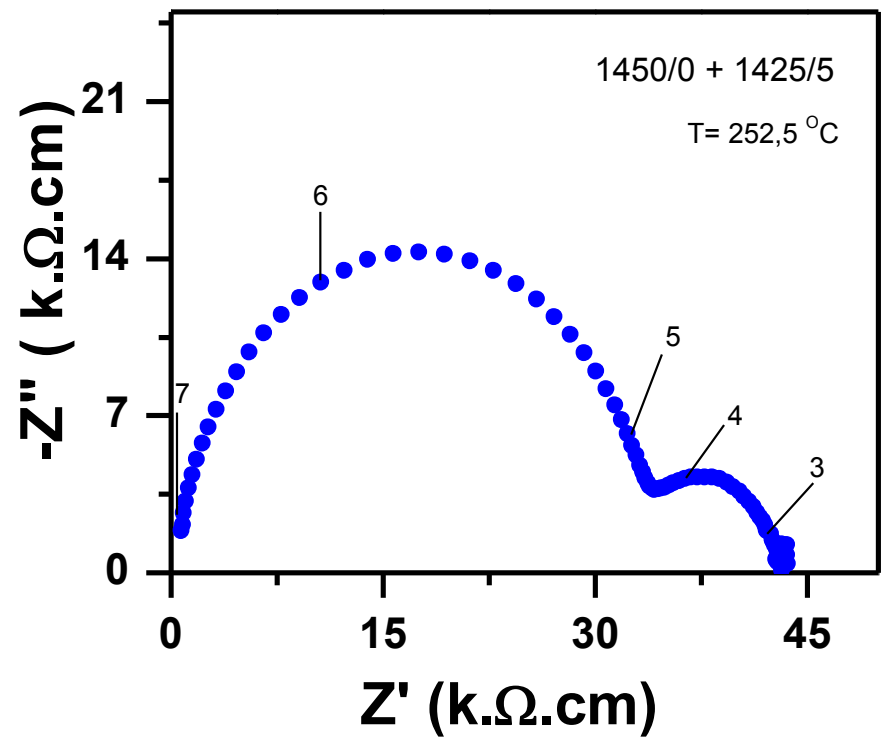

Figura 30: Diagrama de impedância da amostra sinterizada em duas etapas na temperatura $T_{1}=1450^{\circ} \mathrm{C} / 0 \mathrm{~h}$ e $T_{2}=1425^{\circ} \mathrm{C} / 5 \mathrm{~h}$.

Temperatura de medida $252,5^{\circ} \mathrm{C}$.

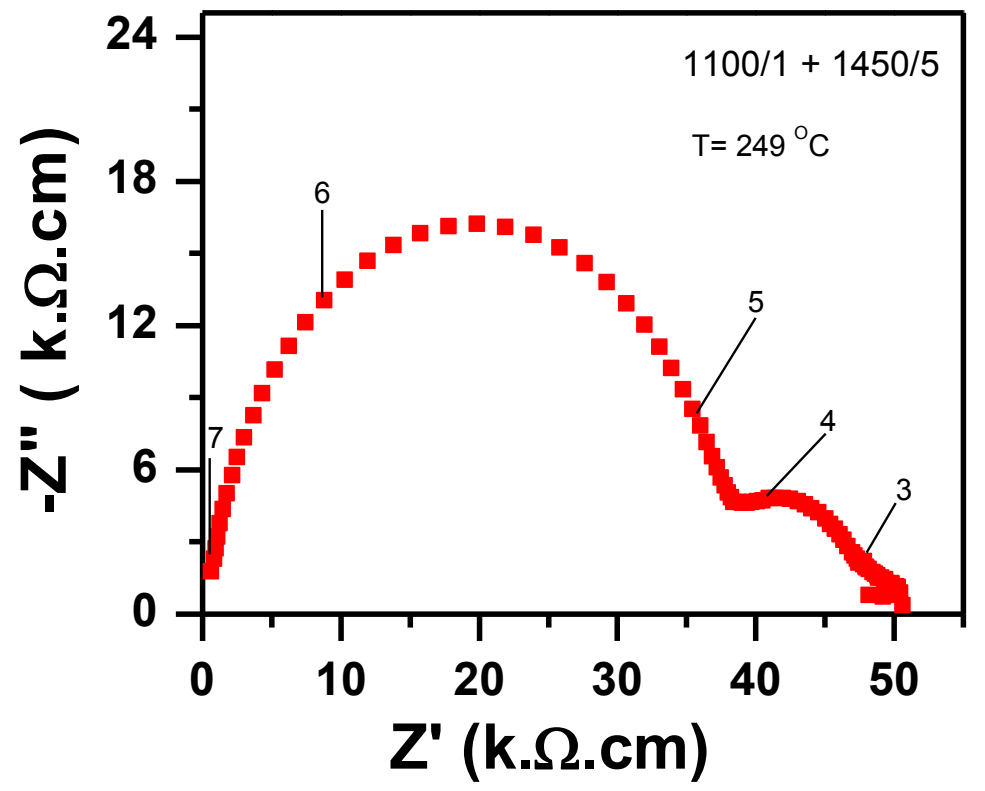

Figura 31: Diagrama de impedância da amostra sinterizada em duas etapas tradicional na temperatura $T_{1}=1100^{\circ} \mathrm{C} / 1 \mathrm{~h}$ e $T_{2}=1450^{\circ} \mathrm{C} / 5 \mathrm{~h}$. Temperatura de medida $249{ }^{\circ} \mathrm{C}$.

Todos os diagramas de impedância apresentaram forma característica consistido de dois semicírculos, que são atribuídos à resistividade dos grãos (mais alta frequência) e ao bloqueio exercido aos portadores de carga pelos contornos de grão (menor frequência).

Amostras sinterizadas pelos processos TSS e TSS-t foram analisadas por espectroscopia de impedância para a determinação da condutividade em 
função da temperatura. Os valores da condutividade foram calculados e plotados em função do inverso da temperatura.

As amostras utilizadas nas caracterizações elétricas foram preparadas com a solução sólida comercial (SDC1) por possuírem maior densificação.

As figuras 32 e 33 mostram o comportamento da condutividade dos grãos para amostras sinterizadas em duas etapas com $\mathrm{T}_{1}=1300 \stackrel{\circ}{\circ} \mathrm{C} / 0 \mathrm{~h} \mathrm{e} \mathrm{T}_{1}=$ $1450 \stackrel{\circ}{\circ} \mathrm{C} / 0 \mathrm{~h}$ com diferentes $\mathrm{T}_{2}$, e $\mathrm{t}_{2}=5 \mathrm{~h}$ e $10 \mathrm{~h}$.

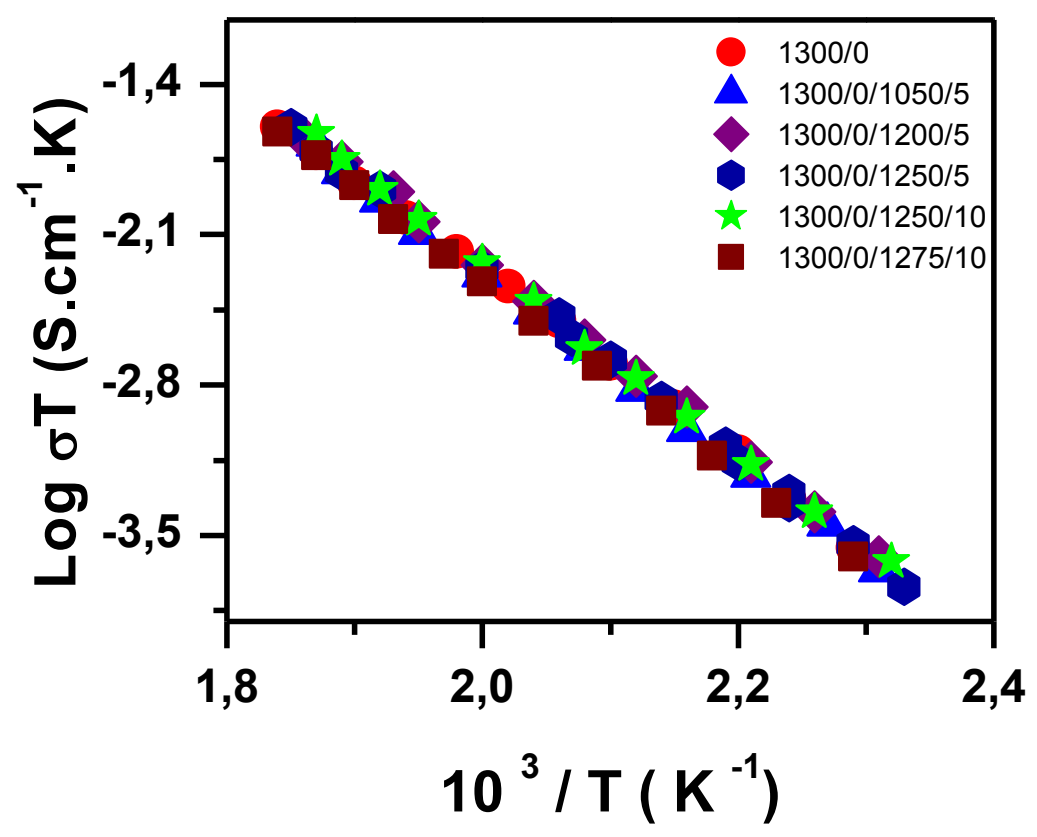

Figura 32: Gráficos de Arrhenius da condutividade elétrica dos grãos das amostras sinterizadas em duas etapas (TSS) para $T_{1}=1300{ }^{\circ} \mathrm{C} / 0 \mathrm{~h} \mathrm{em}$ diferentes temperaturas $T_{2}$ e $t_{2}=5$ e $10 \mathrm{~h}$. 


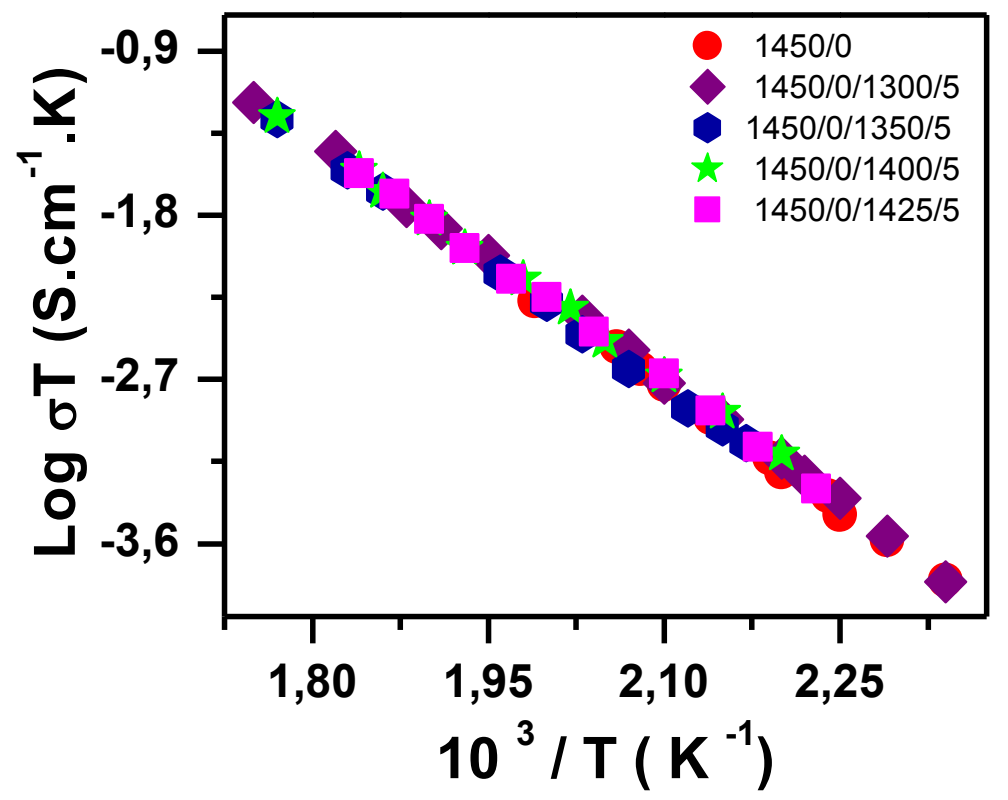

Figura 33: Gráficos de Arrhenius da condutividade elétrica dos grãos das amostras sinterizadas em duas etapas (TSS) para $T_{1}=1450{ }^{\circ} \mathrm{C} / 0 \mathrm{~h}$ em diferentes temperaturas $T_{2}$ e $t_{2}=5 \mathrm{~h}$.

Verifica-se que as amostras apresentam um comportamento típico de Arrhenius, com a variação linear do logaritmo da condutividade em função do inverso da temperatura obtida pela equação (13).

Observa-se que não há variação da condutividade dos grãos com o perfil de sinterização. Este resultado já era esperado, pois, na ausência de variações composicionais, a condutividade intragranular deve permanecer constante.

As figuras 34 e 35 mostram o comportamento da condutividade dos contornos de grão para amostras sinterizadas em duas etapas com $T_{1}=1300$ $\stackrel{\circ}{ } \mathrm{C} / 0 \mathrm{~h} \mathrm{e} \mathrm{T}_{1}=1450^{\circ} \mathrm{C} / 0 \mathrm{~h}$ com diferentes $\mathrm{T}_{2}$ e $\mathrm{t}_{2}=5 \mathrm{~h}$ e $10 \mathrm{~h}$. 


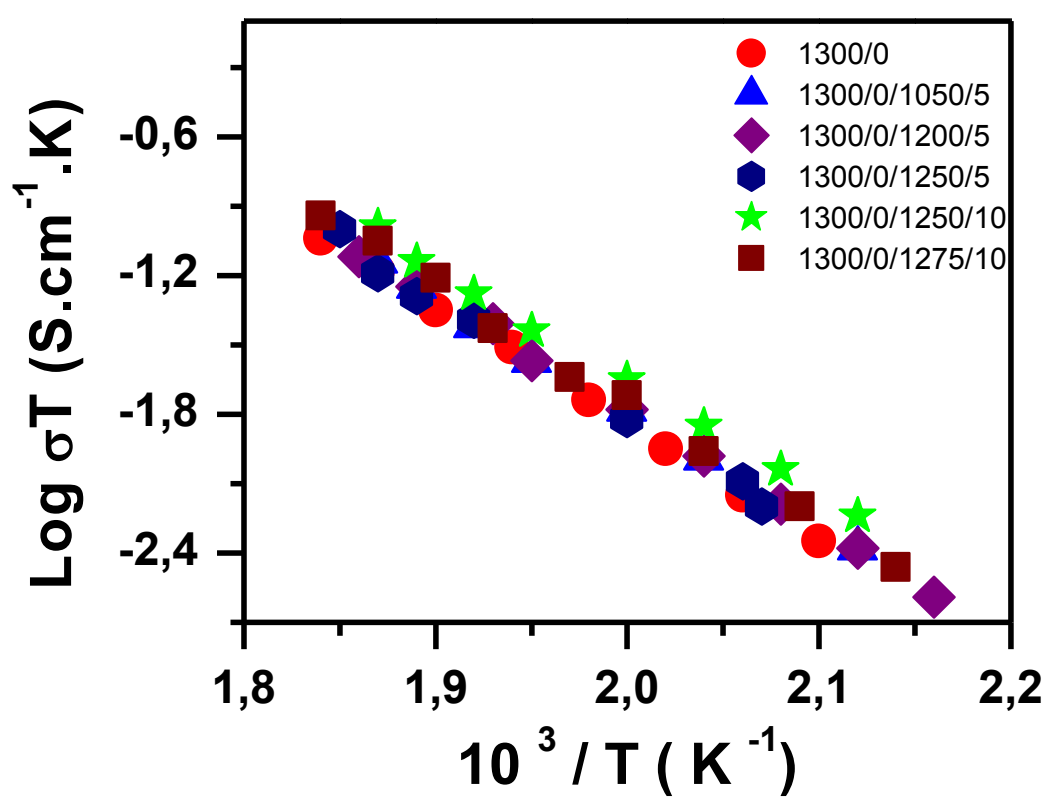

Figura 34: Gráficos de Arrhenius da condutividade elétrica dos contornos de grão das amostras sinterizadas em duas etapas (TSS) para $T_{1}=1300{ }^{\circ} \mathrm{C} / 0 \mathrm{~h}$ em diferentes temperaturas $T_{2}$ e $t_{2}=5 \mathrm{~h}$ e $10 \mathrm{~h}$.

Para $T_{1}=1300 \stackrel{\circ}{ } \mathrm{C}$ (figura 34 ) observa-se que a condutividade dos contornos de grão praticamente independe de $T_{2}$ e de $t_{2}$. É importante salientar que não foi observada variação significativa no tamanho médio de grãos (dentro do erro experimental). Quando há aumento no tamanho dos grãos, ou seja, diminuição na área total ocupada pelos contornos de grão, diminui a resistência do contorno de grão e, com isso, aumenta a condutividade do contorno de grão. Isto acontece, pois os contornos de grão oferecem resistência à migração dos portadores de carga iônicos, isto é, atuam como uma barreira adicional para a difusão. 


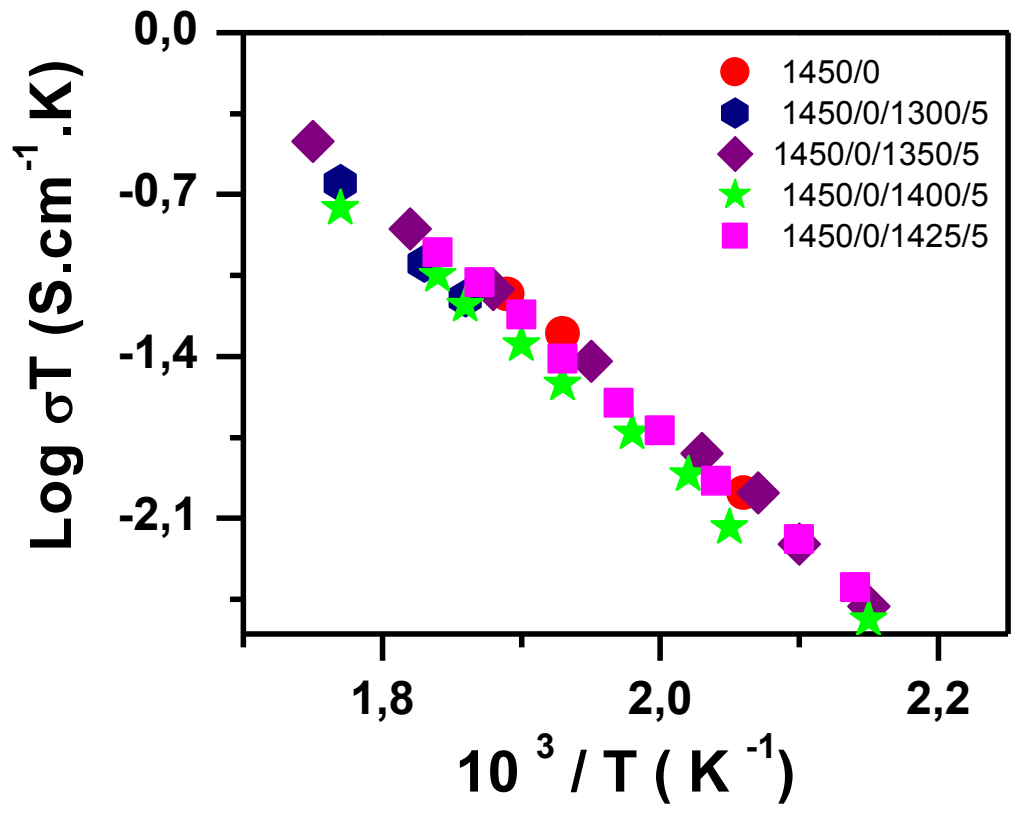

Figura 35: Gráficos de Arrhenius da condutividade elétrica dos contornos de grão das amostras sinterizadas em duas etapas (TSS) para $T_{1}=1450{ }^{\circ} \mathrm{C} / 0 \mathrm{~h}$ em diferentes temperaturas $T_{2}$.

Os resultados obtidos para a condutividade dos contornos de grão, com $T_{1}=1450 \stackrel{\circ}{\circ}$ (figura 35) são similares àqueles obtidos para $T_{1}=1300{ }^{\circ} \mathrm{C}$ (figura 34). As pequenas variações observadas nesses gráficos estão dentro do erro experimental de análise dos dados.

As figuras 36 e 37 mostram, respectivamente, o comportamento da condutividade dos grãos e dos contornos de grão para amostras SDC1 sinterizadas pelo processo em duas etapas tradicional, com diferentes $T_{1}$ e $t_{1}=$ $1 \mathrm{~h} \mathrm{e} \mathrm{T}_{2}=1450 \stackrel{\circ}{\circ} \mathrm{C} / 5 \mathrm{~h}$. 


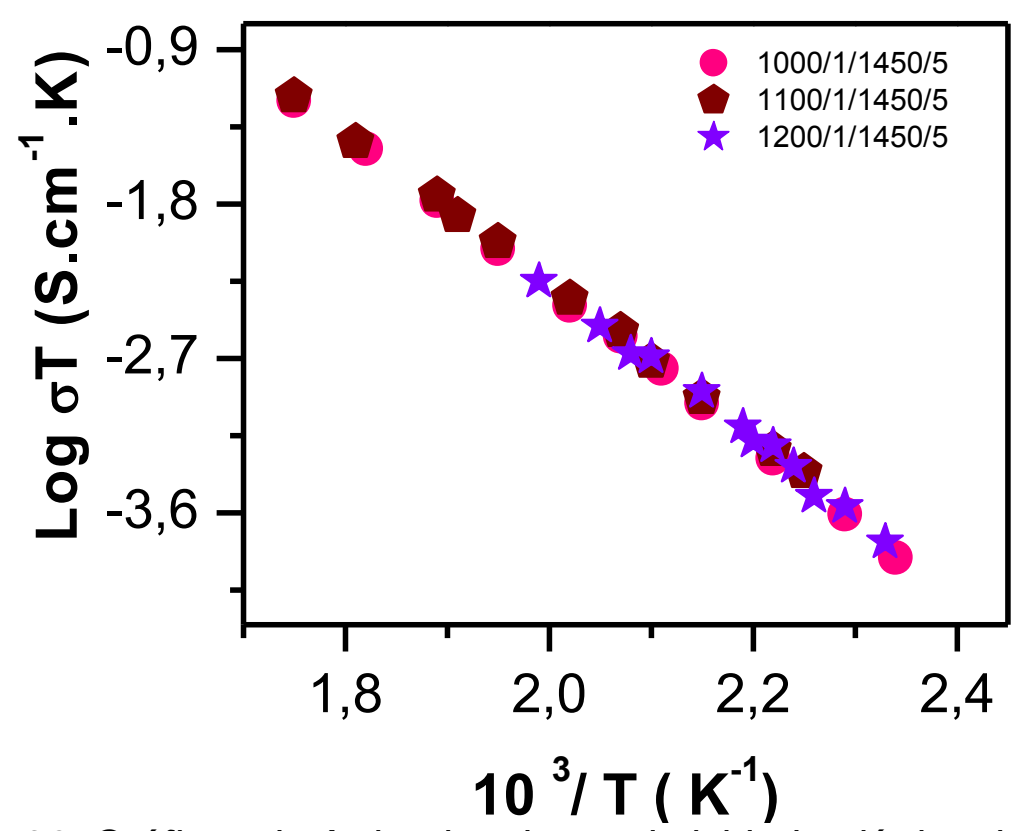

Figura 36: Gráficos de Arrhenius da condutividade elétrica dos grãos das amostras sinterizadas em duas etapas tradicional (TSS-t) para diferentes $T_{1}$ e $t_{1}=1 \mathrm{~h}$ e $T_{2}=1450{ }^{\circ} \mathrm{C} / 5 \mathrm{~h}$.

Não há variação da condutividade dos grãos com a temperatura de sinterização, como esperado, de forma similar ao obtido para amostras sinterizadas pelo processo em duas etapas (figuras 32 e 33 ).

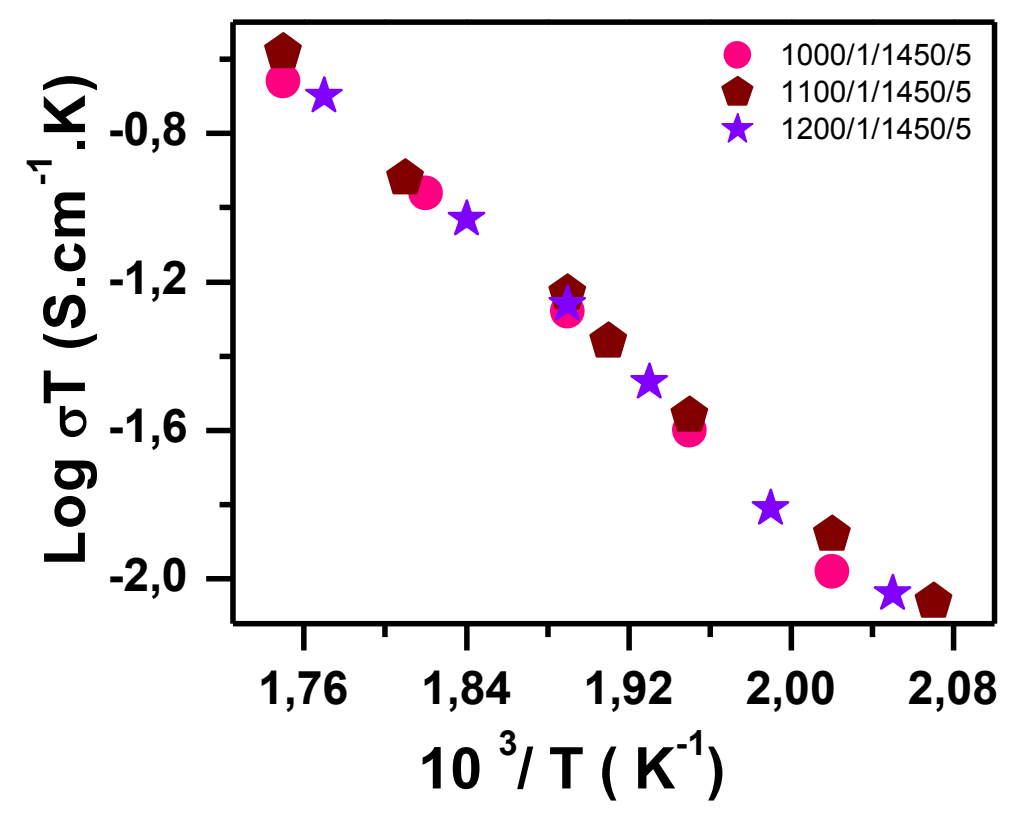

Figura 37: Gráficos de Arrhenius da condutividade elétrica dos contornos de grão das amostras sinterizadas em duas etapas tradicional (TSS-t) para diferentes $T_{1}$ e $t_{1}=1 \mathrm{~h}$ e $T_{2}=1450{ }^{\circ} \mathrm{C} / 5 \mathrm{~h}$.

Para as amostras sinterizadas pelo método de duas etapas tradicional (TSS-t), a condutividade dos contornos de grão também não variou com o 
aumento de $T_{1}$. Isto mostra que nestas temperaturas a variação no tamanho médio de grãos não é suficiente para causar mudanças na condutividade elétrica dos contornos de grão.

As figuras 38 e 39 mostram, respectivamente, o comportamento da condutividade dos grãos e dos contornos de grão para amostras sinterizadas pelos métodos de duas etapas (TSS) e duas etapas tradicional (TSS-t), para fins comparativos.

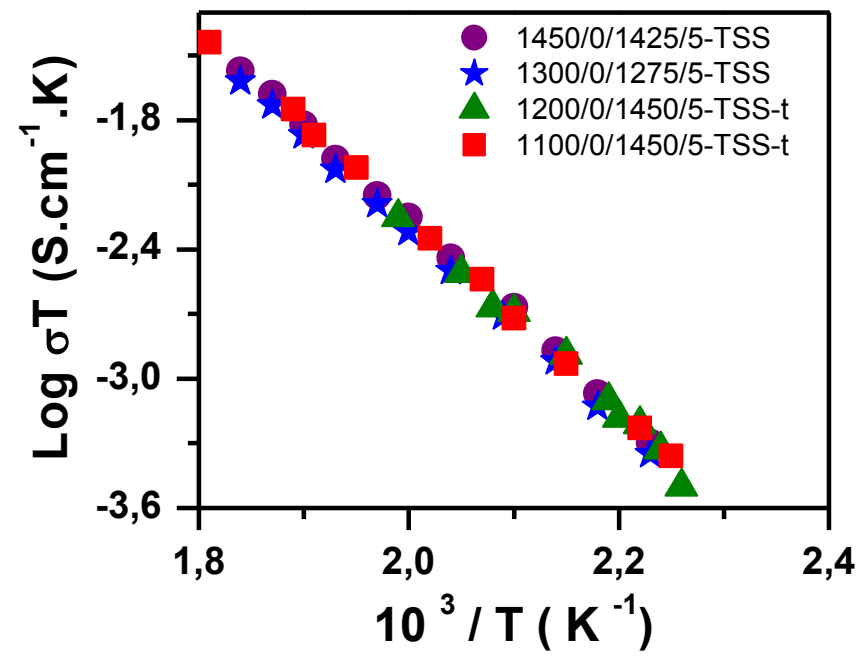

Figura 38: Gráficos de Arrhenius da condutividade elétrica dos grãos das amostras: $1450{ }^{\circ} \mathrm{C} / 0 \mathrm{~h} / 1425^{\circ} \mathrm{C} / 5 \mathrm{~h}$ (TSS), $1300^{\circ} \mathrm{C} / 0 \mathrm{~h} / 1275^{\circ} \mathrm{C} / 5 \mathrm{~h}$ (TSS), $1200{ }^{\circ} \mathrm{C} / 0 \mathrm{~h} / 1450{ }^{\circ} \mathrm{C} / 5 \mathrm{~h}$ (TSS-t) e $1100^{\circ} \mathrm{C} / 0 \mathrm{~h} / 1450{ }^{\circ} \mathrm{C} / 5 \mathrm{~h}$.

Para os grãos variando a temperatura $T_{1}$ ou o método empregado (TSS ou TSS-t) não ocorreu variação da condutividade. Este resultado mostra que a condutividade intragranular (ou dos grãos) é uma característica intrínseca do material, e que estes tratamentos térmicos não alteram a composição química dos grãos significativamente. 


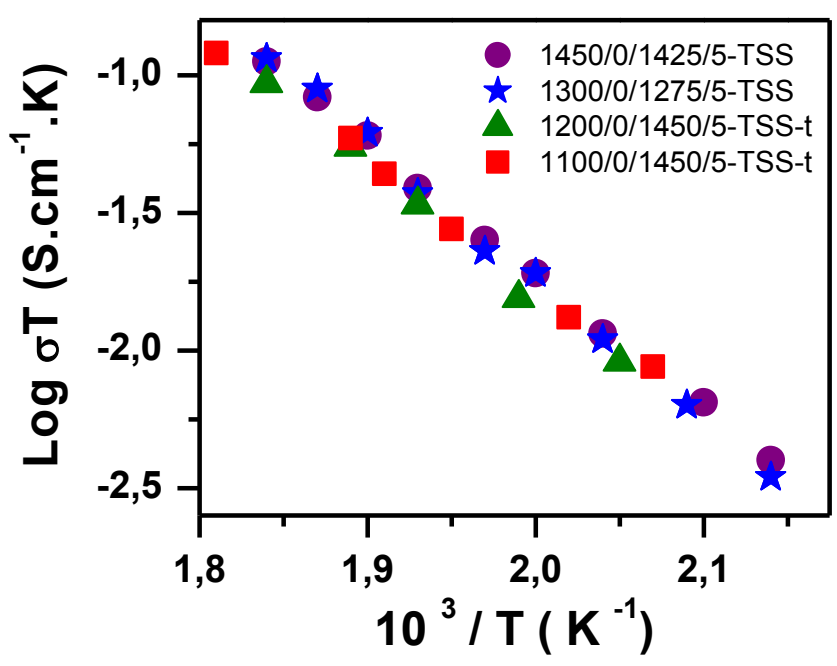

Figura 39: Gráficos de Arrhenius da condutividade elétrica dos contornos de grão das amostras: $1450{ }^{\circ} \mathrm{C} / 0 \mathrm{~h} / 1425{ }^{\circ} \mathrm{C} / 5 \mathrm{~h}$ (TSS), $1300{ }^{\circ} \mathrm{C} / 0 \mathrm{~h} / 1275^{\circ} \mathrm{C} / 5$ $h$ (TSS), $1200{ }^{\circ} \mathrm{C} / 0 \mathrm{~h} / 1450{ }^{\circ} \mathrm{C} / 5 \mathrm{~h}$ (TSS-t) e $1100{ }^{\circ} \mathrm{C} / 0 \mathrm{~h} / 1450{ }^{\circ} \mathrm{C} / 5 \mathrm{~h}$.

Para os contornos de grão, a condutividade elétrica das amostras sinterizadas por ambos os métodos é também similar.

Desta forma, ambos os métodos de sinterização conduzem a valores de condutividade elétrica similares. As diferenças observadas na microestrutura não foram suficientes para causar mudanças significativas na condutividade elétrica.

A tabela $\mathrm{X}$ mostra os valores de energia de ativação do processo de condução para os grãos, contornos e total das amostras sinterizadas pelos dois métodos calculados a partir dos gráficos de Arrhenius. 
Tabela X: Valores de energia de ativação do processo de condução dos grãos $E_{g}$, contornos de grão, $E_{c g}$ e total, $E_{T}$, para amostras TSS com $T_{1}=1300^{\circ} \mathrm{C}$ e $\mathrm{T}_{1}=1450 \stackrel{\circ}{\circ} / 0 \mathrm{~h}$ e diferentes temperaturas $\mathrm{T}_{2}$ e para amostras TSS-t com diferentes temperaturas $\mathrm{T}_{1}$ por $1 \mathrm{~h} \mathrm{e} \mathrm{T}_{2}=1450^{\circ} \mathrm{C} / 5 \mathrm{~h}$.

\begin{tabular}{cccc}
\hline $\begin{array}{c}\text { Condições de } \\
\text { sinterização } \\
\text { o-C/h }\end{array}$ & $\mathbf{E}_{\mathbf{g}}(\mathbf{e V})$ & $\mathbf{E}_{\mathrm{cg}}(\mathbf{e V})$ & $\mathbf{E}_{\mathrm{T}}(\mathbf{e V})$ \\
\hline $1450 / 0$ & 0,89 & 1,02 & 0,88 \\
$1450 / 0+1200 / 5$ & 0,87 & 1,06 & 0,90 \\
$1450 / 0+1300 / 5$ & 0,88 & 0,97 & 0,89 \\
$1450 / 0+1350 / 5$ & 0,89 & 1,11 & 0,95 \\
$1450 / 0+1400 / 5$ & 0,86 & 0,95 & 0,87 \\
$1450 / 0+1425 / 5$ & 0,88 & 0,96 & 0,92 \\
$1300 / 0$ & 0,85 & 1,00 & 0,87 \\
$1300 / 0+1050 / 5$ & 0,87 & 0,98 & 0,90 \\
$1300 / 0+1200 / 5$ & 0,87 & 0,98 & 0,90 \\
$1300 / 0+1250 / 5$ & 0,87 & 1,01 & 0,88 \\
$1300 / 0+1250 / 10$ & 0,88 & 0,96 & 0,91 \\
$1300 / 0+1275 / 5$ & 0,88 & 1,01 & 0,91 \\
$1300 / 0+1275 / 10$ & 0,88 & 1,01 & 0,90 \\
$1000 / 1+1450 / 5$ & 0,89 & 0,97 & 0,89 \\
$1100 / 1+1450 / 5$ & 0,87 & 0,92 & 0,87 \\
$1200 / 1+1450 / 5$ & 0,88 & 0,97 & 0,88 \\
\hline
\end{tabular}

Os valores de energia de ativação para os grãos, contornos e total não variam com as condições de sinterização uma vez que estas não produzem alterações no mecanismo de condução na céria-samária, e são compatíveis com aqueles citados na literatura.

Desta forma, o método de sinterização em duas etapas não se mostrou benéfico tanto para a densificação quanto para a condutividade elétrica da céria-samária. A diminuição no tamanho médio de grãos aliada com a densidade deve, entretanto, resultar em melhorias nas propriedades mecânicas. 


\section{Conclusões}

Os valores de densidade obtidos para amostras preparadas com a solução sólida comercial são sempre superiores aos obtidos para amostras preparadas pela mistura dos óxidos, para uma mesma condição de sinterização.

Valores elevados de densidade só foram obtidos para uma temperatura de pico $\mathrm{T}_{1}$ muito superior a $75 \%$ da densidade teórica. $\mathrm{O}$ método de sinterização em duas etapas não foi efetivo para a densificação da cériasamária sendo que as amostras apresentaram densidade final similar àquela obtida por sinterização tradicional.

As amostras sinterizadas utilizando o método de sinterização em duas etapas tradicional, TSS-t, também atingiram elevados valores de densidade relativa, desde que a temperatura do segundo patamar fosse também elevada.

A estrutura cristalina de todas as amostras é típica da fase fluorita e não foram detectadas fases espúrias para as condições de sinterização empregadas.

Para amostras preparadas com a solução sólida comercial, a sinterização em duas etapas (TSS) proporcionou menor tamanho de grãos quando comparada com a sinterização por duas etapas tradicional (TSS-t).

A condutividade elétrica intragranular independe da forma de sinterização e do perfil temperatura-tempo, nas condições estudadas.

A condutividade elétrica dos contornos de grão nas diferentes amostras foram similares. 


\section{6-REFERÊNCIAS BIBLIOGRÁFICAS}

[1] T. Tsuzuki, P.G. McCormick, J. Am. Ceram. Soc. 84 (2001) 1453.

[2] J. Van Herle, T. Horita, T. Kawada, N. Sakai, H.Yokokawa, M. Dokiya, Solid State lonics 86 (1996) 1255.

[3] Handbook of Chemistry and Physics, David R. Lide (Editor) $87^{\text {Th }}$ Edition CRC Press , Boca Raton (2006-2007).

[4] P. Kofstad, Eletrochemical transport defect - dependent processes. In: P. Kofstad, Nonstoichiometry, Diffusion and Electrical Conductivity in Binary Metal Oxides, Wiley Interscience, USA, (1972).

[5] A. R. West, Solid State Chemistry and its Applications, John Wiley \& Sons, New York (1984).

[6] F. A. Kröger, H. J. Vink, Solid State Physics - Advances in Research and Applications 3 (1956) 307.

[7] H. Inaba, H. Tagawa, Solid State Ionics, 83 (1996) 1.

[8] K. Eguchi, T. Setoguchi, T.Inoue, H. Arai, Solid State lonics 52 (1992) 165.

[9] E. C. C. Souza, Relação Microestrutura-Propriedades do Eletrólito Sólido

$\mathrm{Ce}_{1-\mathrm{x}} \mathrm{Sm}_{\mathrm{x}} \mathrm{O}_{2-\delta}$ preparado a partir de nanopartículas, Tese de Doutorado, IPEN/USP (2008).

[10] S. J. Hong, K. Mehta, A. V. Virkar, J. Electrochem. Soc. 145 (1998) 638.

[11] P. Hagenmuller, W. Van Gool, Eds., Solid Electrolytes: General Principles, Characterization, Materials, Applications, Academic Press (1978).

[12] S. J. Skinner, J. A. Kilner, Oxygen Ion Conductors, Mater. Today 6 (2003) 30.

[13] R. M. German, Sintering, In: Powder Metallurgy Science, edited by K. H. Roll, USA (1984).

[14] R. M. German, Sintering Theory and Practice, John Wiley \& Sons, New York (1996).

[15] A. G. P. Silva, C. Alves Júnior, Cerâmica 44 (1998) 289.

[16] W. D. Callister, Materials Science and Engineering - an Introduction, John Wiley \& Sons, INC, $3^{\text {rd }}$ Edition, USA (1994).

[17] A. Koller, Materials Science Monographs, Structure and Properties of Ceramics, Elsevier, Czech Republic 80 (1994) 114.

[18] M. F. Ashby, Acta Metall. 22 (1974) 255. 
[19] S.-J L. Kang, Sintering Densification, Grain Growth \& Microstructure, Elsevier Burlington (2005).

[20] R. L. Coble, J. Appl. Phys. 40 (1969) 793.

[21] I.-W. Chen, X.-W. Wang, Nature 404 (2000) 168.

[22] Ceramic Processing and Sintering, $2^{\text {nd }}$ Edition, M. N. Rahaman, CRC Press, 2003, Boca Raton, USA.

[23] M. -Y. Chu, L. C. Jonghe, J. Am. Ceram. Soc. 74 (1991) 2902.

[24] F. J. T. Lin, L. C. Jonghe, M. N. Rahaman, J. Am. Ceram. Soc. 80 (1997) 2269.

[25] F. J. T. Lin, L. C. Jonghe, M. N. Rahaman, J. Am. Ceram. Soc. 80 (1997) 2891.

[26] Y.-I. Lee, Y.-W. Kim, M. Mitomo, D.-Y. Kim, J. Am. Ceram. Soc. 86 (2003) 1803.

[27] Y.-I. Lee, Y.-W. Kim, M. Mitomo, D.-Y. Kim, J. Mater. Sci. 39 (2004) 3801.

[28] H. T. Kim, Y., H. Han, Ceram. Int. 30 (2004) 1719.

[29] A. Polotai, K. Breece, E. Dickey, C. Randall, A. Ragulya, J. Am. Ceram. Soc. 88 (2005) 3008.

[30] X. -H. Wang, X. -Y. Deng, Hai-Lin Bai, H. Zhou, Wei-Guo Qu, L. -T.Li, I. W. Chen, J. Am. Ceram. Soc., 89 (2006) 438.

[31] X. -H Wang, Pei-Lin Chen, I -W. Chen, J. Am. Ceram. Soc. 89 (2006) 431. [32] H.-D. Kim, Y.-J. Park, B.-D. Han, M.-Q. Park, W.-T. Bae, Y.-W. Kim, H.-T. Lin, P. F. Becher, Scripta Mater. 54 (2006) 615.

[33] J. Li, Y. Ye, J. Am. Ceram. Soc. 89 (2006) 139.

[34] K. Bodisová, P, Sajgalik, D. Galusek, P. Svancarek, J. Am. Ceram. Soc. 90 (2007) 330.

[35] Z. R. Hesabi, M. Haghighatzadeh, M. Mazaheri, D. Galusek, S. K. Sadrnezhaad, J. Eur. Ceram. Soc. 29 (2009) 1371.

[36] C. L. -Robert, F. Ansart, C. Deloget, M. Gaudon, A. Rousset, Ceram. Int. 29 (2003) 151.

[37] M. Han, X. Tang, H. Yin, S. Peng, J. Power Sources 165 (2007) 757.

[38] A. Ghosh, A. K. Suri, B. T. Rao, T. R. Ramamohan, J. Am. Ceram. Soc 90 (2007) 2015.

[39] M. Mazaheri, M. Valefi, Z. R. Hesabi, S. K. Sadrnezhaad, Ceram. Int. 35 (2009) 13. 
[40] M. Mazaheri, Z. R. Hesabi. F. G. -Fard, S. Mollazadeh, S. Jafari, S. K. Sadrnezhaad, J. Am. Ceram. Soc. 92 (2009) 990.

[41] Z. R. Hesabi, M. Mazaheri, T. Ebadzadeh, J. Alloy. Compd. 494 (2010) 362.

[42] E. N. S. Muccillo, R. Muccillo, $217^{\text {th }}$ Meeting of the Electrochemical Society, Ionic and Mixed Conducting Ceramics 7, 26-30 April, 2010, Vancouver, Canadá.

[43] M. Mazaheri, A. M. Zahedi, S. K. Sadrnezhaad, J. Am. Ceram. Soc. 91 (2008) 56.

[44] M. Mazaheri, Z. R. Hesabi, S. K. Sadrnezhaad, Scripta Mater. 59 (2008) 139.

[45] Z. Li, Z. Li, A. Zhang, Y. Zhu, J. Sol-Gel Sci. Technol. 48 (2008) 283.

[46] J. Binner, K. Annapoorani, A. Paul, I. Santacruz, B. Vaidhyanathan, J. Eur. Ceram. Soc. 28 (2008) 973.

[47] J. Binner, B. Vaidhyanathan, J. Eur. Ceram. Soc. 28 (2008) 1329.

[48] P. C. Yu, Q. F. Li, J. Y. H. Fuh, T. Li, L. Lu, J. Mater. Processing Technol. 192 (2007) 312.

[49] A. Ghosh, G. K. Dey, A. K. Suri, J. Am. Ceram. Soc. 91 (2008) 3768.

[50] M. Mazaheri, A. Simchi, F. G. -Fard, J. Eur. Ceram. Soc. 28 (2008) 2933.

[51] S. H. Jo, P. Muralidharan, D. K. Kim, Solid State Ionics 178 (2008) 1990.

[52] A. Rafferty, T. Prescott, D. Brabazon, Ceram. Int. 34 (2008) 15.

[53] C. M. Lapa, D. P. Ferreira de Souza, F. M. L. Figueiredo, F. M. B. Marques, J. Power Sources 187 (2009) 204.

[54] K. Maca, V. Pouchly, P. Zalud, J. Eur. Ceram. Soc. 30 (2010) 583.

[55] G.S. Godoi, D.P.F. de Souza, Solid State lonics 180 (2009) 1587.

[56] M. Ionashiro, Princípios Básicos da Termogravimetria e Análise Térmica Diferencial/ Calorimetria Exploratória Diferencial, Araraquara (2004).

[57] A. F. Padilha, F. Ambrozio F, Técnicas de Análise Microestrutural; ed. Hemus (1985).

[58] R. F. Speyer, Thermal Analysis of Materials; ed. Marcel Dekker Inc; New York (1993).

[59] B. D. Cullity, Elements of X-Ray Diffraction, $2^{\text {nd }}$ Edition, Addison-Wesley Co., Massachussets (1978). 
[60] H. J. Kestenbach, W. J. Botta Filho, Microscopia Eletrônica - Transmissão e Varredura, Assoc. Bras. de Metais, São Paulo, (1989).

[61] M. J. Mendelson, J. Am. Ceram. Soc. 52 (1969) 443.

[62] J. E. Bauerle, J. Phys. Chem. Solids 30 (1969) 443.

[63] JCPDS\#28792

[64] S. L. Reis, E. C. C. Souza, E. N. S. Muccillo, Solid State Ionics, DOI: 10.1016/j.ssi.2010.06.017. 